$$
f-3393
$$

ORNL/TM-7190

\title{
A Source Book for Planning Nuclear Dual-Purpose Electric/Distillation Desalination Plants
}

\author{
S. A. Reed
}

\section{MASTER}

OPERATED BY

UNION CARBIDE CORPORATION

FOR THE UNITED STATES

DEPARTMENT OF ENERGY 


\section{DISCLAIMER}

This report was prepared as an account of work sponsored by an agency of the United States Government. Neither the United States Government nor any agency Thereof, nor any of their employees, makes any warranty, express or implied, or assumes any legal liability or responsibility for the accuracy, completeness, or usefulness of any information, apparatus, product, or process disclosed, or represents that its use would not infringe privately owned rights. Reference herein to any specific commercial product, process, or service by trade name, trademark, manufacturer, or otherwise does not necessarily constitute or imply its endorsement, recommendation, or favoring by the United States Government or any agency thereof. The views and opinions of authors expressed herein do not necessarily state or reflect those of the United States Government or any agency thereof. 


\section{DISCLAIMER}

Portions of this document may be illegible in electronic image products. Images are produced from the best available original document. 


\section{Printed in the United States of America. Available from National Technical Information Service \\ U.S. Department of Commerce 5285 Port Royal Road, Springfield, Virginia 22161 NTIS price codes-Printed Copy: A06 Microfiche A01}

This report was prepared as an account of work sponsored by an agency of the United States Government. Neither the United States Government nor any agency thereof, nor any of their employees, makes any warranty, express or implied, or assumes any legal liability or responsibility for the accuracy, completeness, or usefulness of any information, apparatus, product, or process disclosed, or represents that its use would not infringe privately owned rights. Reference herein to any specific commercial product, process, or service by trade name, trademark, manufacturer, or otherwise, does not necessarily constitute or imply its endorsement, recommendation, or favoring by the United States Government or any agency thereof. The views and opinions of authors expressed herein do not necessarily state or reflect those of the United States Government or any agency thereof. 


\title{
A SOURCE BOOK FOR PLANNING NUCLEAR DUAL-PURPOSE ELECTRIC/DISTILLATION DESALINATION PLANTS
}

\author{
S. A. Reed
}

Date Published: February 1981

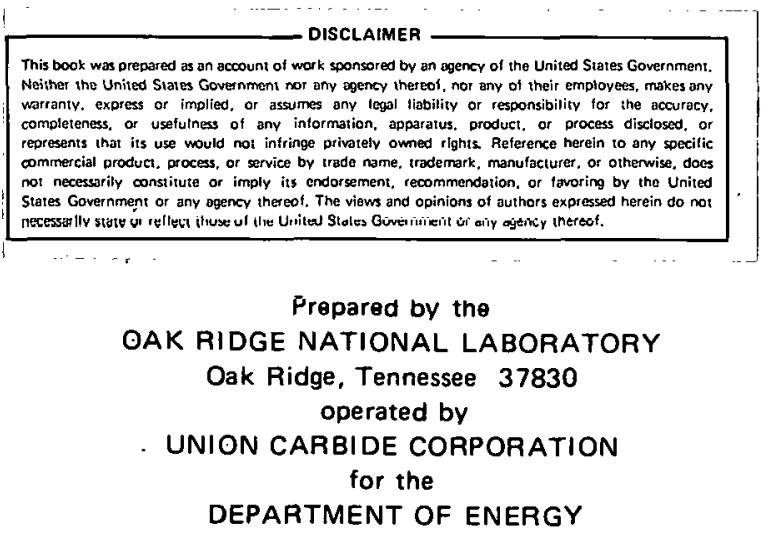




\section{THIS PAGE}

\section{WAS INTENTIONALLY \\ LEFT BLANK}




\section{CONTENTS}

Page
PBSTRACT $\ldots \ldots \ldots \ldots \ldots \ldots \ldots \ldots \ldots \ldots \ldots \ldots \ldots \ldots \ldots \ldots$

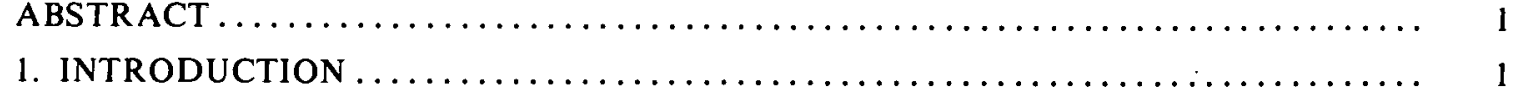

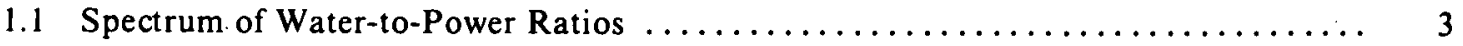

2. COMMERCIAL NUCLEAR PLANTS $\ldots \ldots \ldots \ldots \ldots \ldots \ldots \ldots \ldots \ldots \ldots \ldots \ldots \ldots$

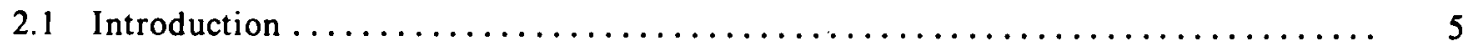

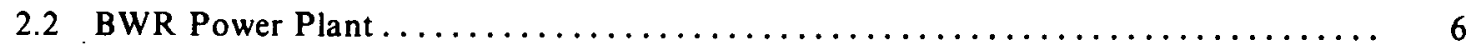

2.2 .1 Nuclear steam system $\ldots \ldots \ldots \ldots \ldots \ldots \ldots \ldots \ldots \ldots \ldots \ldots \ldots \ldots \ldots \ldots \ldots \ldots \ldots$

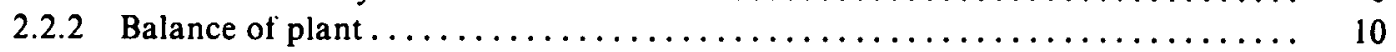

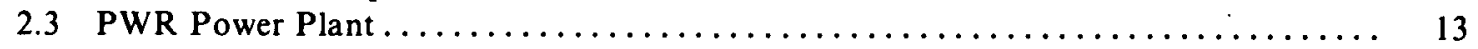

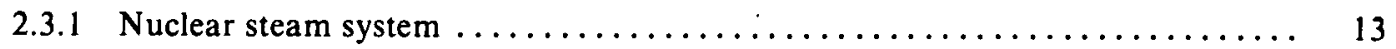

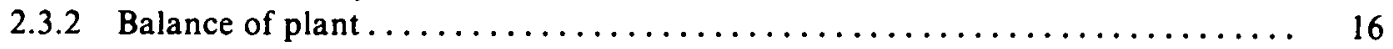

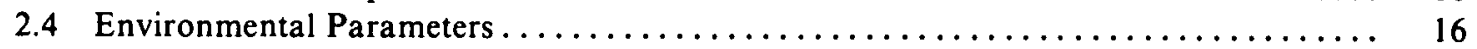

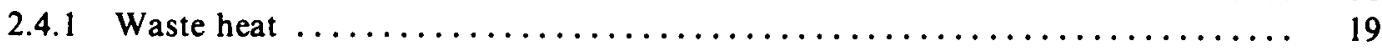

2.4 .2 Radiological ................................... 19

2.5 Operating and Maintenance Manpower Needs . . . . . . . . . . . . . . . . . 20

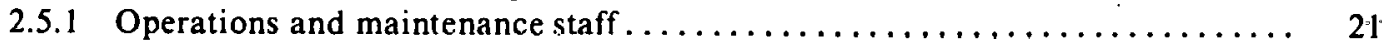

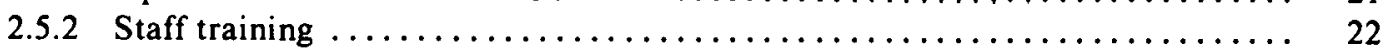

2.6 Downtime for Refueling and Other Maintenance .................... 24

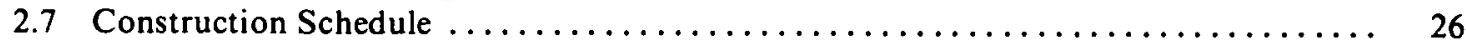

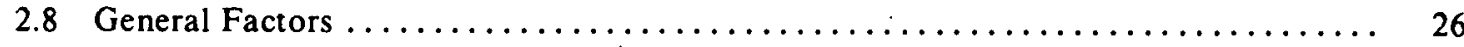

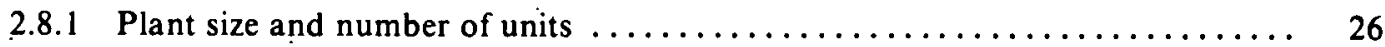

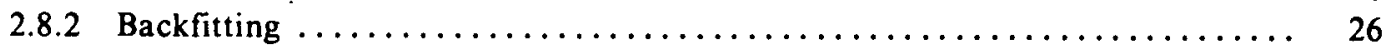

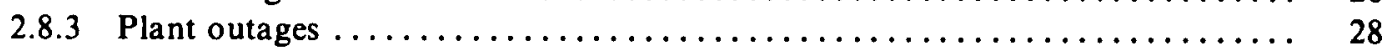

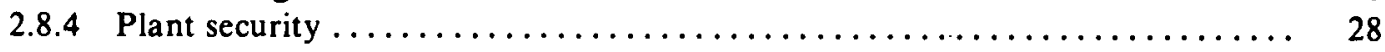

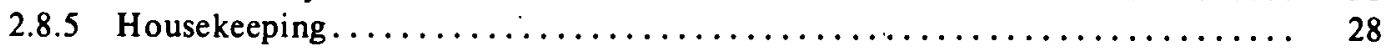

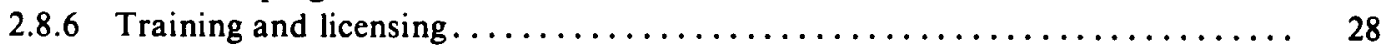

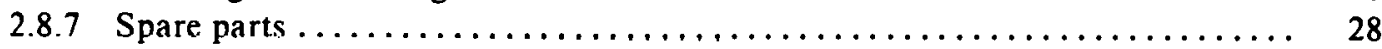

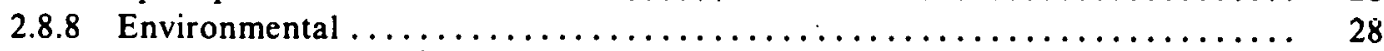

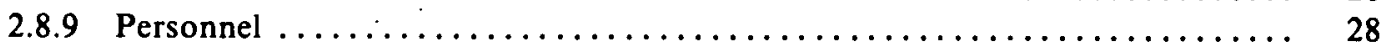

2.8.10 Occupational Safety and Health Administration

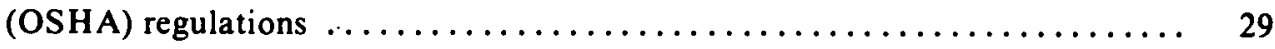

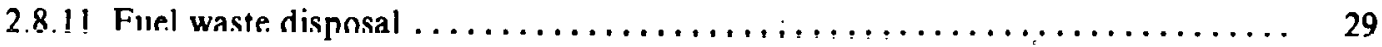

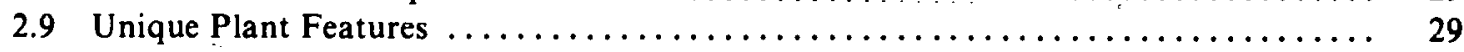

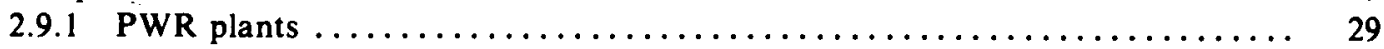

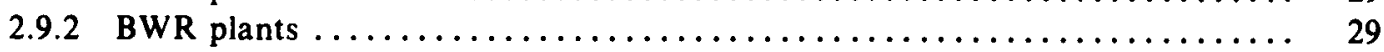

2.10 Nuclear Plant Costs................................. 30

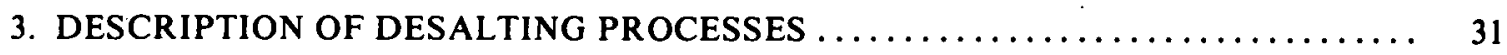

3.1 Multistage Flash (MSF) Evaporation Process $\ldots \ldots \ldots \ldots \ldots \ldots \ldots \ldots \ldots \ldots \ldots \ldots$

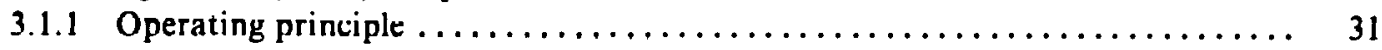

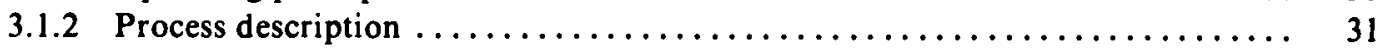

3.2 Vertical Tube Evaporation (VTE) Process $\ldots \ldots \ldots \ldots \ldots \ldots \ldots \ldots \ldots \ldots \ldots \ldots \ldots \ldots \ldots$

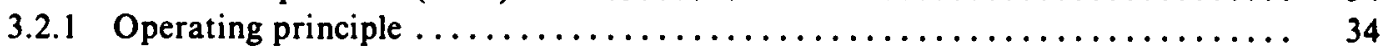

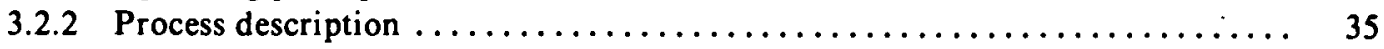

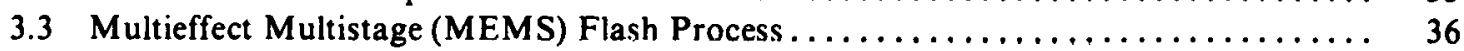

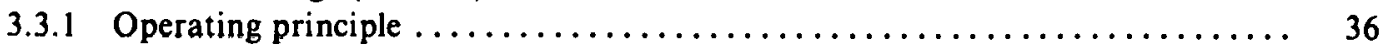

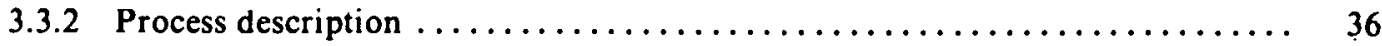


4. SEAWATER PRETREATMENT $\ldots \ldots \ldots \ldots \ldots \ldots \ldots \ldots \ldots \ldots \ldots \ldots \ldots \ldots \ldots \ldots \ldots \ldots$

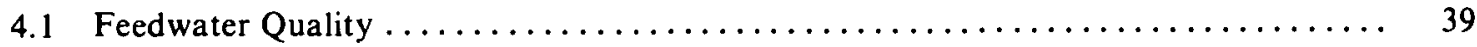

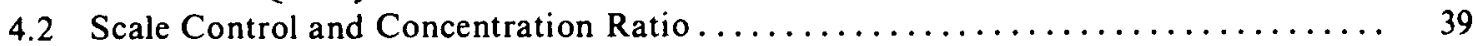

4.3 Corrosion Control ................................... 41

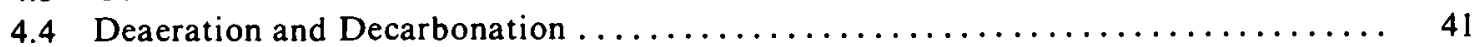

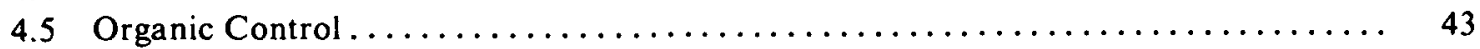

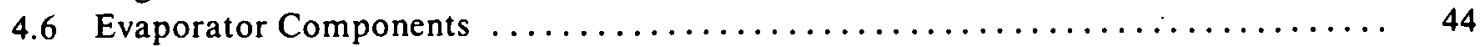

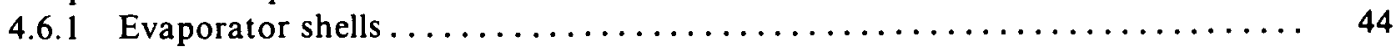

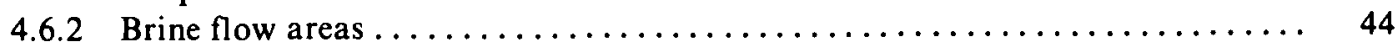

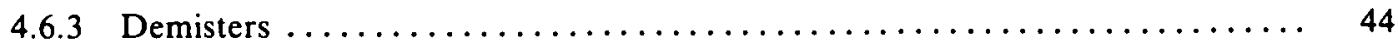

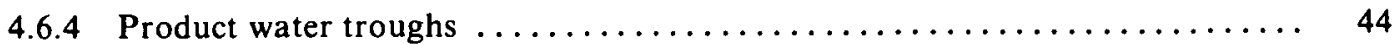

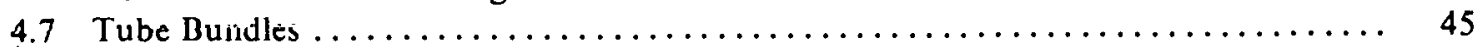

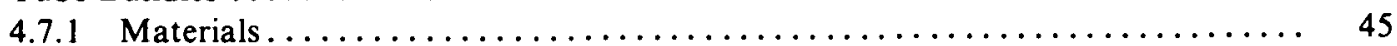

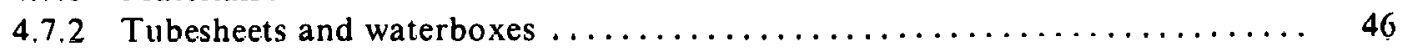

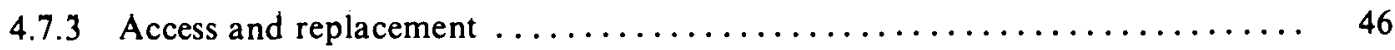

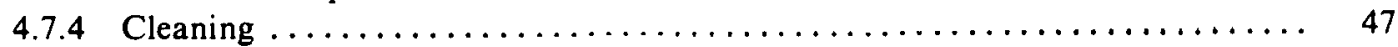

4.8 Brine Kecirculation Pumps and Drivers $\ldots \ldots \ldots \ldots \ldots \ldots \ldots \ldots \ldots \ldots \ldots \ldots \ldots \ldots \ldots$

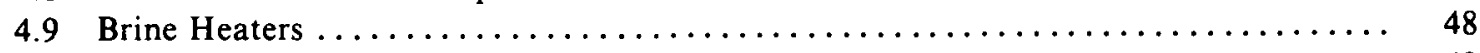

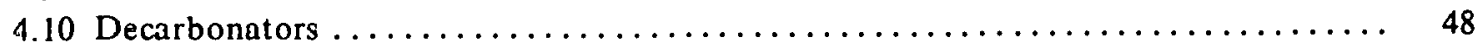

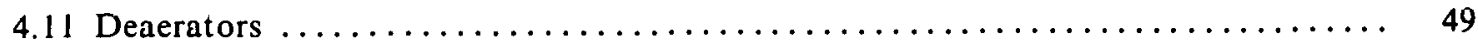

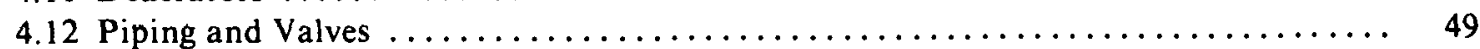

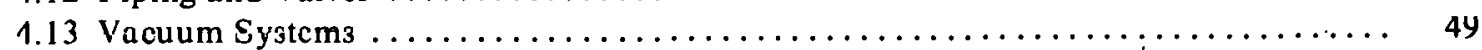

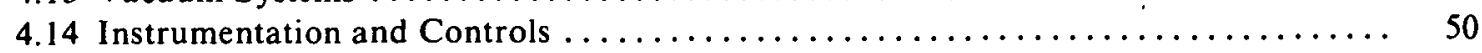

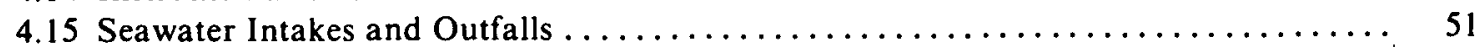

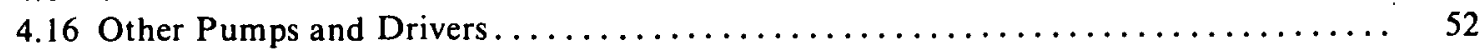

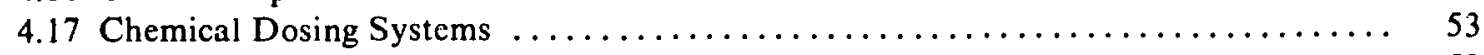

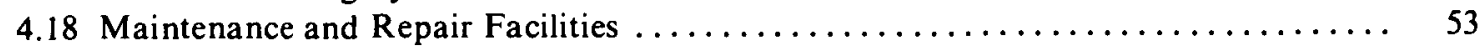

4.19 Staffing Requirements $\ldots \ldots \ldots \ldots \ldots \ldots \ldots \ldots \ldots \ldots \ldots \ldots \ldots \ldots \ldots \ldots \ldots \ldots \ldots \ldots \ldots$

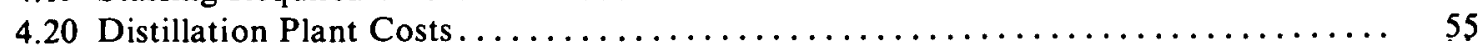

5. COUPLING AND CONTROL REQUIREMENTS FOR LARGE

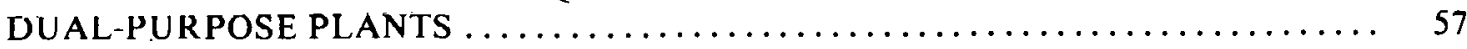

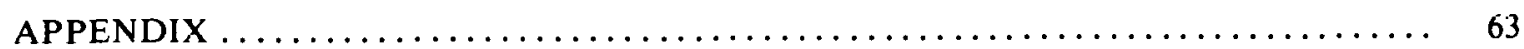

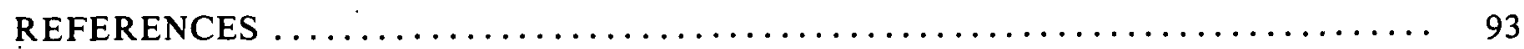




\title{
A SOURCE BOOK FOR PLANNING NUCLEAR DUAL-PURPOSE ELECTRIC/DISTILLATION DESALINATION PLANTS
}

\author{
S. A. Reed
}

\begin{abstract}
A source book on nuclear dual-purpose electric/distillation desalination plants was prepared to assist government and other planners in preparing broad evaluations of proposed applications of dual-purpose plants. The document is divided into five major sections. Section 1 presents general discussions relating to the benefits of dual-purpose plants, and spectrum for water-to-power ratios. Section 2 presents information on commercial nuclear plants manufactured by U.S. manufacturerș. Section 3 gives information on distillation desalting processes and equipment. Section 4 presents a discussion on feedwater pretreatment and scale control. Section 5 deals with methods for coupling the distillation and electrical generating plants to operate in the dual mode.
\end{abstract}

\section{INTRODUCTION}

A dual-purpose plant is one which produces both power and desalted water with the optimum use of thermal energy in producing the two products. Figure 1 illustrates the dual-purpose plant concept. Prime steam at high temperature and pressure is supplied to the turbine, where it is expanded to produce electrical power. At the much lower condition of temperature and pressure appropriate for the evaporator plant, the steam is exhausted from the turbine and used to provide heat for the evaporator. The steam condensate passes through feed heaters, as in any power plant cycle, and returns to the steam supply for recycle.

There are three economic-advantages of the dual-purpose plant. The first, and by far the most important, is the thermodynamic effect. This can be illustrated quite simply by considering the thermal power required and the waste heat exhausted in producing power and water from separate singlepurpose plants vs a single dual-purpose plant. Figure 2 illustrates this comparison. First, considering the single-purpose power plant, to produce $1000 \mathrm{MW}(\mathrm{e})$ requires $3000 \mathrm{MW}(\mathrm{t})$ of energy. T' he remaining $2000 \mathrm{MW}$ are exhausted as low temperature waste heat. To produce $1135 \times 10^{3} \mathrm{~m}^{3} / \mathrm{d}(300 \mathrm{Mgd})$ of desalted water in a single-purpose plant requires about $3000 \mathrm{MW}(\mathrm{t})$, all of which ultimately is discharged as low temperature waste heat. The sum total of the two separate single-purpose plants requires $6000 \mathrm{MW}(\mathrm{t})$ and exhausts $5000 \mathrm{MW}(\mathrm{t})$ to the atmosphere as waste heat. 


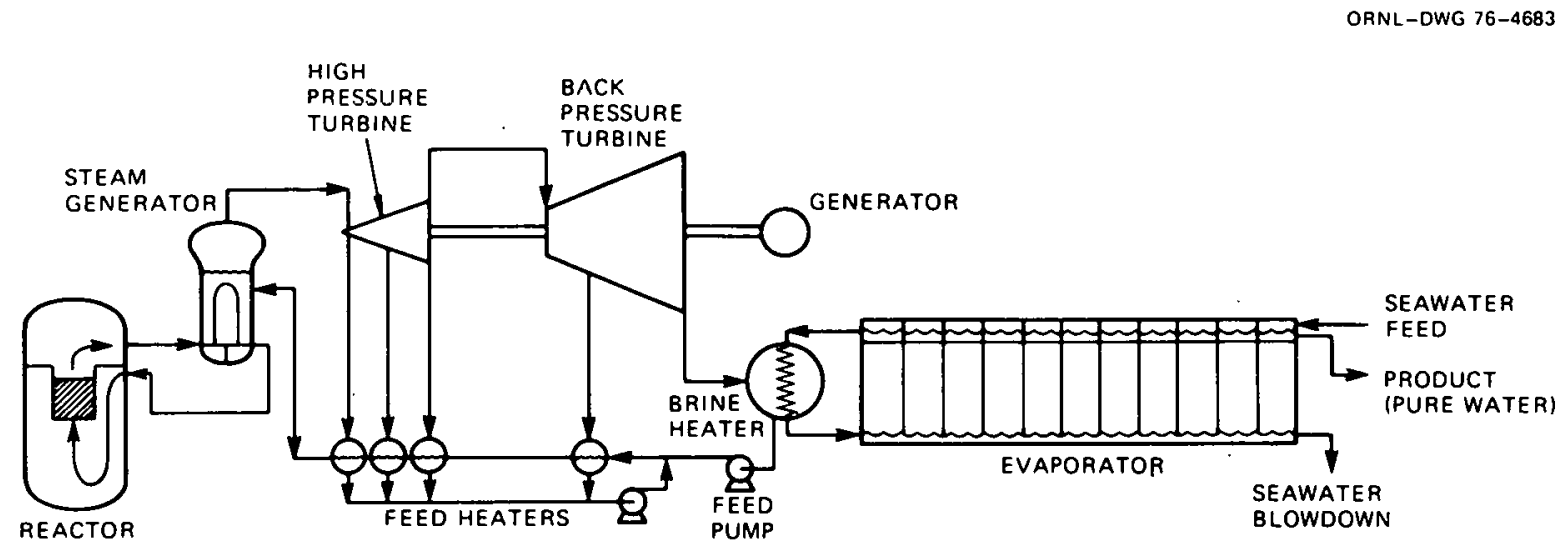

Fig. 1. Dual-purpose plàit cinutepul.

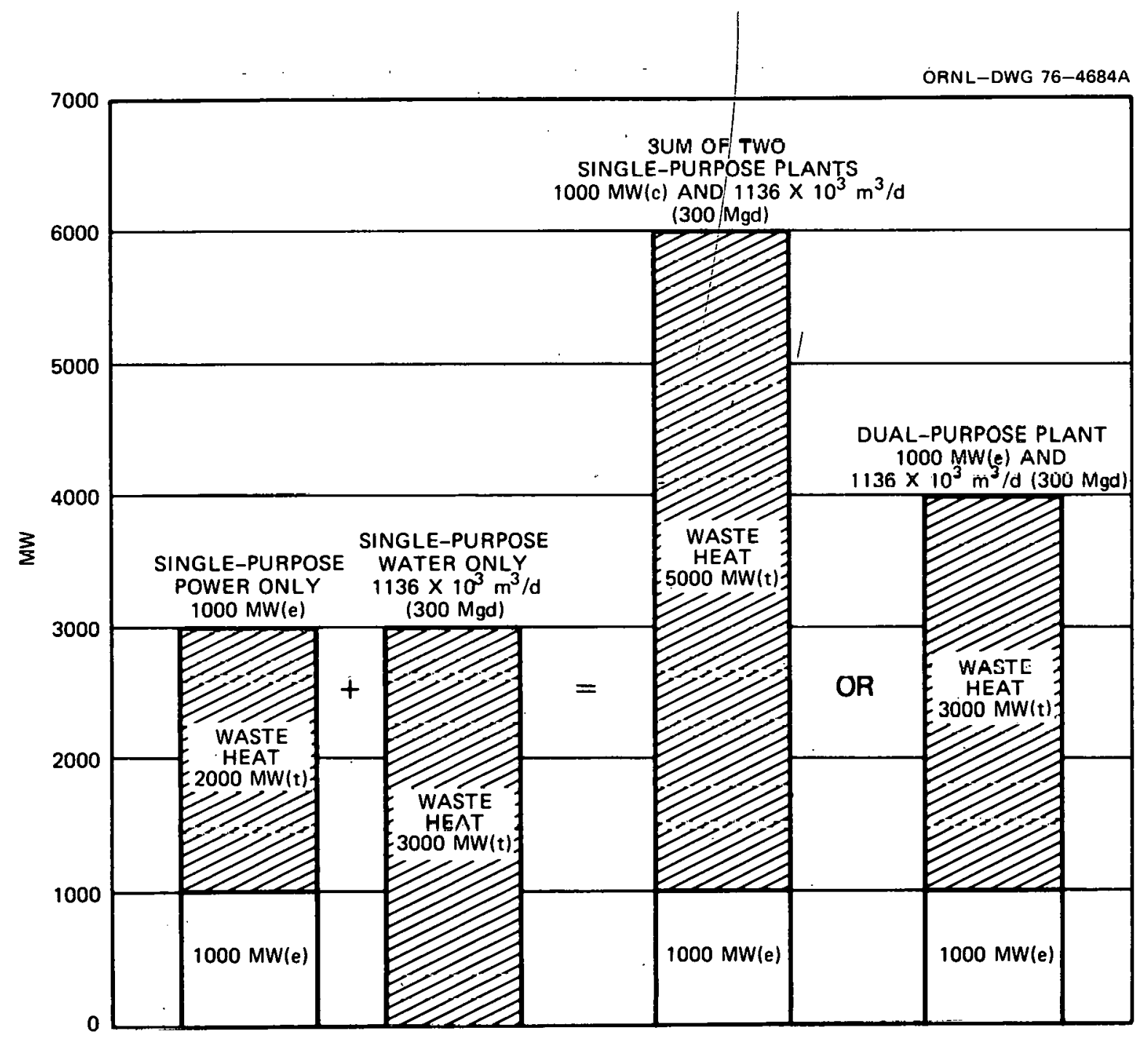

Fig. 2. Thermodynamic effect-comparison of single- and dual-purpose plants. 
Now, consider a dual-purpose plant to produce these same two products, $1000 \mathrm{MW}(\mathrm{e})$ and I $135 \mathrm{X}$ $10^{3} \mathrm{~m}^{3} / \mathrm{d}(300 \mathrm{Mgd})$ of water. The total energy required in this case is $4000 \mathrm{MW}(\mathrm{t})$, and the total waste heat exhausted is $3000 \mathrm{MW}(\mathrm{t})$. Thus a savings in energy generation of $2000 \mathrm{MW}(\mathrm{t})$ is realized, and the exhaust heat load is reduced from $5000 \mathrm{MW}(\mathrm{t})$ to $3000 \mathrm{MW}(\mathrm{t})$.

The second advantage results from the size effect for the energy source. For either nuclear or fossil , plants, there is a decrease in unit capital cost as size increases. By combining the two products in a dual-purpose plant, the size of the steam supply is increased and the unit cost of the steam is less.

The third advantage results from shared facilities in the dual-purpose plant, such as intakes and outfalls. Certain components, shop areas, and service areas with slight increases in size can serve both facilities. Also, certain staff personnel can be shared between the facilities. This results in an overall savings in the dual-purpose plant.

\subsection{Spectrum of Water-to-Power Ratios}

Within the general concept of dual-purpose plants, there are wide variations of such plants, and each variation has its own peculiar requirements relative to coupling arrangements and control systems. The following discussion shows the range of choices possible.

The spectrum of conceivable plant designs, as characterized by design-point product ratios, is shown in Fig. 3. The hardware variations associated with various product ratios are indicated. Although nuclear heat sources are illustrated, the design options are equally valid for fossil energy sources. The "balanced" plants are most truly representative of the dual-purpose concept, because all of the heat given up at the turbine exhaust furnishes all of the heat input to the water plant. Plants of lower water-to-power ratio would utilize extraction steam or parallel back-pressure and condensing turbines to produce the desired lesser water outputs. Others make use of the extraction steam alternative. In either of these cases, the water plant could be shut down entirely without materially affecting the total plant power output. At the opposite end of the product-ratio spectrum are plants utilizing steam bypass around the turbine, or vapor compression cycles, to produce high ratios of water to power.

The question of how much water and how much power a plant should produce is not one that can be answered by simply examining the characteristics of dual-purpose plants; consideration must be given to the projected market for the products, elasticity of the market, and alternative means of meeting the needs. 


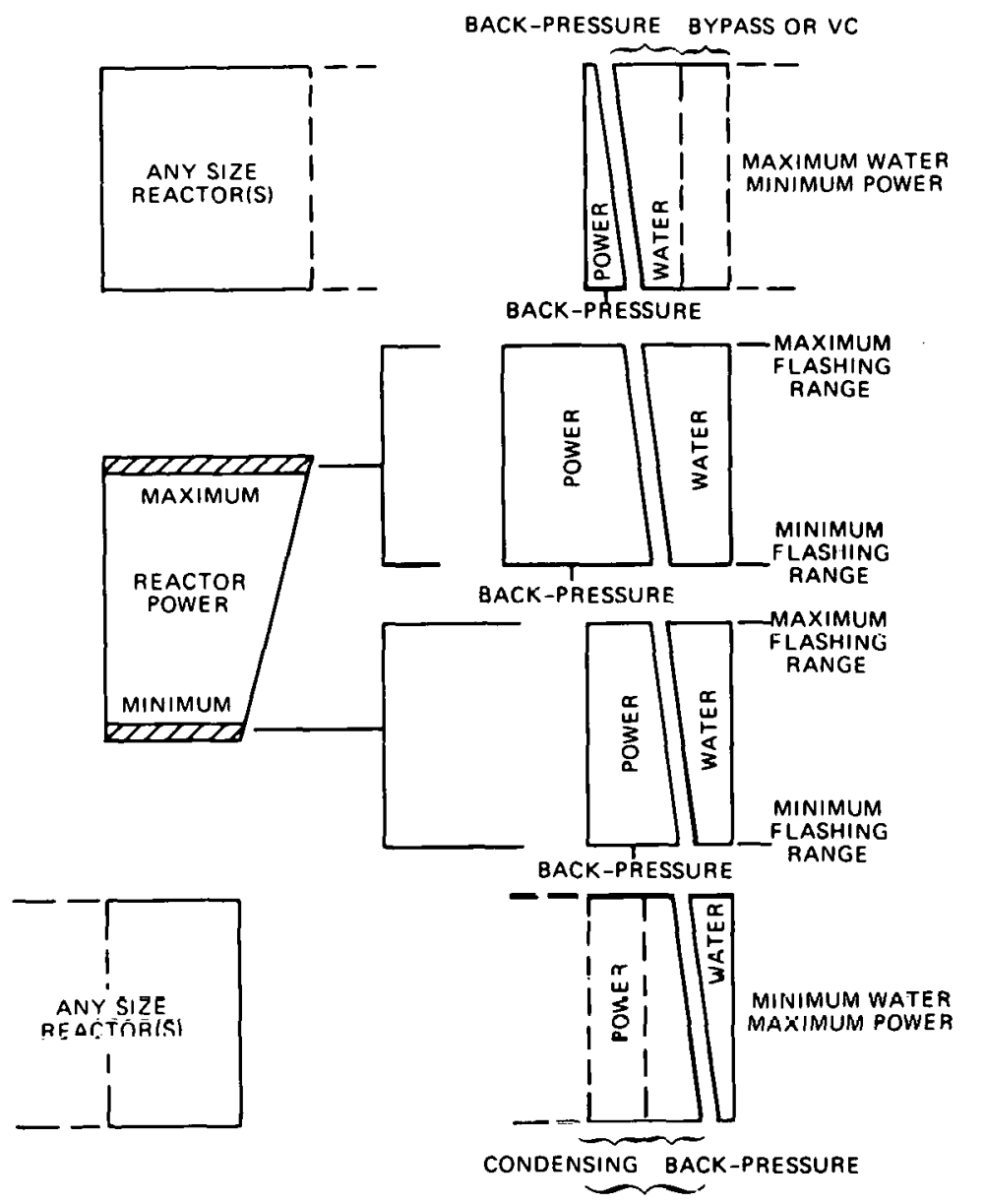

"BALANCED" DUAL-PURPOSE PLANTS

ESSENTIALLY ALL OF THE STEAM IS USEO IN SERIES IN THE BACK-PRESSURE TURBINE AND THE WATER PLANT, WITH NO BYPASS AND NO CONDENSING TURBINE. A LIMITED RANGE OF POWER-TO-PRUDUCT RATIOS IS OBTAINED BY VARYING THE FLASHING RANGE (MAXIMUM BRINE TEMPERATURE), OR POSSIBLY WITH VARIABLE ORIFICES. TOTAL OUTPUT VARIES WITH REACTOR POWER.

\section{EXTRACTION OR DUAL TURBINES}

A CONDENSING TRUBINE IS USEO, WITH EXTRACTION STEAM FURNISHING MEAT TO THE WATER PLANT. ALTERNATIVELY. A BACK-PRESSURE TURBINE MIGHT BE USED IN PARALLEL WITH A CONOENSING ONE, DEPENDING ON THE ECONOMICS AND DESIGN REQUIREMENTS OF SPECIFIC CASES.

Fig. J. Kange ôt dual-purpose plant product ratios. 


\section{COMMERCIAL NUCLEAR PLANTS}

\subsection{Introduction}

Commercial U.S. nuclear plants presently available are boiling water and pressurized water reactors (BWRs and PWRs). Both BWRs and PWRs use slightly enriched uranium dioxide pellets as fuel and demineralized water as coolant and moderator.

With one exception, all large nuclear plants in the United States are single-purpose electricitygenerating plants. Unit 1 of the Consumers Power Midland Plant is designed both to generate. electricity and to produce process steam for the Dow Chemical Company at Midland, Michigan. The reactor plant for unit 1 will generate $1285 \mathrm{~kg} / \mathrm{s}(10,200,000 \mathrm{lb} / \mathrm{h})$ of prime steam. Of this amount, 50.4 $\mathrm{kg} / \mathrm{s}(400,000 \mathrm{lb} / \mathrm{h})$ will be used to generate high-pressure process steam at $4137 \mathrm{kPa}(600 \mathrm{psi})$ and 1235 $\mathrm{kg} / \mathrm{s}(9,800,000 \mathrm{lb} / \mathrm{h})$ will be delivered to the turbine throttle. Turbine extraction steam will be used to generate $460 \mathrm{~kg} / \mathrm{s}(3,650,000 \mathrm{lb} / \mathrm{h})$ of low-pressure extraction steam at $862 \mathrm{kPa}(125 \mathrm{psi})$. Unit 2 will be a single-purpose electricity-generating plant.

Standard reactor sizes available range from about $550 \mathrm{MW}(\mathrm{e})[1862 \mathrm{MW}(\mathrm{t})]$ to $1300 \mathrm{MW}(\mathrm{e})[3817$ $M W(t)]$. Overall plant efficiencies are about $33 \%$ for the PWR and the BWR.

The commercial BWR was developed and is marketed by the General Electric Company. Dresden 1, the forerunner of the large BWR, is owned and operated by Commonwealth Edison Company. Commercial service began in August 1960 and the rated capability of 200 MW(e) was reached in 1962.

As shown in Table 2.1, General Electric is currently marketing the BWR-6 nuclear steam system in three standard sizes.

Table 2.1. General Electric nominal plant ratings

\begin{tabular}{lrrr}
\hline Fuel assemblies & 624 & 748 & 864 \\
Thermal power, MW(t) & 2894 & 3579 & 3800 \\
Electrical power, MW(e) & 985 & 1217 & 1287 \\
Steam pressure M Pa, (psia) & 6.65 (965) & $6.65(965)$ & $6.65(965)$ \\
Efficiency (\%) & 34 & 34 & 33.9 \\
\hline
\end{tabular}

The first commercial PWR nuclear steam system was developed and marketed by Westinghouse Electric Corporation. Westinghouse and Duquesne Light Company started construction of the demonstration PWR power plant (Shippingport) in March 1955. This plant reached its full rated power of $150 \mathrm{MW}(\mathrm{e})$ in December 1957. Combustion Engineering, Inc., and Rahcock and Wilcox Company are now also marketing commercial PWR nuclear steam systems. Both the Westinghouse and 
Combustion Engineering systems produce saturated steam using U-tube steam generators, while Babcock and Wilcox systems produce slightly superheated steam using a once-through steam generator.

The Babcock and Wilcox nuclear steam system utilizes two coolant loops, each of which contains a steam generator and two primary coolant pumps. Table 2.2 lists the three sizes of these units presently being marketed.

Table 2.2. Babcock and Wilcox nominal plant ratings

\begin{tabular}{lrrr}
\hline Fuel assemblies & 177 & 205 & 205 \\
Thermal power, MW(t) & 2943 & 3600 & 3800 \\
Electrical power, MW(e) & 1022 & 1237 & 1296 \\
Steam pressure M Pa, (psia) & $7.31(1060)$ & $7.31(1060)$ & $7.31(1060)$ \\
Effioiency (\%) & .34 .7 & 34.4 & 34.1 \\
\hline
\end{tabular}

Combustion Engineering manufactures a nuclear steam system with two coolant loops, each with a steam geiteratur and two reactor coolant pumps. Characteristics are given in Table 2.3.

\begin{tabular}{lc}
$\begin{array}{c}\text { Table 2.3. Combustion Enginecring } \\
\text { nominal plant ratings }\end{array}$ \\
\hline Fuel assemblies & 241 \\
Thermal power, MW(t) & 3817 \\
Elect rical power, MW(e) & 1300 \\
Steam pressure MPa. (psig) & $7.38(1070)$ \\
Efficiency (\%) & 34
\end{tabular}

Westinghouse offers standard nuclear steam system designs with twn, three, and four coolant loops. Current ratings are given in Table 2.4. The twn-Innp system is not available in the United Statcs but is marketed abroad.

Table 2.4. Westinghouse nominal plant ratings

\begin{tabular}{|c|c|c|c|c|}
\hline Number of loope & 2 & 3 & 4 & 4 \\
\hline rucl assemblies & 121 & $\left|s^{\prime}\right|$ & 193 & 193 \\
\hline Thermal power; $M W(t)$ & 1862 & 2775 & 3411 & 3820 \\
\hline Electrical power, $M W(e)$ & 600 & 900 & 150 & 1300 \\
\hline Steum pressurc MPa, (psia) & $6.34(920)$ & $6.65(964)$ & $6.90(1000)$ & $7.57(1100)$ \\
\hline Efficienoy ( $\pi$ ) & 32.2 & 32.4 & 33.1 & 34.0 \\
\hline
\end{tabular}

\subsection{BWR Power Plant}

\subsubsection{Nuclear steam system}

The nuclear steam system includes a direct-cycle, forced circulation BWR that produces steam in the core for direct use in the steam turbine. A diagram showing the major parameters of the nuclear system for the rated power conditions of $3579 \mathrm{MW}(\mathrm{t})$ is shown in Fig. 4. Design characteristics of the system are shown in Table 2.5 . 
ORNL-DWG 74-5698A

\begin{tabular}{|l}
\hline LEGEND \\
$\#=$ FLOW \\
$F=$ TEMPERATUAE $\left({ }^{\circ} \mathrm{F}\right)$ \\
$H, h=$ ENTHALPY (Btu/lb) \\
$M=$ \% MOISTURE \\
$P=$ PRESSURE (Paia) \\
$D=$ ISOLATION VALVES
\end{tabular}

\begin{tabular}{l} 
ASSUMED SYSTEM LOSSES \\
THEAMAL 1.1 \\
\hline
\end{tabular}

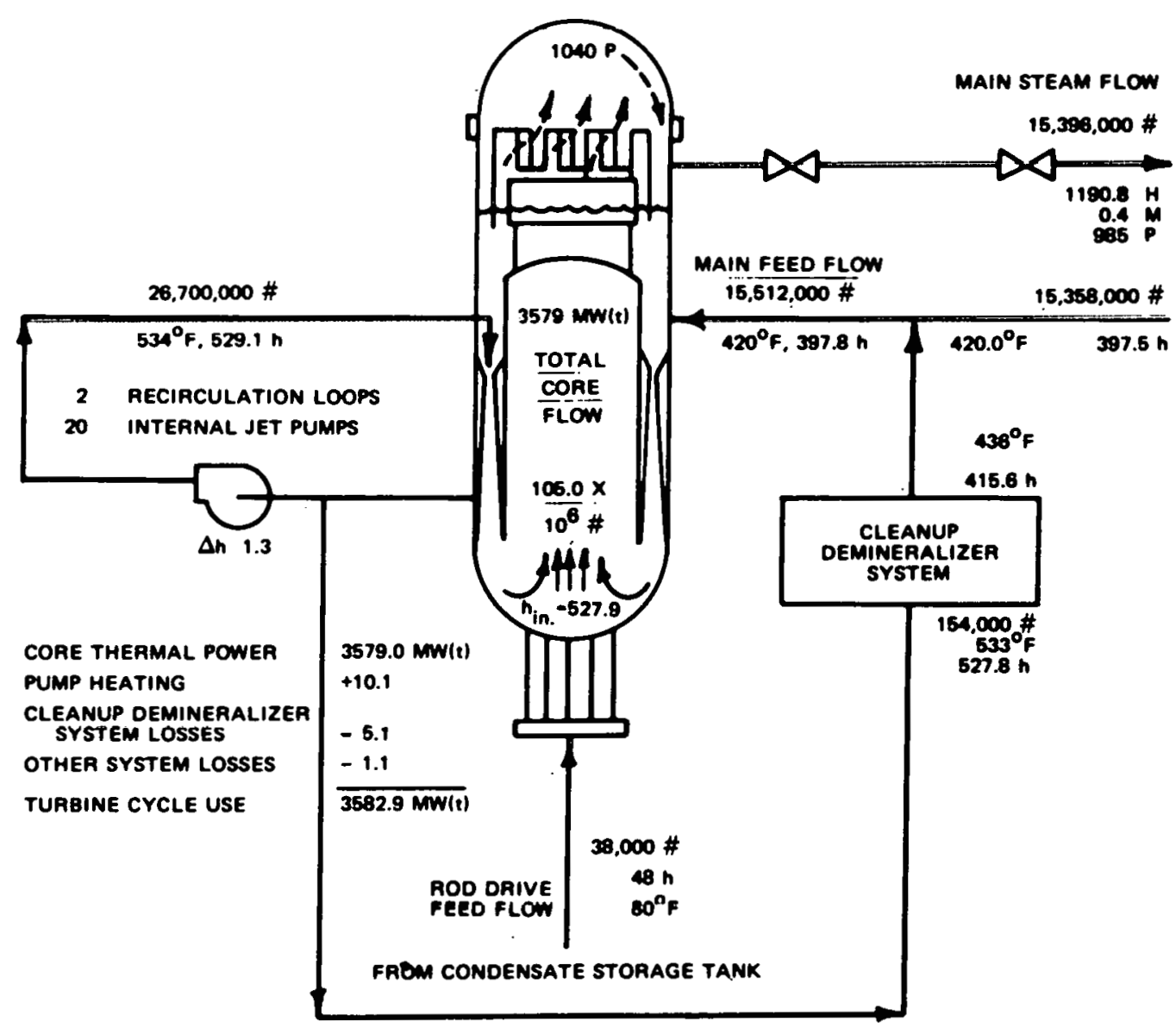

Fig. 4. Heat balance at rated power (from General Electric Company BWR/6 Standard Safety Analysis Report). 
Table 2.5. Design characteristics [3579-MW(t) BWR]

\begin{tabular}{|c|c|}
\hline \multicolumn{2}{|l|}{ Thermal and hydraulic design } \\
\hline Rated power, MW(t) & 3579 \\
\hline Steam flow rate, $\mathrm{kg} / \mathrm{s}\left(10^{6} \mathrm{lb} / \mathrm{h}\right)$ & $1890(15)$ \\
\hline Core coolant flow rate, $\mathrm{kg} / \mathrm{s}\left(10^{6} \mathrm{lb} / \mathrm{h}\right)$ & $13,230(105)$ \\
\hline Feed water flow rate. $\mathrm{kg} / \mathrm{s}\left(10^{6} \mathrm{lb} / \mathrm{h}\right)$ & $1890(15)$ \\
\hline System pressure, nominal in steam dome, MPa (abs) psia & $7.17(1,040)$ \\
\hline Temperature, ${ }^{\circ} \mathrm{C}\left({ }^{\circ} \mathrm{F}\right)$ & $216(420)$ \\
\hline \multicolumn{2}{|l|}{ Reactor vessel design } \\
\hline Material & Low-alloy steel/partially clac \\
\hline Design pressure, MPa (psig) & $8.62(1,250)$ \\
\hline Design temperature, ${ }^{\circ} \mathrm{C}\left({ }^{\circ} \mathrm{F}\right)$ & $302(575)$ \\
\hline Inside diameter, $\mathrm{m}$ ( $\mathrm{ft}-\mathrm{in})$. & $6.045(19-10)$ \\
\hline Inside height, $m$ (ft-in.) & $21.59(70-10)$ \\
\hline
\end{tabular}

Fuel for the reactor core consists of slightly enriched uranium dioxide pellets sealed in Zircaloy tuhes. These tubes (or fuel rods) are assembled into individual tuel assemblies. Gross control of the core is achieved by movable bottom-entry control rods which are cruciform in shape and are dispersed throughout the lattice of fuel assemblies. I he control rods are positioned by individual cuntiul iud drives.

Each fuel assembly has several fuel rods with gadolinia $\left(\mathrm{Gd}_{2} \mathrm{O}_{3}\right)$ mixed in solid solution with the $\mathrm{UO}_{2}$. The $\mathrm{Gd}_{2} \mathrm{O}_{3}$ is a burnable poison which diminishes the reactivity of the fresh fuel. It is depleted as the fuel reaches the end of its first cycle. The reactor vessel contains the core and supporting structures; the stea $\mathrm{m}$ separators and dryers; the jet pumps; the control rod guide tubes; the distribution lines for the feedwater, core sprays, and liquid control; the in-core instrumentation; and other components.

The main connections to the vessel include stea m lines, coolant recirculation lines, feed water lines, control rod drive and in-core nuclear instrument housings, high- and low-pressure core spray lines, residual heat removal lines, standby liquid control line, core differential pressure line, jet pump pressure sensing lines, water level instrumentation, and control rod drive system return lines.

The reactor vessel is designed and fabricated in accordance with applicable codes for a pressure of $8.62 \mathrm{M} \mathrm{Pa}(1250 \mathrm{psig})$. The nominal operating pressure in the steam space above the separators is 7.17 $\mathrm{MPa}$ (abs), (1040 psia). The vessel is fabricated of low-alloy steel and is clad internally with stainless steel (except for the top head, nozzles, and nozzle weld zones, which are unclad).

The reactor core is cooled by demineralized water that enters the lower portion of the core and boils as it flows upward around the fuel rods. The steam leaving the core is dried by steam separators and dryers located in the upper portion of the reactor vessel. The steam is then directed to the turbine through the main steam lines. Each steam line is provided with two isolation valves in series, one on each side of the containment barrier.

The reactor recirculation system pumps reactor coolant through the core. This is accomplished by two recirculation loops external to the reactor vessel but inside the containment. Each external loop contains four motor-operated valves and one hydraulically operated valve. Two of the motor-operated valves are used as pump suction and pump discharge shut off valves. The third motor-operated valve is a small shutoff valve used to bypass the large discharge valve to warm the pipeline during hot standby. The fourth motor-operated valve is in a bypass line that bypasses both the flow control valve and the discharge shutoff valve; this valve is manually set in a fixed position to adjust the bypass flow. The variable-position flow control valve in the main recirculation pipe allows control of reactor power level through the effects of coolant flow rate on moderator void content. 
The internal portion of the loop consists of jet pumps which contain no moving parts. These pumps provide a continuous internal circulation path for the major portion of the core coolant flow and are located in the annular region between the core shroud and the vessel inner wall. A recirculation line break will still allow core flooding to approximately two-thirds of the core height-the level of the inlet of the jet pumps.

Load following is normally accomplished by varying the recirculation flow to the reactor. This method of power level control takes advantage of the reactor negative void coefficient. To increase react or power, it is necessary only to increase the recirculation flow rate, which sweeps some of the voids from the moderator and causes an increase in core reactivity. As the reactor power increases, more steam is formed, and the reactor stabilizes at a new power level with the transient excess reactivity balanced by the new void formation. No control rods are moved to accomplish this power level change. Conversely, when a power reduction is required, it is necessary to reduce the recirculation flow rate. When this is done, more voids are formed in the moderator, and the reactor power level stabilizes commensurate with the new recirculation flow rate. No control rods are moved to accomplish the power reduction.

A power range of control of approximately $35 \%$ can be achieved through the recirculation flow control system. For power ranges beyond this level of control, the control rods are moved. Ramp load changes up to $0.5 \% / \mathrm{s}(30 \% / \mathrm{min})$ are available through use of the recirculation flow control.

Correct distribution of core coolant flow among the fuel asscmblies is accomplished by the use of an accurately calibrated fixed orifice at the inlet of each fuel assembly. Each orifice is located in the fuel support piece. They serve to control the flow distribution and hence the coolant conditions within prescribed bounds throughout the design range of core operation.

The core is divided into two orificed flow zones. The outer zone is a narrow, reduced power region around the periphery of the core, and the inner zone consists of the core center region.

Refueling is accomplished by removing the pressure vessel head and flooding the volume above the pressure vessel, thus providing for underwater handling of fuel and other reactor internals. Underwater storage of the irradiated fuel and reactor internal parts is accommodated by special pool storage facilities.

The fuel loading is based on a 4-year cycle. Approximately one-fourth of the core is replaced each year. The minimum downtime required for depressurization, cooldown, refueling, repressurization, and reactor startup is estimated to be 8 to 10 days.

Auxiliary systems are provided to perform the following functions:

1. purify reactor coolant water;

2. cool system components;

3. remove residual heat when the reactor is shut down;

4. cool the spent-fuel storage pool;

5. sample reactor coolant water;

6. provide for emergency core cooling;

7. collect reactor containment drains;

8. provide containment spray;

9. provide containment ventilation and cooling;

10. process liquid, gaseous, and solid wastes;

11. provide seal waler for pipes penetrating containment following a loss-of-coolant accident (LOCA);

12. provide redundant means of removing hydrogen from the containment following an LOCA;

13. provide primary coolant leak-detection system;

14. inject borated water by a standby emergency liquid control system. 


\subsubsection{Balance of plant}

The turbinc-generator system design is subject to some variation. A typical 1000-MW(e) plant would have a tandem-compound 30- $\gamma$ ps (1800-rpm) turbine with one high-pressure and three lowpressure sections. Six combination moisture separator-reheater units are used to dry and superheat the steam between the high-and low-pressure sections. A typical heat balance diagram for a 1000-MW(e) plant is shown in Fig. 5.

The containment structure completely encloses the entire reactor and reactor coolant system and ensures that essentially no uncontrolled leakage of radioactive materials to the environs would result even on gross failure of the reactor coolant system. The structure provides biological shielding for normal and accident situations and is designed to maintain its integrity under tornado wind loading, impact from tornado-generated missiles, storm winds, floods, earthquakes, tsunamis, and other natural forcess at their worst foreseeable intensity within conservatively established recurrence intervals.

General Electric Company is currently marketing a containment and uuclear design designated the Mark III, which is a complex of thrce buildings-the reactor building, the auxiliary building, and the refueling building. The Mark $11 \mathrm{I}$ containment, shown in Fig. 6, uses pressure suppression with the dry containment layoul. The dry well, which surrounds the reactor and primary cuulant system, is a pressure boundary that channels steam from the blowdown following a postulated LOCA through the suppression pool. This pool is located in the bottom of a dry containment. $\Lambda$ wcir wall and three rows of horizontal vents are used to distribute steam flowing into the suppression pool. The entire volume of the containment is open to the suppression pool. The Mark IIl concept features an upper pool which provides shielding during normal operation and refueling and is used with the suppression pool for dry-well flooding following an LOCA.

The containment structure is similar to that of a standard dry containment and can be designed either as a free-standing steel containment surrounded by a concrete shield building or as a concrete pressure vessel with a liner. The dry well is not lined, since it is a pressure barrier used to channel steam from an LOCA through the suppression pool, and is not a primary leakage barrier. Auxiliary buildings are provided to house the spent-fuel storage and handling facility, the corc standby cuuling system, and otlies reactor auxlliary equipment.

The turbine-generator building requires radiation shielding because of the direct cycle of the BWR. Steam generated in the reactor core conveys some fission products to the turbine. Fission product gases, ${ }^{16} \mathrm{~N}$, and some radioisotopes enter the turbine and turbine condenser. Approximately $80 \%$ of the activity is discharged via the air cjector on the main condenser to a system utilizing catalytic recombination and low-temperature charrnal adsorption. The catalytic recombirter recombines radiolytically dissociated hydrogen and oxygen, and charcoal adsorption beds selectively adsorb and delay zenon and krypton lrom the bulk of the carricr gas, which is principally air. After the delay, the gas is passed through a filter and discharged to the atmosphere. The other $20 \%$ of the activity follows the condensate and is treated by the condensate filter demineralizers.

Radiation shielding is provided around the following areas:

1. main steam lines,

2. primary and extraction steam piping,

3. high- and low-pressure turbines,

4. feedwateı pumps and turbines,

5. moisture separators,

6. reactor feedwater system heaters, 


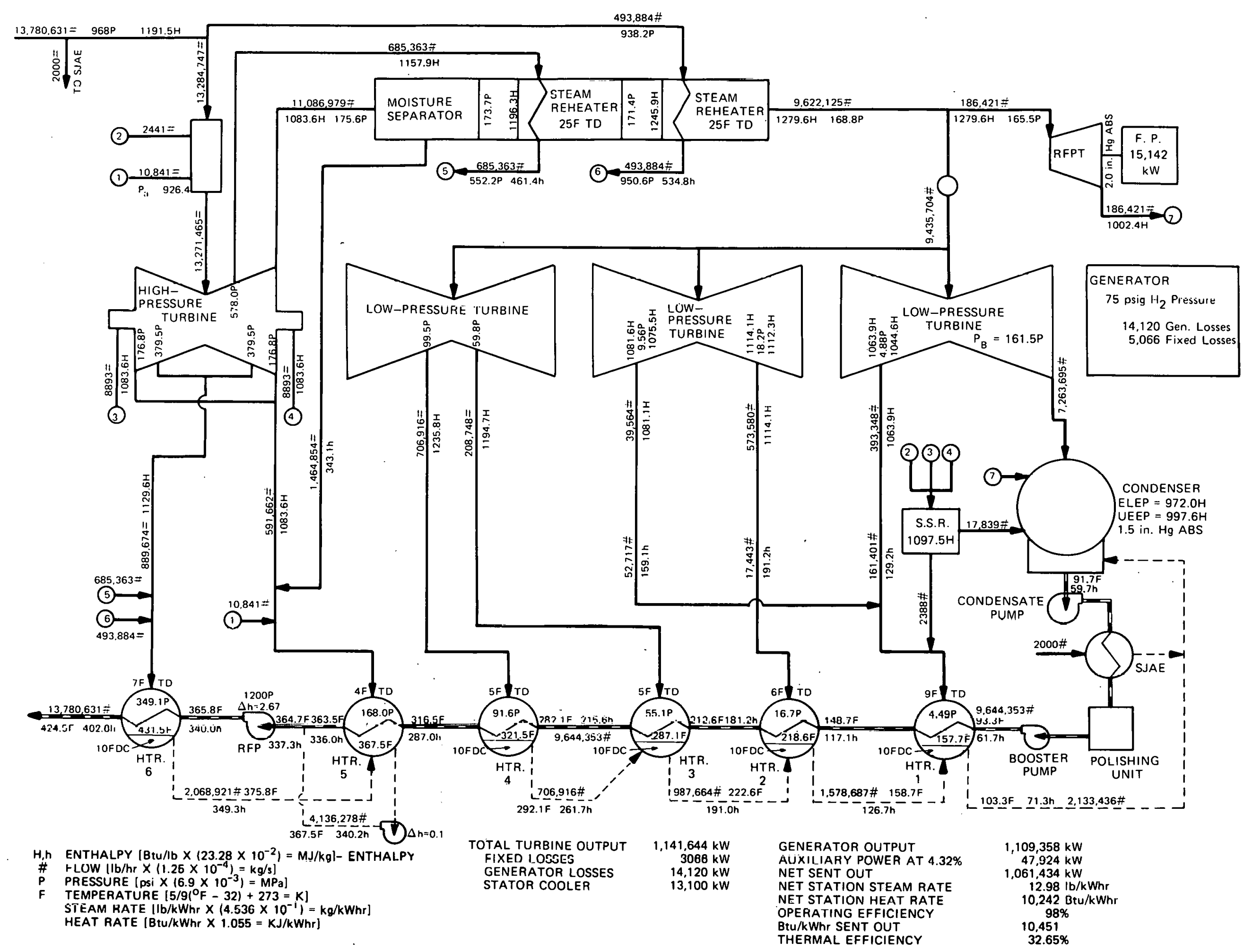

Fig 5. Typical 1000-MW(e) BWR turbine cycle heat balance diagram (from WASH-1230, Vol. II). 
ORNL-DWG 74-5671

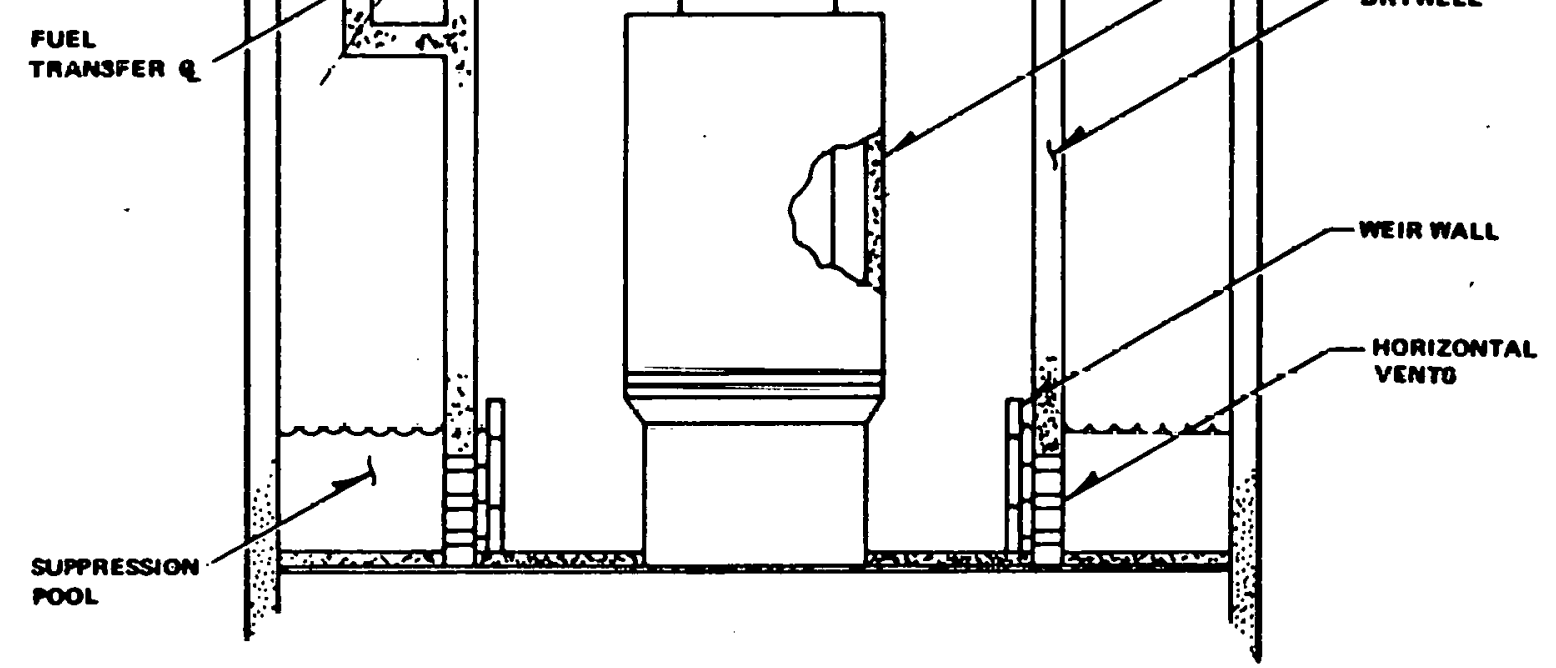

Fig. 6. Typical Mark III BWR containment (from Gencral Elcetric Company Report NEDO-10571).

7. main condenser and hot well,

8. air ejectors and steam packing exhauster.

9. condensate demineralizer,

10. off-gas lines.

Some of the equipment, such as the air ejectors, feed water pumps, and heaters, are in individual rooms, thus allowing part of the system to be shut down without interrupting plant operation. 
The control room building houses the instrumentation and controls for reactor and turbinegenerator controls. It is designed according to seismic, tornado, and flooding criteria and contains all the necessary instrumentation and control for plant operation under normal and accident conditions.

The diesel-generator building is designed to withstand short-term tornado loading, including tornado-generatcd missiles. This building houses the diesel generators that provide stand by power.

Miscellaneous structures are required for maintenance shops, chemicals storage, water-intake equipment housing, etc. Other balance-of-plant equipment and systems are similar to those required for a conventional fossil-fired plant. Included are condensers, feed water pumps, makeup water treatment systems, circulating water systems, electric plant equipment, etc.

\subsection{PWR Power Plant}

\subsubsection{Nuclear steam system}

A PWR nuclear steam system is made up of closed loops in which heat is transported from the reactor core to the steam generators by circulating pressurized water. The system consists of a reactor pressure vessel containing the reactor core, the steam generator, pumps for circulating the pressurized water, and a pressurizer that maintains and controls system pressure. A typical PWR coolant system schematic flow diagram is shown in Fig. 7. Characteristics typical of a PWR nuclear steam system (Babcock and Wilcox plant) are given in Table 2.6.

Fuel for the PWR core is contained in sealed tubes (fuel rods) which are mounted vertically. The fuel is cylindrical pellets of sintered, low-enriched uranium dioxide. The pellets are clad in Zircaloy tubing and sealed by welded Zircaloy end caps. The basic fuel assembly is composed of fuel rods, control rod guide tubes, one instrumentation tube assembly, segmented spacer sleeves, spacer grids, and end fittings. The guide tubes, spacer grids, and end fittings form a structural cage to arrange the rods and tubes in an array.

Core reactivity is controlled by control rod assemblies and soluble boron dissolved in the primary reactor coolant. The control rods, which move vertically, arc actuated by electrically-driven control rod drive mechanisms mounted on top of the reactor pressure vessel.

The reactor vessel contains the core and supporting structures, thermal shield, in-core instrumentation, and other components. The main connections to the reactor vessel are the main coolant lines on the side, control rod drive mechanisms on the top, and instrument lines nn the bottom. The vesscl is tabricated of low-alloy steel and is clad internally with stainless steel.

The reactor core is cooled by demineralized water that enters the side of the vessel, flows downward to the lower end of the vessel, upward through the core, around the fuel rods, and out the pipe connections on the side of the vessel. The coolant is piped to the steam generator, to the main circulating pumps, and back to the reactor vessel in a closed loop. It is necessary to maintain the primary coolant system pressure high enough to prevent boiling. This is done by an electrically heated pressurizer tied into the system that serves to control the coolant pressure and absorb some volume variations of the primary coolant. Steam generated in the steam generators is piped to the steain turbine, passed through the turbine, condensed, and returned by a boiler feedwater system in the same manner as in a conventional fossil-fired plant.

The react or vessel, main coolant piping, stean generators, pressurizer, and coolant circulating pumps are all located inside the containment structure. Steam lines penetrate the containment and convey the steam to the turbine building, which is not a containment structure. 


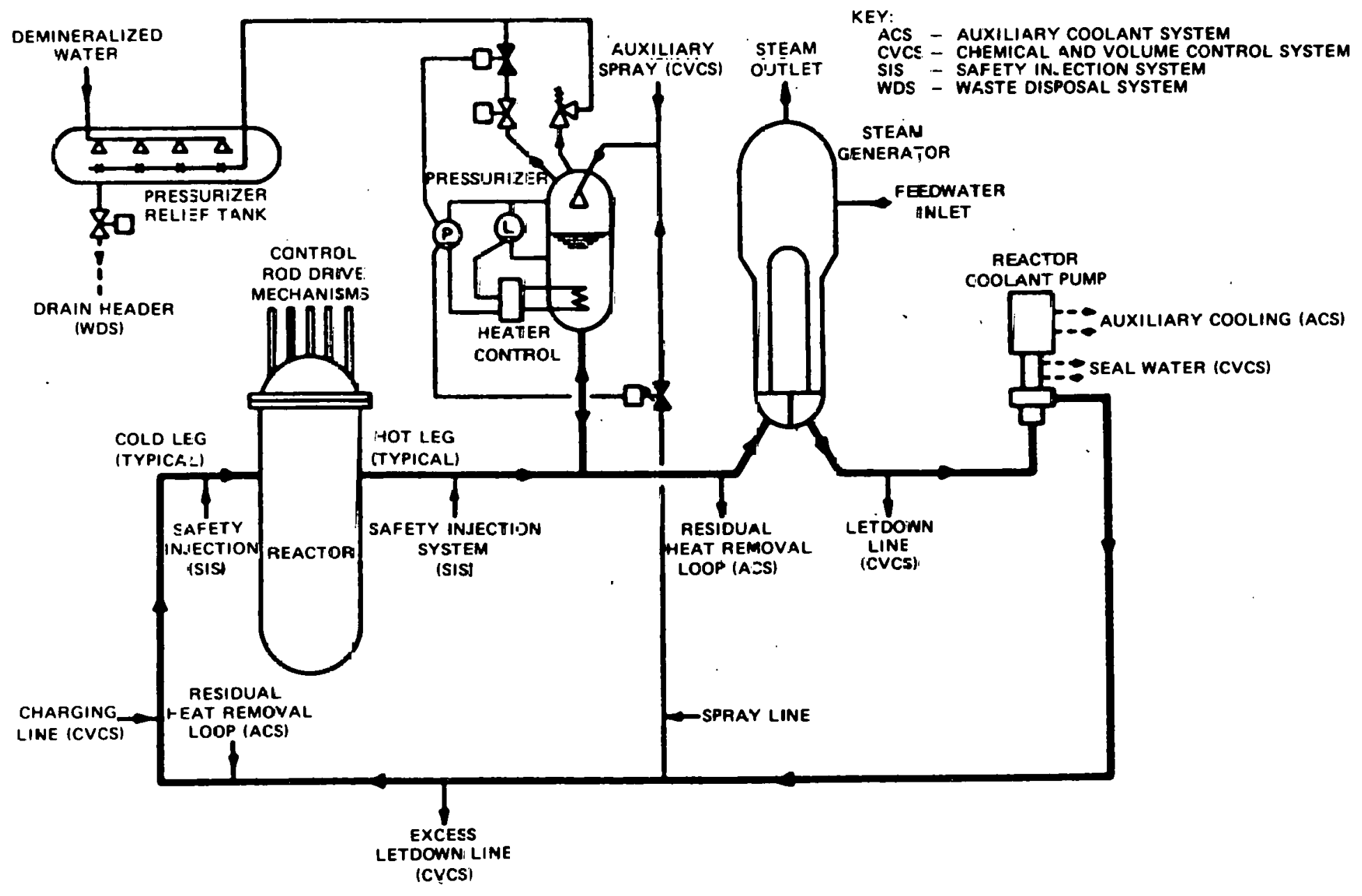

Fig. 7. Typical PWR :eactor coclant system (from Westingtouse Ele:tric Corporation). 
Table 2.6. Design characteristics [3411-MW(t) PWR]

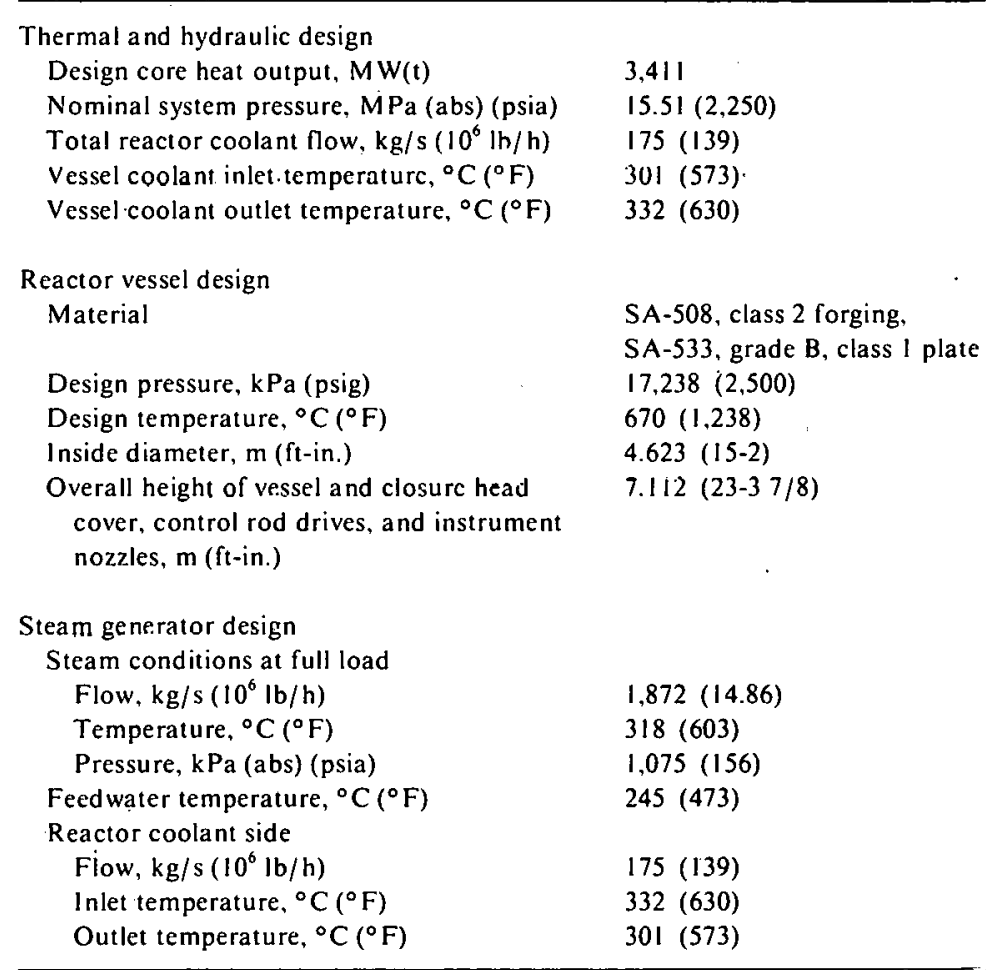

Refueling of the reactor is accomplished by removing the pressure vessel head and flooding the volume above the vessel. Underwater handling of fuel and other reactor components is then possible. Underwater storage of the irradiated fuel and reactor internals is accommodated by pool storage facilities.

The fuel loading of the large PWR core is generally based on a 3-ycar cycle. Approximately one-third of the core is replaced annually. The minimum downtime required for depressurization, cooldown, refueling, repressurization and startup is about 10 days.

Auxiliary systems are provided to perform the following functions:

1. charge the reactor coolant system;

2. add makcup wateı;

3. purify reactor coolant water;

4. provide chemicals for corrosion inhibition and reactor control;

5. cool system components;

6. remove residual heat when the reactor is shut down;

7. cool the spent-fuel storage;

8. sample rcactur coolant wäter;

9. provide for emergency core cooling;

10. collect reactor coolant drains;

11. provide containment spray;

12. provide containment ventilation and cooling;

13. dispose of liquid, gaseous, and solid wastes;

14. provide seal water for pipes penetrating containment following an LOCA; 
15. provide cooling for containment penetrations with hot pipes;

16. provide redundant means of removing hydrogen from containment following an LOCA;

17. provide main coolant leak-detection system.

\subsubsection{Balance of plant}

The turbine-generator system design is subject to some variation. A typical 1000-MW(e) plant would have a tandem-compound 60- $\gamma$ ps (1800-rpm) turbine with one high-pressure and three lowpressure sections. Six combination moisture separator-reheater units are employed to dry and superheat steam between the high- and low-pressure turbine sections. A typical heat balance for a 1000-MW(e) plant is shown in Fig. 8.

The containment structure completely encloses the entire reactor and reactor coolant system to ensure that essentially no leakage of radioactive malerials to the envirnnment would result even on gross failure of the reactor coolant system. The structure provides biological shielding for normal accident conditions and is designcd to maintain its integrity under tornado wind loading, impact from tornado-generated missiles, storm winds, floods, earthquakes, tsunamis, and other natural forces at their worst foreseeable intensity within cunscrvatively estahlished recurrence intervals. The containment building is a concrete structure with a steel liner to ensure leak tightness. A typical 1000MW(e) plant has a concrete contaimment struoture with an inside diameter of approximately $41.1 \mathrm{~m}$ $(135 \mathrm{ft})$ and an overall inside height of approximately $20.4 \mathrm{~m} \mathrm{(67ft).} \mathrm{A} \mathrm{typical} \mathrm{PWR} \mathrm{containment}$ building and nuclear steam system are shown in Fig. 9.

\subsection{Environmental Parameters}

The construction of a power plant, nuclear or fossil fueled, will inevitably affect the environment, and some of the effects will be adverse. Effects ate considcred adverse if environmental change causes some bintic population or nonviable resource to be less safe, less abundant, or less aesthetically pleasing; if the change reduces the diver sity and variety of individual choice or the standard of living; or if the change tends to lower the quality of renewable resources or to impair the recycling of depletable resources. The severity of adverse effects should be reduced to minimum practicable levels.

Prior to the issuance of a construction permit or operating license for a nuclear power plant, the utility must submit a report on the potential enviromental impacts of the proposed plant and associated facilities.' Some of the environmental para meters considered in an environmental report are as follows:

1. the site,

2. the plant,

3. effects of site preparation and plant and transmission facilities construction,

4. effects of plant operation,

5. effluent measurement and monituring,

6. effects of accidents,

7. economic and social effects of plant construction and operation,

8. alternative energy sources and sites.

In this study, attention is confined to the environmental effects of plant operation. The two principal impacts are due to waste heat and radioactivity, although chemical effluents and others are important. 


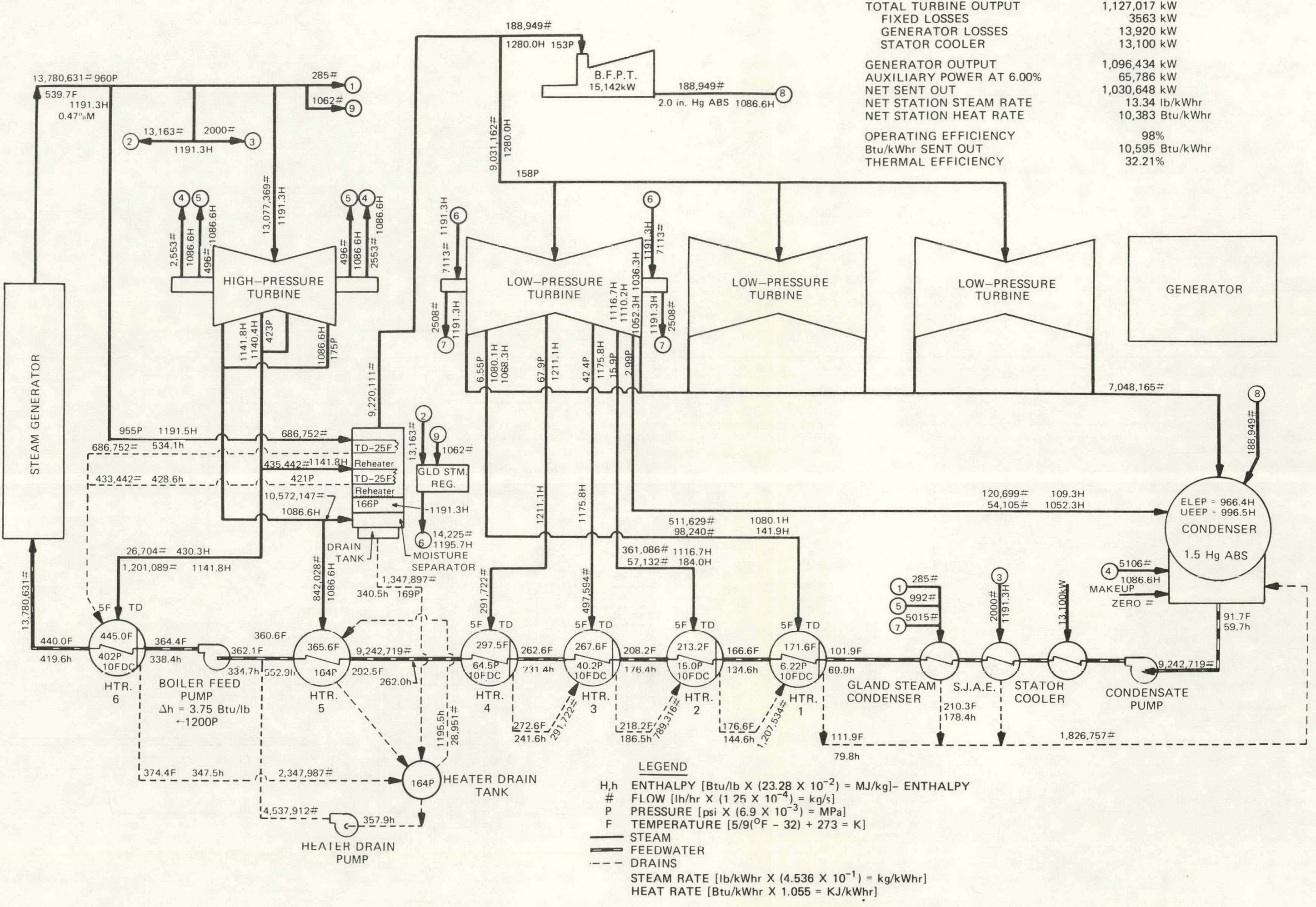

Fig. 8. Typical 1000-MW(e) PWR turbine cycle heat balance diagram (from WASH-1230, Vol. 1). 


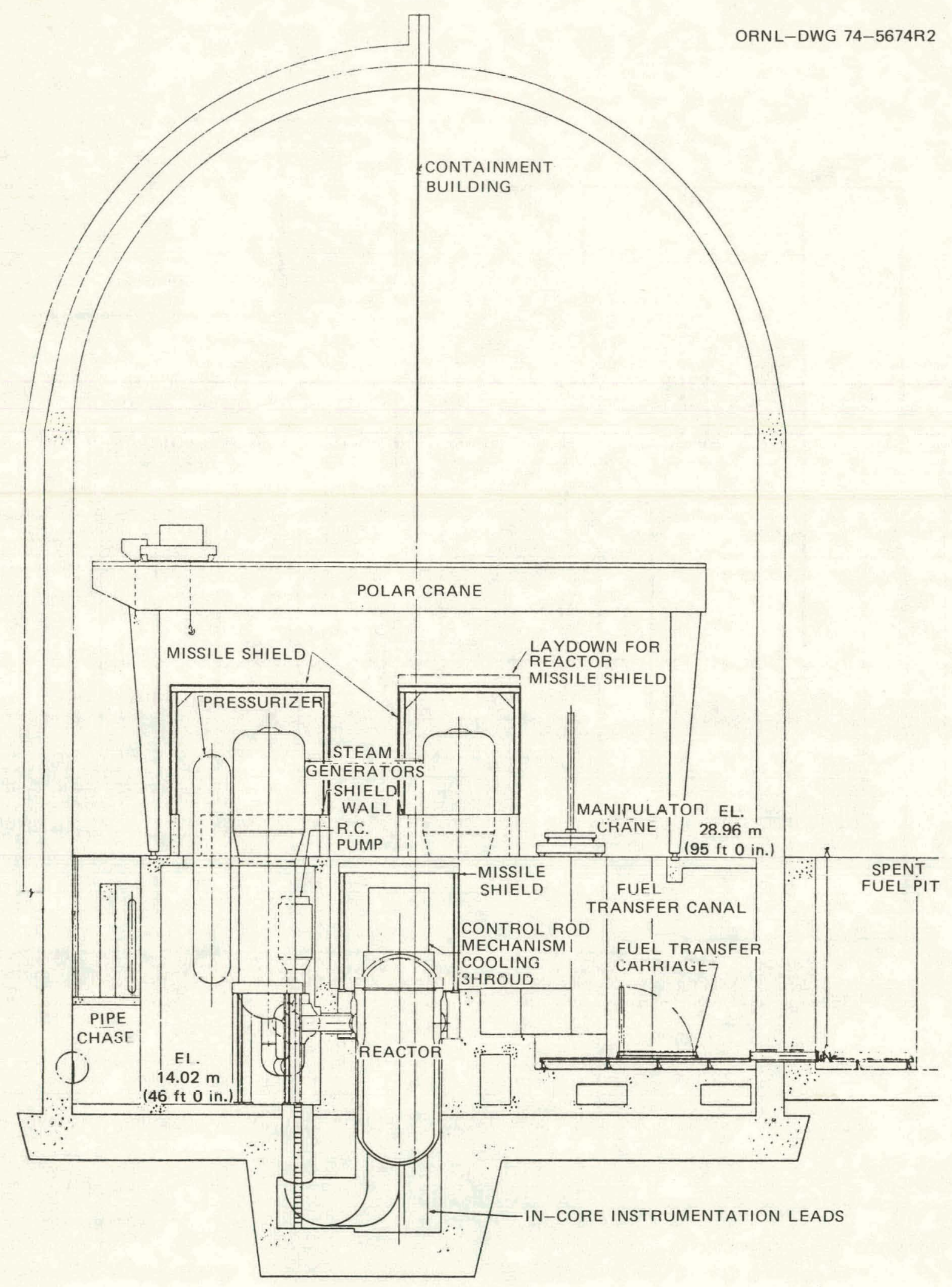

Fig. 9. Typical PWR containment (from WASH-1082). 


\subsubsection{Waste heat}

Regardless of the thermal source in a power plant, about 60 to $70 \%$ of the heat produced is rejected to the environment. Figure 10 shows heat balances for two types of plants, each producing $1000 \mathrm{MW}(\mathrm{e})$. The LW R plant is assumed to have an efficiency of $33 \%$, while fossil-fuel plants have efficiencies of $38 \%$. It is assumed that $85 \%$ of the waste heat is carried off by the condenser cooling water for the fossil-fuel plant and $95 \%$ for the nuclear-fuel plant. The LWR plant deposits about $50 \%$ more waste heat in the condenser water than the fossil-fuel plant.

The two major types of cooling systems in use are the open cycle and the closed cycle. The open cycle is generally referred to as the "once-through" system, since the cooling water from the river, lake, ocean, or other source is pumped through the condenser and then returned to the source. In the closed cycle, water is recirculated through the condenser after it has been cooled in a cooling tower or pond. Cooling towers may be either wet or dry, natural draft or mechanical draft. Cooling ponds may use large acreage [about $4.05 \mathrm{~m}^{2}$ to $8.10 \mathrm{~m}^{2} \times 10^{3}$ (1 to 2 acres) per megawatt of installed capacity] or sprays to ensure the desired degree of cooling.

Cooling ponds and wet towers may cause objectionable fogs, icing, or plumes. In addition, the size of the pond or tower may be objectionable.

The plume of the wet tower can be reduced or eliminat ed by using wet/dry towers. ${ }^{2}$ In these towers, only part of the heat is removed with water; enough heat is removed with the air-water vapor mixture so that the relative humidity is much reduced. Such towers also reduce water consumption.

\subsubsection{Radiological}

During the operation of a nuclear power plant, radioactive gases are produced by activation of such materials as argon, nitrogen, and oxygen; iodine, krypton, and xenon are produced in the fuel by fission. The amount of the latter three in the reactor coolant depends on the integrity of the fuel elements. With the passage of time, the fuel cladding develops pinhole leaks, and the fission product gas escapes into the coolant.

The plants are designed ${ }^{3}$ to operate with fuel element leakage up to about $1 \%$. In the BWR, the gases released to the primary coolant are carried to the turbine and to the condenser along with the steam. Steam is condensed back to water, but the noncondensable gases, including the very small volume of radioactive gases, are vented to a cleanup system. After some time for decay, the gases are filtered and relcased to the environment through the stack. In the. PWR, most of the radioactive gases remain in the coolant water. When the system is opened for maintenance or refueling, the gases are vented to a cleanup system from which they may be released to the at mosphere.

Also radioactive materials build up in the cooling water during reactor operation. Some of these result from activation of elements in the water itself - the naturally occurring trace elements.

Others are generated by neutrons absorbed by the metals, mainly stainless steel or Zircaloy in the reactor system. Other radioactive products leak out of the fuel elements. In addition, tritium is produced in the coolant and fuel elements.

Liquids leaking into and recovered from various plant systems are collected and sent through a special liquid-waste system where the radioactivity is concentrated and put in a form suitable for shipping to disposal grounds. The effluent liquids left over are collected in monitoring tanks, checked for radioactivity, and released at a controlled rate in the plant condenser cooling water.

Solid wastes are generally disposed of off site. 

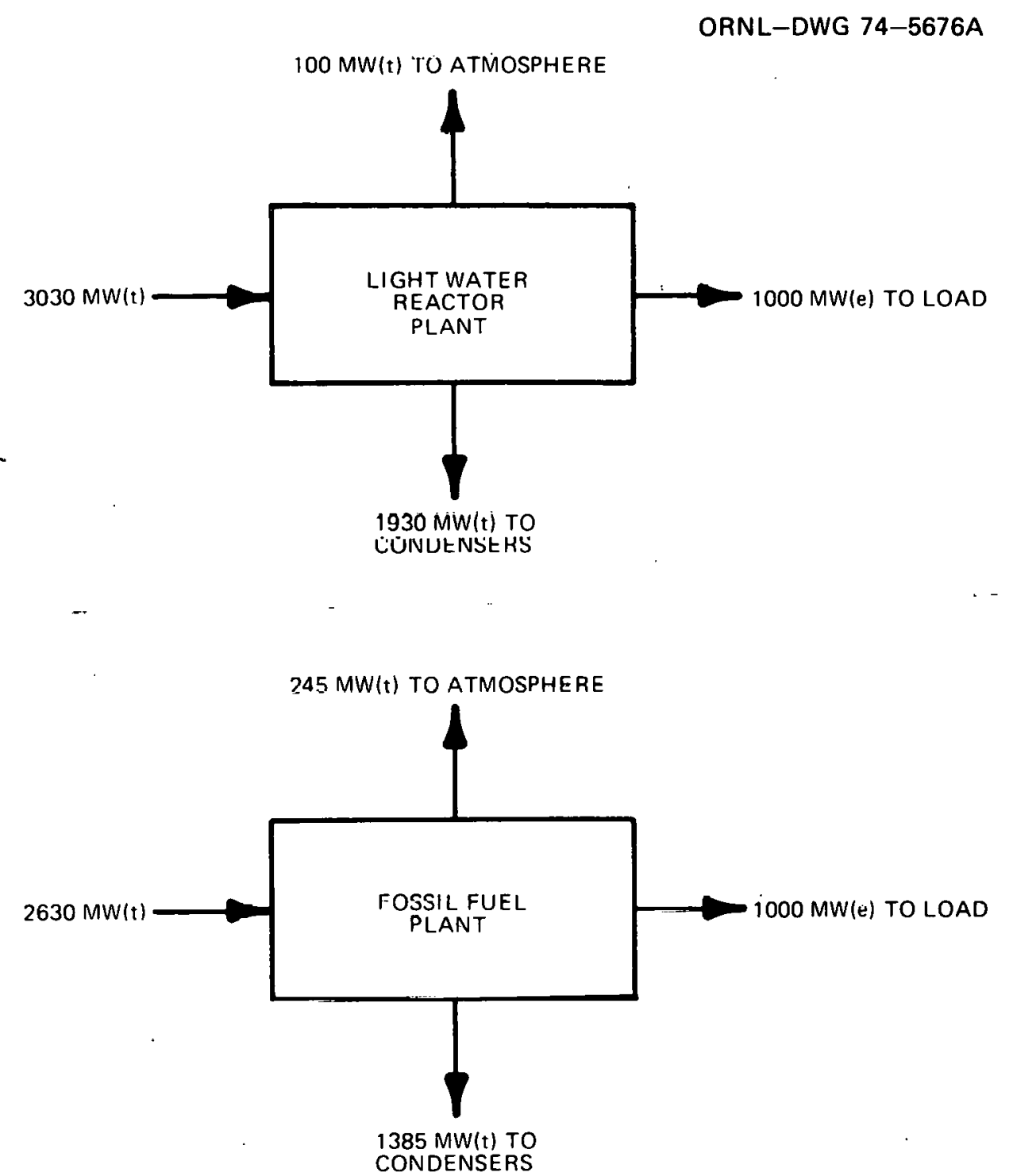

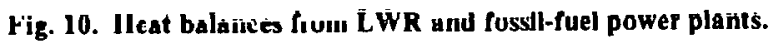

\subsection{Operating and Maintenance Manpower Needs}

The staffing of a commercial nuclear power plant with operating and maintenance personnel requires careful selection and training of personnel as well as careful timing in the hiring of the staff. The complexity and newness of the work, the problems caused by radiation, and the high cost of outage justify more than ordinary planning in the hiring and training of a staff.

The staff of a large utility may be divided into two large groups: the home office (or headquarters staff) and the operating staff. It is assumed that the headquarters staff is already functioning, and the emphasis is on the operating and maintenance staff. The following general discussion can be applied to all types of reactors. 


\subsubsection{Operations and maintenance staff}

Although plant staff organizations can reflect variations in company policies and practices, the representative organization shown in Fig. 11 can be satisfactorily employed to operate a currentgeneration single-unit station. ${ }^{4}$

ORNL - DWG 75-13164R

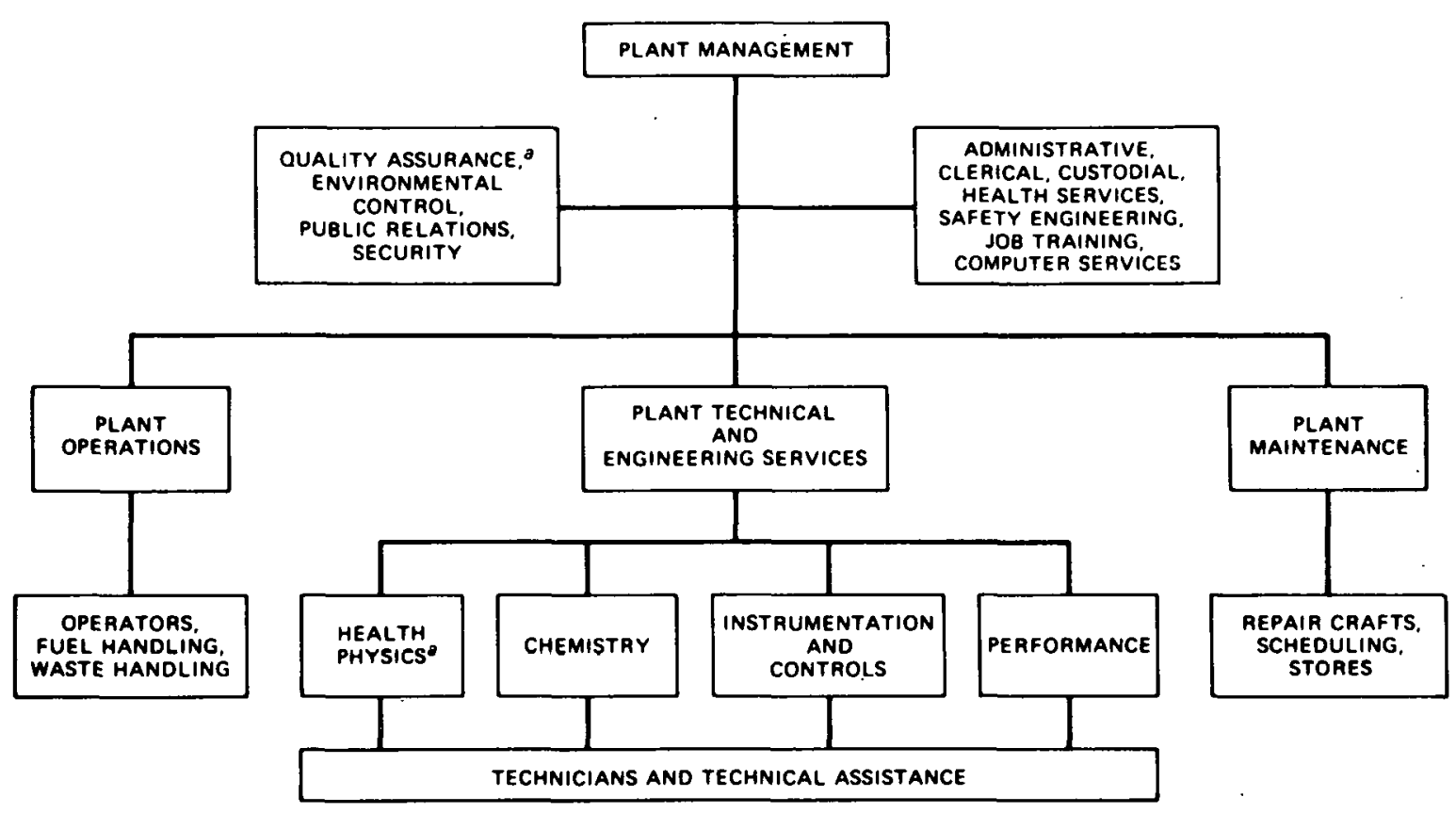

a Not Required for Fossil-Fueled Plants

Fig. 11. Typical functional organization chart for steam-electric power plant staff.

Each nperating shift crew consists of a senior licensed shift supervisor, two licensed control operators, and two auxiliary operators. Five such crews should be trained to handle all normal and abnormal operating procedures. At least one replacement for each of the three categories should be trained and available to maintain crew strength when job shifts, resignations, or retirements occur and to accommodate on-site fuel handling procedures.

Direct day-to-day technical support for plant operations is a necessity. The vital technical areas are radiation protertion, plant chemistry, instrumentation and controls, reactor, turbine generator, and balance-of-plant equipment. Functions include routine monitoring, surveys, sampling, analyses, instrument checking and maintenance, performance analysis, test preparations, and evaluation of results.

Electrical and mechanical maintenance requirements noted are largely aimed toward the preventive maintenance program but will allow for some repair and corrective maintenance. Certain specialized craft skills not routinely needed at the plant site may come from a more centralized systcmwide maintenance staff or from outside organizations. 
A plant security force of 56 provides for supervisor and shift crews for round-the-clock coverage except for four unit stations which require up to twice that number. Due to the specialized training required for security force personnel, they may be administratively attached to a separate organization reporting to headquarters.

The timing of the selection and appointment of personnel to a plant staff is an important consideration to assure that full qualifications requirements are met by the staff when the plant is ready. Management and key supervisory personnel should be on board not later than 4 years before initial fuel loading. Operating crew personnel should be selected at least 3 years in advance of fuel loading so that they will have completed virtually all formal and experience training requirements by the time the preoperational test program begins. Technical support personnel should be selected and assigned within the 2- or 3-year period ahead of fuel loading for training and familiarization assignments. Security personnel may be required to protect property early in the construction period but should be fully trained and on the job during preoperational testing.

The staffing of multiple-unit stations must provide for the performance of essentially the same functions as are required for single units. There are considerations, however, which may make it unnecessary to duplicate single-unit staff entirely. Some of these are (1) the degree of similarity in design features and operating characteristics and the reflection of these in operability and maintainability, (2) the extent to which some systems (e.g., waste management) are common, and (3) the absence of overlapping startup and break-in periods for successive units during which manpower demands may be heavier'.

Table 2.7 displays the organizational breakdown for representative multiple-unit stations. Study of the comparison shown with a single-unit station staff structure demonstrates the potential applicability of the above factors, viz., identical units with a common control room and some shared systems.

It will be noted that it also reflects an opportunity for more effective use of manpower through specialization of the operational fuel management function on site. A fuel handling team should be considered in lieu of additional "regular" operating personnel for multiple-unit stations. The team's responsibilities would cover all phases of fuel handling on site, from receipt, inspection. storage, inventory control, refueling and unloading the core, spent fuel handling, rask lnading, and shipment of spent fuel. The lead fuel handlers (or foremen) of this team wnuld be expected to qualify for senior operator licenses which can be restricted to cover the scope of their activities.

Staffing for the desalting plant is discussed in Sect. 4.2.

\subsubsection{Staff training}

Concurrently with the obtaining of a staff so that the plant may be put in operation upon completion, a training program must be in operation. Various standards have been prepared describing the qualitication requirements for a variety of positions. The American Nuclear Society standard, Selection and Training of Nuclear Power Plant Personnel, specifies minimum general qualifications and specific education, training, and experience for all functional levels within an operating organization that have a direct relationship to technical operational and maintenance aspects of a nuclcar plant.

Figure 12 is a schedule for training senior operators and operators at the appropriate time. Other plant staff members new to the nuclear industry can benefit by participation in these programs even though they will not need licenses. 
Table 2.7. Staffing requirements for multiple-unit nuclear steam-electric power plants

\begin{tabular}{|c|c|c|c|c|c|c|c|c|}
\hline \multirow{3}{*}{. } & \multicolumn{4}{|c|}{$400-700 \mathrm{MW}(\mathrm{e})$ unit } & \multicolumn{4}{|c|}{$701-1300 \mathrm{MW}(\mathrm{e})$ unit } \\
\hline & \multicolumn{4}{|c|}{ Units per site } & \multicolumn{4}{|c|}{ Units per site } \\
\hline & 1 & 2. & 3 & 4 & 1 & 2 & 3 & 4 \\
\hline \multicolumn{9}{|l|}{ Plant Manager's office } \\
\hline Manager & 1 & 1 & 1 & 1 & 1 & 1 & 1 & I \\
\hline Assistant & 1 & 2 & 3 & 4 & 1 & 2 & 3 & 4 \\
\hline Quality assurance & 3 & 1 & 5 & 6 & 3 & 4 & 5 & 6 \\
\hline Environmental control & 1 & 1 & 1 & 1 & 1 & 1 & 1 & 1 \\
\hline Public relations & 1 & 1 & 1 & 1 & 1 & 1 & 1 & 1 \\
\hline Training & 1 & 1 & 2 & 2 & 1 & 1 & 2 & 2 \\
\hline Safety & 1 & 1 & 1 & 1 & 1 & 1 & 1 & 1 \\
\hline Administrative services & 13 & 15 & 17 & 19 & 13 & 15 & 17 & 19 \\
\hline Health services & 1 & 1 & 1 & 1 & 1 & 1 & 1 & 2 \\
\hline Security & 56 & 56 & 56 & 105 & 56 & 56 & 56 & 112 \\
\hline Subtotal & 79 & 83 & 88 & 142 & 79 & 83 & 88 & 149 \\
\hline \multicolumn{9}{|l|}{ Operations } \\
\hline Supervision (excluding shift) & 2 & 2 & 4 & 4 & 2 & 2 & 4 & 4 \\
\hline Sthifts & 28 & 48 & 68 & 88 & 33 & 58 & 83 & 108 \\
\hline Subtotal & 30 & 50 & 72 & 92 & 35 & 60 & 87 & 112 \\
\hline \multicolumn{9}{|l|}{ Maintenance } \\
\hline Supervision & 8 & 8 & 10 & 12 & 8 & 8 & 10 & 12 \\
\hline Crafts & 14 & 22 & 30 & 38 & 16 & 26 & 36 & 46 \\
\hline Peak maintenance annualized & 55 & 110 & 165 & 220 & 55 & 110 & 165 & 220 \\
\hline & $\overline{77}$ & $\overline{140}$ & $\overline{205}$ & $\overline{270}$ & $\overline{79}$ & $\overline{144}$ & $\overline{211}$ & \\
\hline Subtotal & 77 & 140 & 205 & 270 & 79 & 144 & 211 & 278 \\
\hline \multicolumn{9}{|l|}{ Technical and engineering } \\
\hline Reactor & 1 & 2 & 3 & 4 & 1 & 2 & 3 & 4 \\
\hline Radiochemical & 2 & 2 & 3 & 4 & 2 & 2 & 3 & 4 \\
\hline Instrumentation and controls & 2 & 2 & 3 & 4 & 2 & 2 & 3 & 4 \\
\hline Performance, reports, and technicians & 17 & 21 & 25 & 29 & 17 & 21 & 25 & 29 \\
\hline Subtotal & 22 & 27 & 34 & 41 & 22 & 27 & 34 & 41 \\
\hline Total & 208 & 300 & 399 & 545 & 215 & 314 & 420 & 580 \\
\hline Less security & 152 & 24 & 343 & 440 & 159 & 258 & 364 & 468 \\
\hline Less serurity a tud peak maintenance & 97 & 134 & 178 & 220 & 104 & 148 & 199 & 248 \\
\hline
\end{tabular}

Part of the training may be provided by reactor manufacturers, government agencies, universities, or consultants. In general, most utilitites provide their own design familiarization and on-the-job training just prior to the initial fuel loading and power escalation program.

The typical schedule given in Fig. 12 assumes the individual has no prior knowledge of reactor operations but has pertinent experience to qualify for the Nuclear Regulatory Commission (NRC) license examinations prior to initial operation of the station. They usually join the station staff group for further training and experience.

The training (for operators and staff) indicated in Fig. 12 is keyed to several different phases considered standard.

Phase 1 - Introduction to Nuclear Power. Participants receive instruction in basic nuclear physics and mathematics refresher, reactor physics concepts (flux, reactivity, cross section), and characteristics and operating behaviơr of power reactors. 


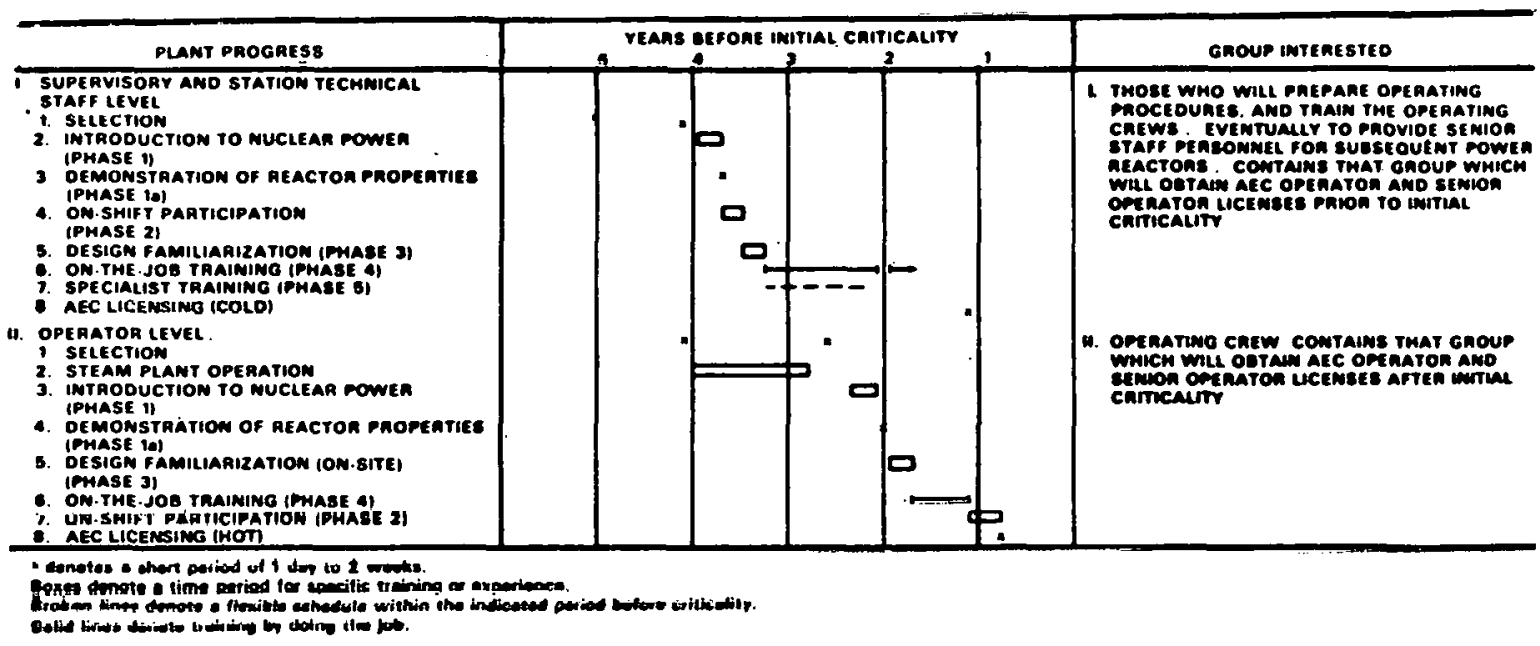

Fig. 12. Schedüle for training and experience (from WASH-1130 revised).

Phase 1a-Demonstration of Reactor Properties. A low-power research reactor is used in conjunction with or immediately following phase 1 .

Phase 2-On-Shift Participation. Extensive operative experience at a similar power reactor or a combination of experience at a power reactor and a power reactor simulator serves both to give experience and show the practical applications of theory learned.

Phase 3-Design Familiarization. Lectures, together with study of plant systems and discussion with various design groups at the nuclear steam supply system designer's location, provide familiarity with systems purpose and function.

Phase 4-On-the-J ob Training. Details of the individual plant operation are learned by assisting in the initial check-out, writing procedures, and operating the various plant systems. In addition, regularly scheduled training sessions should be directed toward design, nuclear characteristics, operating procedures, and administrative controls.

Phase 5-Specialty Training. Specific job functions (e.g., radiation monitoring or instrument maintenance) are generally taught at the appropriate time.

\subsection{Downtime for Refueling and Other Maintenance}

Most operating power reactors are refueled approximately once every year, with the first refueling within 1 or 2 years after the start of commercial operation. Refueling is not necessarily, but is invariahly, accompanied by a major maintenance outage.

A survey of the operating experience of ten reactors* for the first half of 1973 shows that the average downtime ${ }^{5}$ during refueling was about 62 days. The actual refueling time was approximately 31 days.

During refueling, there is generally a radial reshuffling of the old fuel, and about one-third of the fuel is replaced. Sometimes the utility does the refueling, and other times a vendor refueling crew under contract to the utility performs the service.

*The reactors are Big Rock Point I, Dresden 3, LaCrosse, Millstone Point I, Monticello, Nine Mill Point, Oyster Creek, Point Beach 1, Robinson 2, and San Onofre. 
The operating experience data for LWR plants that is representative of current plant designs and power levels has been summarized by Sullivan, et. al. ${ }^{6}$ The following tables (Tables $2.8,2.9$ ) taken from this report, summarize the operating and availability data for the 54 nuclear power units which were operating at that time. The maximum dependable capacity (MDC) is defined as the dependable main-unit capacity (net), winter or summer, whichever is smaller. The MDC often differs from the unit

Table 2.8. Power generation data for commercial nuclear power units (June 1976)

Licensed power reactors

$\begin{array}{ccc}\text { Number } & & \text { Capacity }^{a} \\ 54 & \text { In commercial operation } & \text { [MW(e) net] } \\ 3 & \text { In power ascension phase } & 32,660 \\ 1 & \text { Unavailable for power production } & \\ - & & 2,055 \\ 58^{c} & & 262 \\ & & 34,977\end{array}$

Power generation

\begin{tabular}{lccc}
\hline & $\begin{array}{c}\text { Report } \\
\text { month }\end{array}$ & $\begin{array}{c}\text { Previous } \\
\text { month }\end{array}$ & January-June \\
\hline Gross electrical, M Wh & $16,100,253$ & $12,359,865$ & $85,130,110$ \\
Net electrical, MWh: & $15,348,011$ & $11,704,129$ & $80,877,502$ \\
Average reactor service factor, \% & 74.0 & 59.5 & 65.2 \\
Average reactor availability factor, \% & 80.1 & 63.4 & 68.1 \\
Average unit service factor, $\%$ & 72.1 & 56.8 & 63.0 \\
Average unit availability factor, \% & 74.1 & 57.4 & 63.5 \\
Average unit capacity factor (M DC), \% & 66.3 & 54.2 & 58.1 \\
Average unit capacity factor & 59.3 & 45.9 & 52.3 \\
[design MW(e)], \%. & & & 13.4 \\
Forced outage rate, \% & 10.0 & 15.3 & \\
\hline
\end{tabular}

${ }^{a}$ Based on maximum dependable capacity; design capacity used if MDC not determined.

${ }^{b}$ Indian Point 1 shut down.

'Peach Bottom I not included; being decommissioned.

${ }^{d}$ The average reactor availability factor is of interest in the present study because it indicates the fraction of the lime lliat the reactor is available for service hours plus the reserve slıutdown hours divided by the gross hours in the period.

Table 2.9. Outage data for commercially operated nuclear power plants (June 1976) ${ }^{a}$

\begin{tabular}{lcccc}
\hline & Number & Hours & $\begin{array}{c}\text { Percent } \\
\text { clock lime }\end{array}$ & $\begin{array}{c}\text { Lost electricity } \\
\text { production (MWhr) }\end{array}$ \\
\hline $\begin{array}{l}\text { Foroed outages during } \\
\text { the month } \\
\begin{array}{l}\text { Scheduled outages } \\
\text { during the month }\end{array}\end{array}$ & 54 & $3,291.5$ & 8.8 & $1,727.807$ \\
\begin{tabular}{l} 
Tolal \\
\hline
\end{tabular} & 81 & $7,537.7$ & 19.7 & $2,931,753$ \\
\hline
\end{tabular}
period.

${ }^{\circ}$ Capacity factor of 0.75 was assumed for units that did not operate at all during the 
design electrical rating because the unit efficiency may vary during the year due to cooling water temperature variations. The net $M D C$ is the gross electrical output, as measured at the output terminals of the turbine generator during the most restrictive seasonal conditions (usually summer), less the normal station service loads. The MDC can be used to compute the unit capacity factor. The report also presents data, (Table 2.10), on availability vs unit size which indicates a higher availability for smaller units. It should also be noted that the smaller units are also those which have been operating the longest and most operating problems have been corrected.

Table 2.10. Unit size vs reactor availability factor and unit forced outage rate for plants operating in June 1976

\begin{tabular}{|c|c|c|}
\hline Unit size & $\begin{array}{c}\text { Average reactor } \\
\text { availability factor } \\
\text { (IK) }\end{array}$ & $\begin{array}{l}\text { Average unit } \\
\text { forced outage rate } \\
\text { (元) }\end{array}$ \\
\hline $\begin{array}{l}<175 \mathrm{MW}(\mathrm{e}) \\
\text { (1 plant) }\end{array}$ & 100.0 & 0.0 \\
\hline $\begin{array}{l}175 \_449 \mathrm{M} W(\odot) \\
(10 \text { plants })\end{array}$ & P6.5 & 7.5 \\
\hline $\begin{array}{l}500 \mathrm{MW}(\mathrm{c}) \text { and above } \\
(34 \text { plants })\end{array}$ & 86.9 & 7.6 \\
\hline
\end{tabular}

\subsection{Construction Schedule}

Figure 13 shows in schematic form the major elements of lead time for a multiple-unit nuclear power plant project from "commitment" to commercial operation. The time allowances are typical of the present generation of custom-designed plants but include no provision for major delays caused by strikes, contested hearings, or design revisions.

\subsection{General Factors}

\subsubsection{Plant size and number of units}

In practice the selection of unit size and the number of units is a complex decision. The site selection and load projection requirements for the area being served are outstanding considerations. The average unit size is near 1000-MW(e). This means that many units will be in the $1200-\mathrm{MW}(\mathrm{e})$ range, but still the "under 1000-MW(e)" class will have a place. Two units (or pairing) are considered the desirable grouping. This tends to penalize three-unit plants in terms of O\&M costs. However, the utility Industry trend a apjears to be toward two-unit plants and tour-unit plants built in two-unit pairs. There are notable exceptions, e.g., Browns Ferry, Uconee, Perkins, and Cherokee, which are all three-unit plants.

\subsubsection{Backfitting}

Examples of current backfitting requirements include improvements to emergency core cooling systems, control instrumentation radioactive waste systems, and condenser cooling systems. Although backfitting expenses are primarily of a capital cost nature, they often show up as charges to annual O\&M. In this report, it is assumed that the plant meets all regulatory guidelines and that it will be free 
Years to commercial speration

First unit

Second unit

Fourth uri

1. On-site construction

2. Long lead-time ecuipment

3. NRC safe:y review

4. Antitrust rejiew

5. Environmemal review in parallel with NRC slety review

6. Contractual arrangements

Legend

1. On-site construction

2. Long lead-time equipment

3. NRC safaty review

4. Antitrus: review

$\begin{array}{rr}9 & 8 \\ 10 & 9 \\ 11 & 10 \\ 12 & 11\end{array}$

7
8
9
10

$\begin{array}{ll}6 & 5 \\ 7 & 6 \\ 8 & 7 \\ 9 & 8\end{array}$

$\begin{array}{ll}4 & 3 \\ 5 & 4 \\ 6 & 5 \\ 7 & 6\end{array}$

$\begin{array}{ll}2 & 1 \\ 3 & 2 \\ 4 & 3 \\ 5 & 4\end{array}$

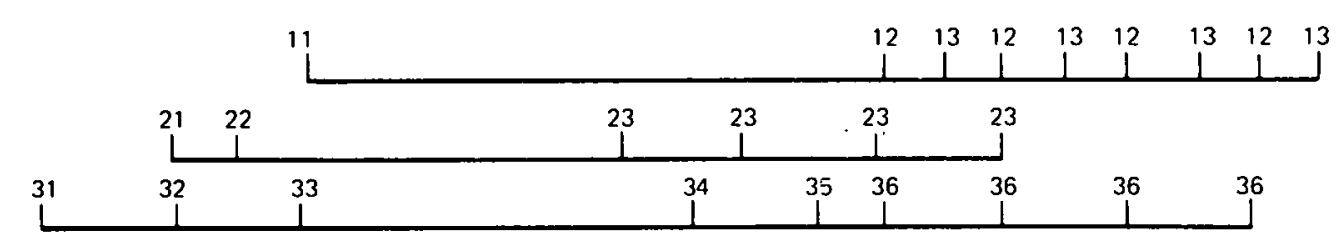

\begin{tabular}{lll}
41 & 42 & 43 \\
\hline
\end{tabular}

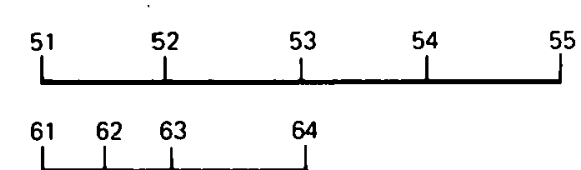

11: Construction permit issues, commence on-site construction. Corstruction complete, commence test

13: Commercial operation.

21: Resarve shop space.

22: Conmence shop fabrication.

Del very of equipment at site

31: File PSAR, commence NRC staff review

32: CP hearing.

33: Construction permit issues.

44: File FSAR, NRC staf: review.

36: OL hearing.

41: Applicant supp'ies required information.

commence review by NRC and

Departmen: of Justice.

42: Hearing, if required.
43: Antitrust issue resolved: $C P$ issues.
5.
Environmental review
6. Contractual arrangements

51: Environmental evaluation of candidate

52: Selection of principal site, in-depth environmental evaluation; prepare environmental reports, all necessary state

53: File applications.

54: Hearings.

55: All necessary environmental approvals. permits, certifications issue concurrently with NRC construction permit.

61: Engage architect-engineer, invite bids. Select manufacturer, determine size and

w. working arrangements.

63: Detailed engineering, prepare PSAR and

64: File PSAR and environmental applications. 
from future major backfitting requirements. As a result of the recent Three Mile Island (TMI) incident, substantial backfitting is required to upgrade the safety of the reactor systems.

\subsubsection{Plant outages}

Nuclear plants are subject to planned shutdowns for routine refueling and required inspection procedures, permitting some plant maintenance which may not be similarly afforded to fossil plants. On the other hand, nuclear plants are also subject to unplanned inspection outages as a result of faults found in similar reactors at other plants. These shutdowns are often relatively brief ( 3 to 6 days), but the frequency adds up to unexpected expenses in maintenance materials and offsite contract services. The procedures associated with plant outages, especially forced outages, are extremely demanding on plant personnel.

\subsubsection{Plant sécurlty}

Nuclear plants are required to prepare and implement security plans which meet the approval of the Nuclear Regulatory Commission (NRC). Considering the many recent occurrences of damage to both public and private property, it is expected that plant security will be upgraded for all plants.

\subsubsection{Housekeeping}

Housekeeping now involves two to three times as many people as was estimated when nuclear plants first entered commercial service. This work also requires closer supervision in nuclear plants.

\subsubsection{Training and licensing}

The NRC requires routine relicensing of reactor operators. To maintain in-plant training, a training department is often formed, and an extra shift of operators may be required to permit relief for training purposes. Training facilities for nuclear plants are now being provided by some of the larger utility companies. Since the TMI incident, significant emphasis has been given to improved operation training and stricter licensing requirements.

\subsubsection{Spare parts}

Approved quality assurance procedures are more stringent for purchasing, shipping, storage, and handling of spare parts in nuclear plants. Inventory requirements are higher for both nuclear and fossil plants because of longer lead times now required for delivery of critical items. The exchange of parts between utility companies when emergency repairs are needed is an important factor in reducing outage times.

\subsubsection{Environmental}

Meeting the guidelines of the Environmental Protection Agency (EPA) and other agencies regulating discharges to the environment requires onsite utility-company personnel.

\subsubsection{Personnel}

Personnel costs are increasing due to trends toward complete staffing for each unit, increasing turnover, and lack of interest in overtime and shift work. 


\subsubsection{Occupational Safety and Health Administration (OSHA) regulations}

OSHA regulations are primarily directed toward personnel safety, and equipment and systems are being modified to provide a safer working environment. Although some areas may benefit, it is expected that these measures will tend to increase the time required to perform O\&M functions.

\subsubsection{Fuel waste disposal}

The O\&M costs associated with meeting the demands for reduced radioactive waste releases from nuclear plants are dependent upon equipment requirements determined from a cost-benefit analysis of additional radioactive waste systems and equipment for reducing the radiation dose to the population reasonably to be expected within 50 miles of the reactor. ${ }^{7}$ The current trend is to process and store most radioactive wastes, as well as spent fuel at the reactor station or offsite.

\subsection{Unique Plant Features}

Each plant type has unique features which affect the nonfuel O\&M costs. Some important items are listed for each plant so that cost differences between the designs may be viewed in a broader perspective.

\subsubsection{PWR plants}

1. Boron shim control is required to supplement control rod regulation of reactivity.

2. Heavy-wall pressure vessels are difficult to open for servicing and refueling in existing plants. New designs should result in improved handling times.

3. Redundant auxiliary safety systems are required for emergency core cooling.

4. Primary system pressurizer operates at high pressure [13.8 M Pa (about $2000 \mathrm{psi}$ )].

5. Large heat exchangers are required for steam generation in a secondary system.

6. Turbine operates on saturated steam. Some designs use once-through steam generators which produce a very low degree of superheated steam.

7. Saturated-steam designs may incorporate full-flow demineralization of returned condensate in the future.

8. Radioactive waste systems employ special handling of steam generator blowdown (saturated-steam cases only).

9. Large heat exchangers are required to reheat high-pressure turbine ex haust steam prior to passage through the low-pressure sections.

\subsubsection{BWR plants}

1. Primary system supplies steam directly to turbine at about $6.89 \mathrm{MPa}(1000 \mathrm{psi})$.

2. A larger reactor vessel is required.

3. Steam supply system has fewer components but uses jet pumps and circulating pumps inside and outside the pressure vessel.

4. Direct cycle entails greater risks from radioactive leaks and contamination. An off-gas system handling the condenser ejector discharge is required. 
5. Redundant auxiliary safety systems are required for emergency core cooling.

6. Turbine operates on saturated steam.

7. Large heat exchangers are required to reheat high-pressure turbine exhaust steam prior to passage through the low-pressure sections.

\subsection{Nuclear Plant Costs}

The costs of both nuclear and fossil-fired power generating plants have been escalating at a steady rate since 1977 and will undoubtedly continue to do so in the future. Figure 14, prepared by the Department of Energy, indicates the recent and expected future costs of nuclear systems. As shown, the costs are expected to nearly double by 1988 . This is not unique to electrical generating systems, as other large plant (refineries, petrochemical plants, etc.) capital expenditures have, and are expected to follow a similar trend. Consequently, the advantages of using a nuclear dual-purpose plant for desalting are not expected to be altered significantly in the future.

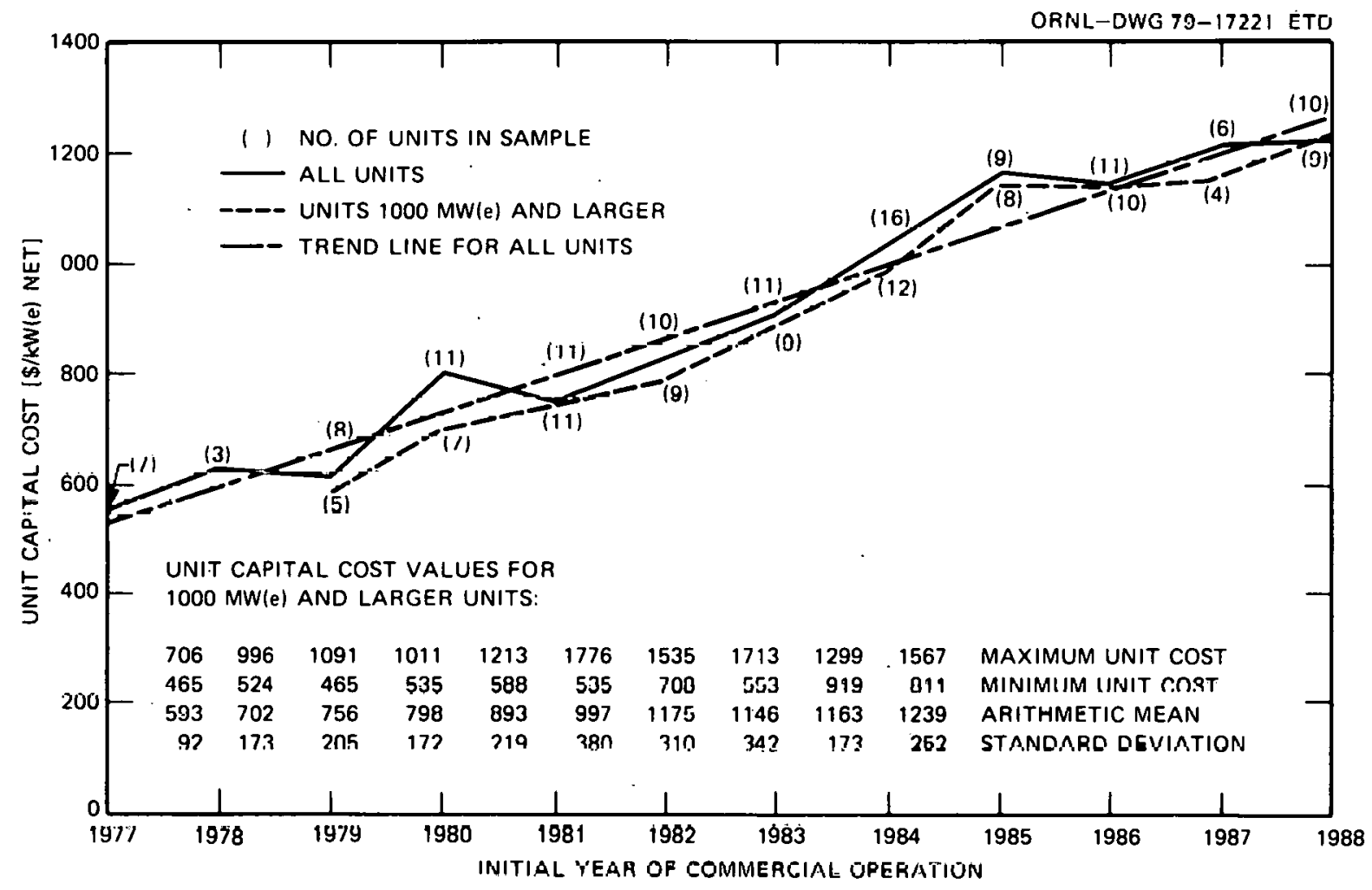

Fig. 14. Recent and expected future costs of nuclear systems. 


\section{DESCRIPTION OF DESALTING PROCESSES}

\subsection{Multistage Flash (MSF) Evaporation Process ${ }^{8}$}

\subsubsection{Operating principle}

Water will boil at progressively lower temperatures as it is subjected to progressively lower pressures. If a series of vessels (stages) are arranged as shown schematically in Fig. 15 and the pressure relationship $\mathrm{P}_{3}<\mathrm{P}_{2}<\mathrm{P}_{1}$ is maintained, then as preheated water is introduced into each stage in succession, part of the water will suddenly vaporize (flash) until the water temperature is again in thermodynamic equilibrium with the vapor pressure in that stage. As flashing occurs, the temperature of the brine decreases in an amount proportional to the quantity of vapor produced. As the vapors are flashed off the brine stream, its dissolved solids concentration increases and its temperature decreases.

Tubes carrying cooling water intercept and condense the water vapor. By using the cold-water feed as the cooling water, the greater part of this thermal energy is conserved.

\subsubsection{Process description}

The essential features and major components of an MSF plant are illustrated schematically in Fig. 16. The process can be divided into the four following streams.

1. Seawater Stream. The MSF process begins with cold raw water being pumped to the inlet of the heat rejection stages. The seawater is heated as it flows through the condenser tubes in these stages. After the seawater leaves the heat rejection section, a portion is returned to the sea. The remainder is chemically treated and flows to the decarbonator and the deaerator. In the decarbonator, the bicarbonate is converted to gaseous carbon dioxide and the greater part of this is vented; the deaerator removes oxygen and the remainder of the carbon dioxide from the makeup water.

2. Brine Recycle Stream. Upon leaving the deaerator, the seawater mixes with the concentrated brine leaving the last stage of the rejection section. Before mixing, a portion of the concentrated brine from the last stage is removed to waste to maintain the proper brine concentration. The mixture of concentrated brine and freshly treated makeup is then pumped to the last (coolest) stage of the heat recovery section of the evaporator. As recycle brine it flows through the tubes of the entire heat recovery section, receiving heat from the condensing product water and the reflashing distillate.

The recycle brine leaves the heat recovery section and enters the brine heater where it is further heated to its highest temperature. This additional heating is required to establish a flashing thermal potential. The top temperature of the brine is limited to avoid scale forming on the heater tubes. This depends on the type of feed water pretreatment used and the concentration range selected for the plant. 


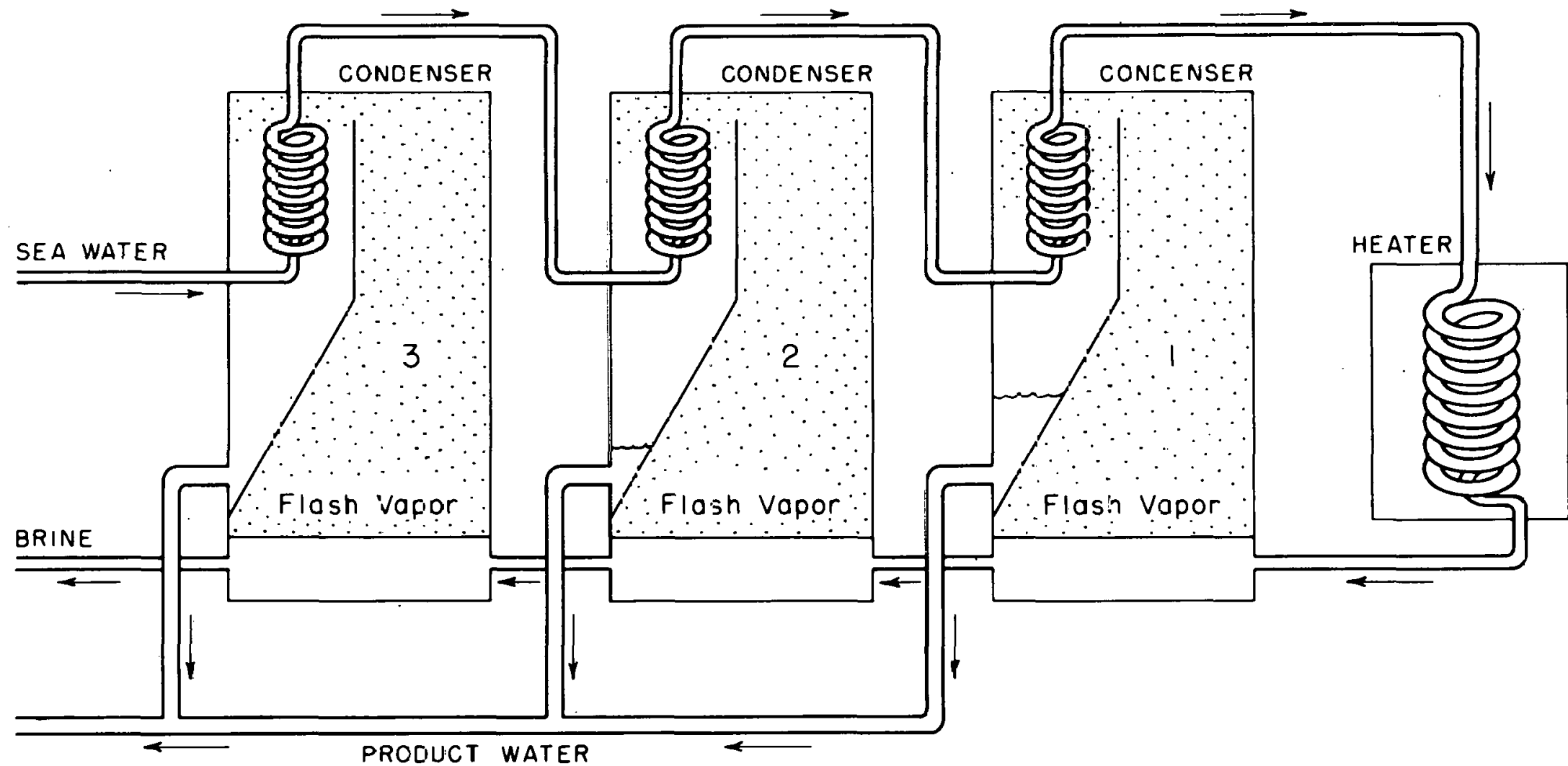

Fig. 15. Operating principle of the multistage flash distillation process. 
ORNI. DWG $77 \quad 14143$

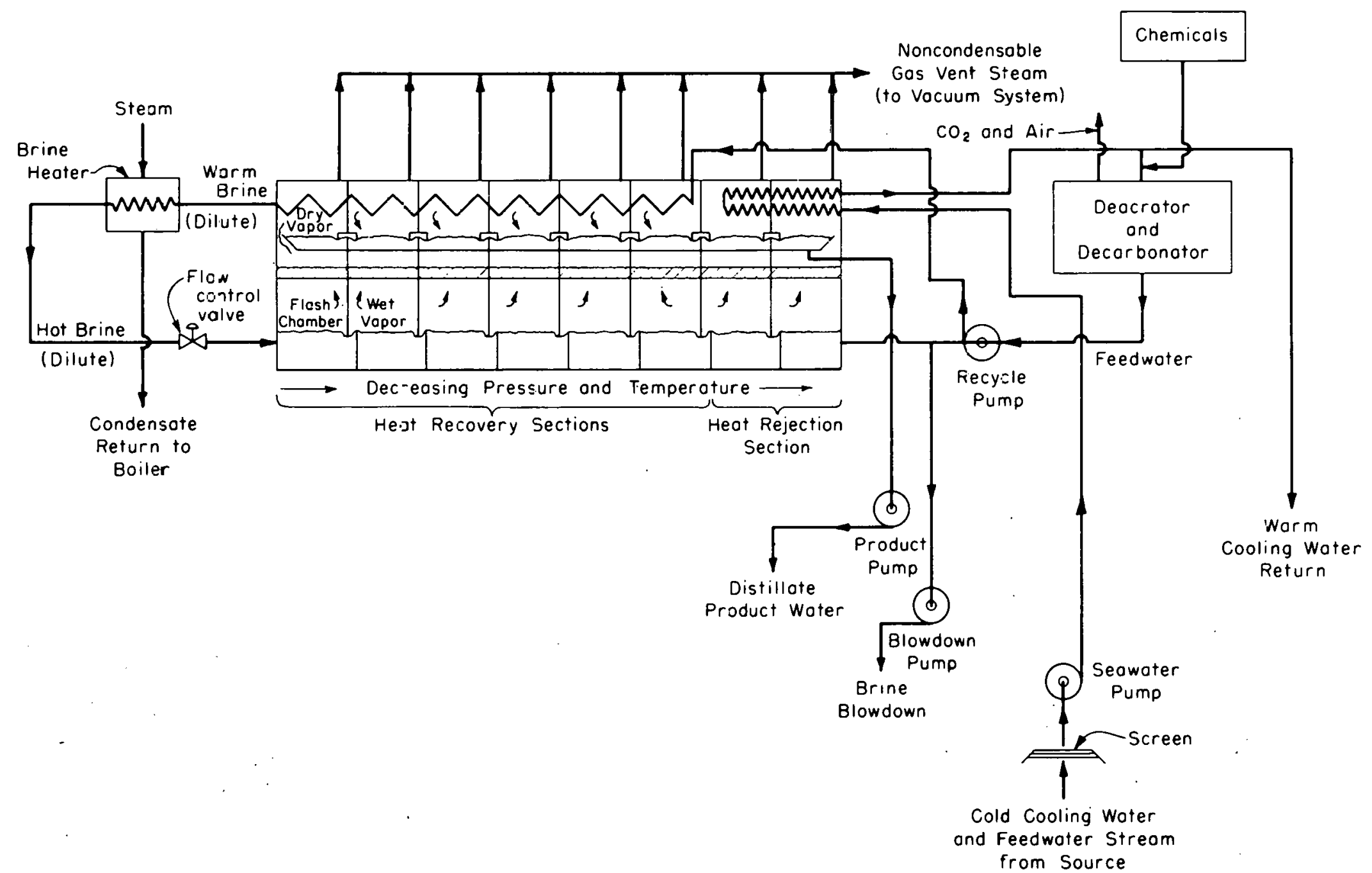

Fig. 16. Multistage flash distillation plant schematic. 
The brine leaves the brine heater and passes through a flow control valve. This valve maintains the brine pressure in the brine heater. The hot brine then is piped to the flashing chamber of the first (hottest) stage of the evaporator. A portion of the brine flashes to vapor. The vapor passes through entrainment separators (steam/liquid droplet separators) and condenses while transferring its latent heat of vaporization to the recycle brine flowing in the tubes of the heat recovery stage. The condensate (product) is collected in trays. The amount of vapor evaporated and the brine saturation pressure in the stage are determined by the condensation rates.

As the brine flashes, it cools and then passes through flow control devices such as orifices or weirs, into the next lower pressure stage. The flashing process continues at progressively lower pressures until the brine reaches the last stage of the heat rejection section. The concentrated brine leaves the last stage, after which a portion is removed as blowdown, and the balance is returned to the suction side of the recycle pump. In some plant arrangements, termed once-through plants, all of the last stage brine is blown down and none of it is recycled.

3. Product Water Stream. The distillate produced from the condensing vapor flows along in trays, gradually increasing in volume until it leaves the last stage. It is then directed to the product water pump which pumps the product stream to the desired location. As the product flows from stage to stage, its temperature is reduced by flashing to a lower pressure in a manner similar to the brine stream. In some MSF plants, the product is sent to a product water cooler where its temperature is reduced to the 24 to $27^{\circ} \mathrm{C}$ ( 75 to $\left.80^{\circ} \mathrm{F}\right)$ range.

4. Vapor Streams. There are two major vapor streams. They are the steam admitted to the brine heater and the vapor resulting from liquid flashing in each stage. Condensate from the brine heater usually is returned to the boiler, while condensate originat ing from flashing becomes the product water.

A minor vapor stream, with respect to sizc only, vents the noncondensable gases which must be removed from the stages to maintain design production rates, temperatures, and pressures. Noncondensable gases are essentially air and carbon dioxide liberated during the evaporation process. It not removed, they impede the transfer of heat and reduce the desalting plant's capacity.

\subsection{Vertical Tube Evaporation (VTE) Process}

This process was formcrly known as the long tube vertical (LTV) process and is in direct competition with the MSF process for seawater desalting. Recent studies have indicated there is a substantial saving in energy cost when combining the VTE process with the MSF process.

\subsubsection{Operating principle}

Like MSF, this process operates on the principle that water boils at progressively lower temperatures when introduced into vessels (effects) which are maintained at successively lower pressures. In the MSF process, vapor produced in any stage is used in that stage to preheat incoming seawater. In the VTE process, vapor produced in one effect is condensed in the next effect to produce more vapor (Fig. 17). The tubing in the VTE process has a vertical configuration as contrasted with the horizontal arrangement of the tube bundles in the MSF process. These two factors demonstrate the most basic differences in these processes. They lead to some thermodynamic and heat transfer advantages being claimed for the VTE process. 
ORNL OWG $\gg 14139$

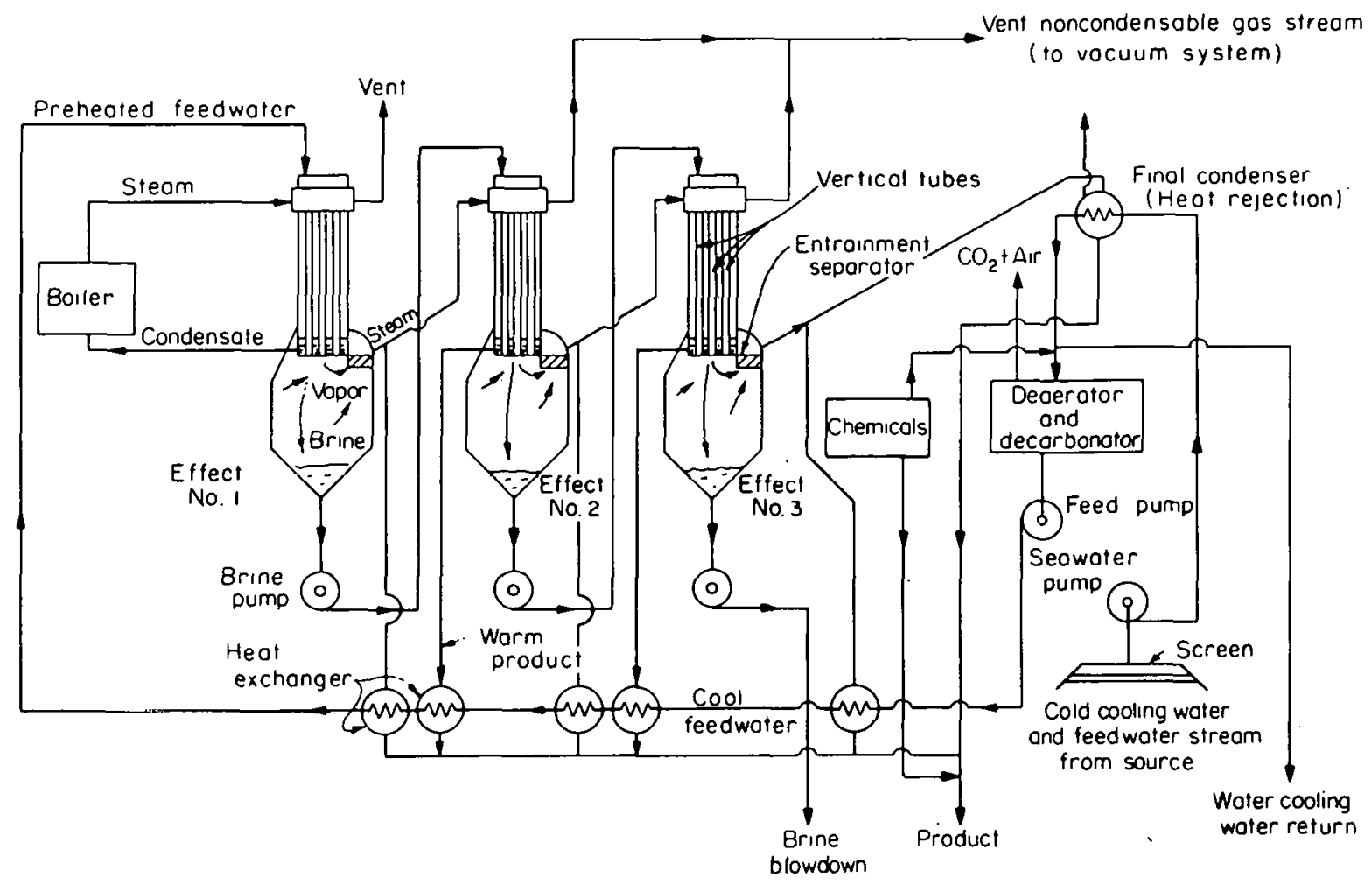

Fig. 17. Vertical tube evaporation process schematic.

\subsubsection{Process description}

The diagram shown in Fig. 17 illustrates the VTE process. Seawater feed falls though a bundle of vertical tubes located inside a large chamber. As the seawater falls through the tubes, it is heated by steam which surrounds the tubes. This heat exchange operation converts some of the water from the saline solution inside the tubes into steam, and, at the same. time, condenses some of the steam which surrounds the tubes into freshwater.

To obtain high efficiency in the use of heat energy, the process is repeated in several evaporator units, called effects. These effects are arranged in series. The steam for the first effect is supplied by a steam generator plant, and the water condensed from that steam is returned to the steam generator. Steam produced inside the tubes of the first effect flows to the second effect where it surrounds the second bundle of tubes. The brine that did not vaporize in the first effect enters at the top of the second effect and flows downward through the second tube bundle. The steam which surrounds the tubes heats the brine as it falls, converting some of the water inside the tubes into steam. and condensing some of the steam outside of the tubes into freshwater.

This process is repeated through several effects. The temperature of the saline water drops as it progresses through the series of effects. The pressure in each effect is also progressively reduced to permit vaporization to occur at lower temperatures. The brine which collects at the bottom of the last effect is discharged. 
The remaining features shown in the figure have similar functions as in the MSF process. Pumping energy is required to drive the various process streams. Chemicals must be added to the saline water feed to prevent scaling. Deaeration and decarbonation are required to minimize corrosion and scaling problems. Noncondensables must be vented properly or heat transfer will be seriously affected, and product passivation is required since the process also produces an extremely pure product water.

Later innovations included the design of hybrid processes incorporating both VTE and MSF technology. In this process (see Fig. 18) the MSF portion of the plant acts as a preheater for the brine feed to the VTE plant. ${ }^{9}$ Such configurations lead to lower product water cost due to improved thermodynamic efficiency, lower brine pumping costs, and the ability to combine the VTE and MSF stages so that they have common structural elements and containment walls.

RRNI $=$ DWI $7 ?-11110$

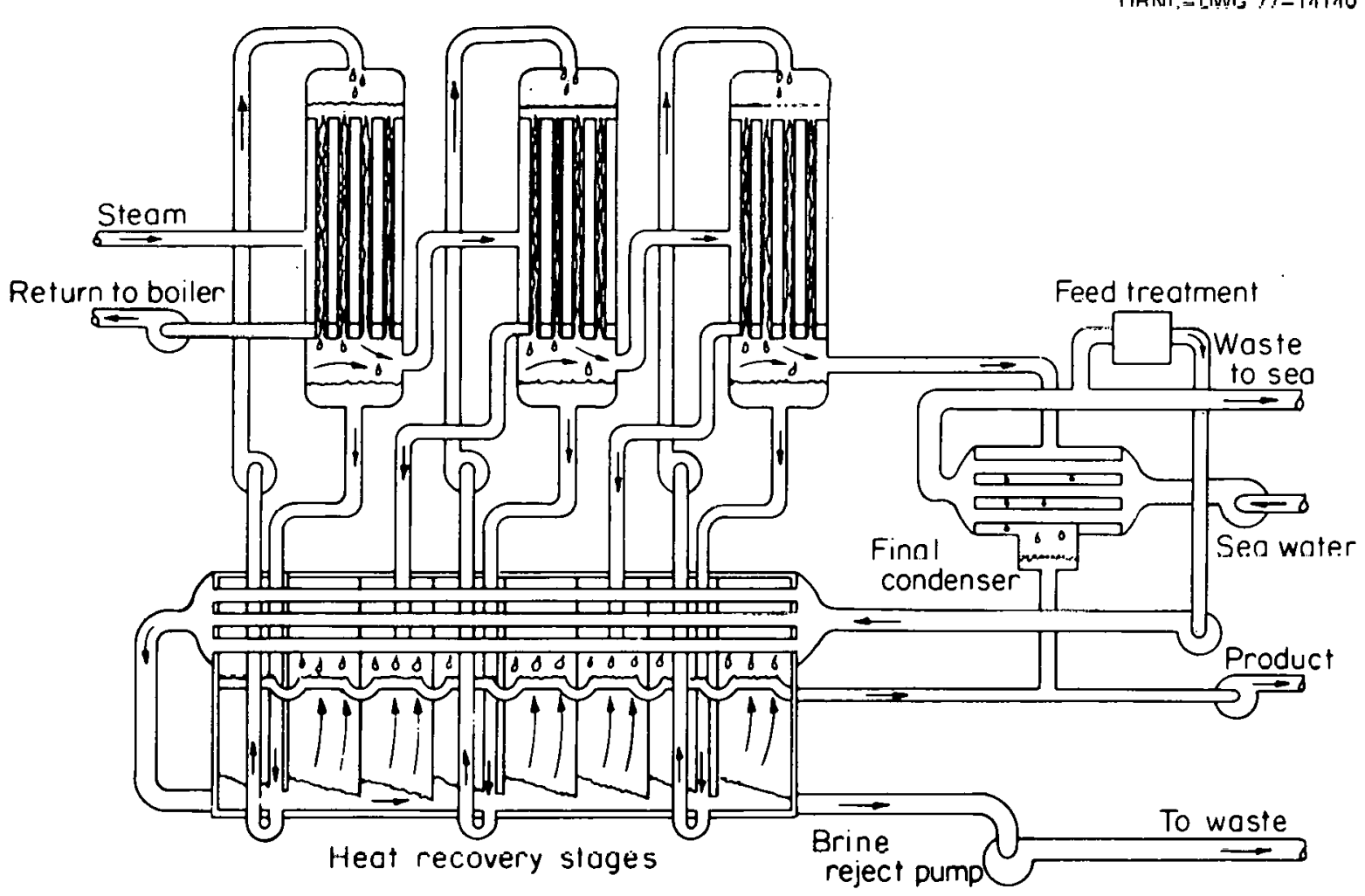

Fig 18 Combingtion VTE-MSF proeess.

\subsection{Multipffẹt Multistage (MEMS) Flash Process}

\subsubsection{Operating principle}

This process has been developed from the MSF process discussed previously. It incorporates the principles of the MSF as well as the multiple effect technique.

\subsubsection{Process description}

Figure 19 shows schematically how the MEMS process uses three MSF modules in a triple effect arrangement. The heat rejected from the first effect is used for the top temperature boost of the brine in 
ORNL-OWG 77-14141

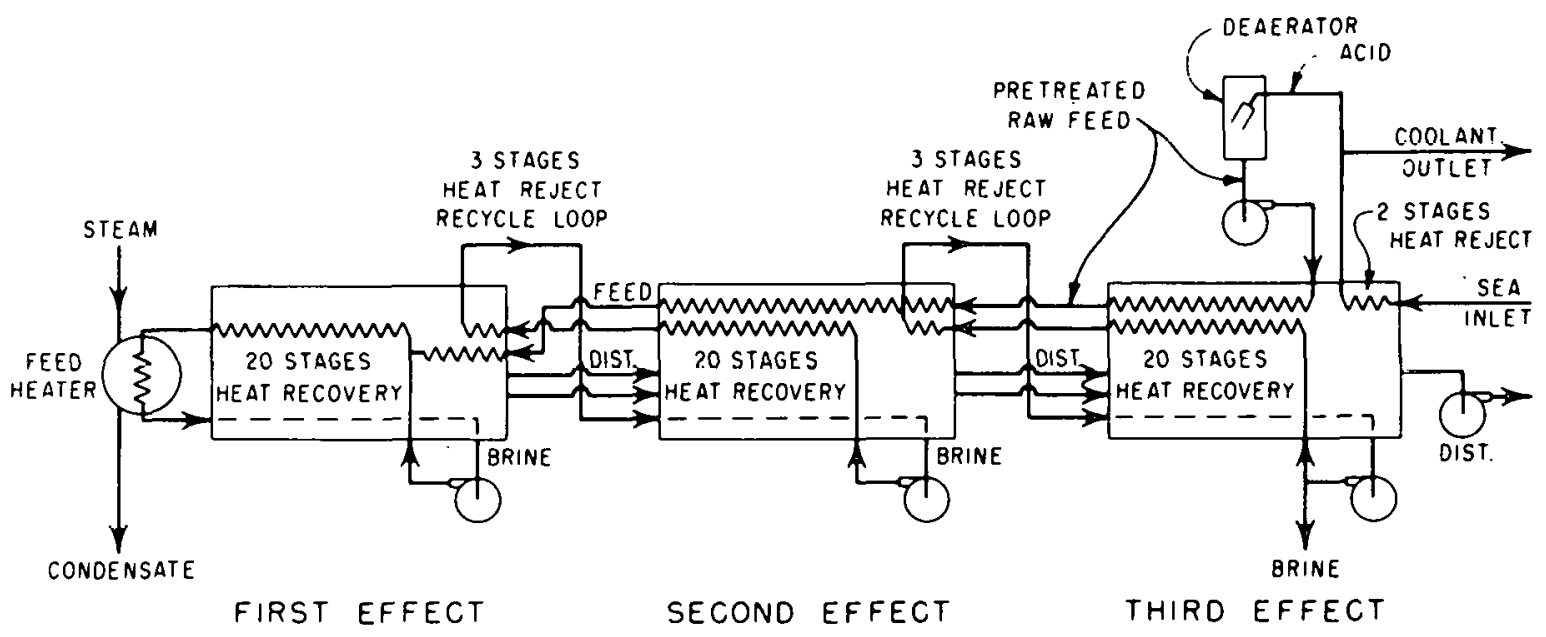

Fig. 19. Schematic diagram of the multieffect multistage distillation process.

the second effect and so on. The final heat rejection is from the third effect. The arrangement in effects has two distinct advantages. It allows the flashing stages to be designed for a better use of the total available temperature difference. Furthermore, it also allows a higher maximum temperature in the first effect without aggravating the calcium sulfate scaling problems, since the brine concentration in this effect is now considerably lower than the waste brine concentration.

Another multieffect process is presently being developed under a joint United States/Israel cooperative program. ${ }^{10,11}$ The process incorporates the falling film, multieffect evaporation principle with horizontal tubular aluminum alloy heat transfer surfaces. To inhibit alkaline scale formation in the plant as the seawater is being heated to its maximum temperat ure, the seawater feed is typically treated with 3-5 ppm of polyphosphate. As shown in Fig. 20 , the feedwater at $18.6 \mathrm{kPa}(5.5 \mathrm{in} . \mathrm{Hg})$ back pressure is then heated by process steam to a maximum temperature of $70-72^{\circ} \mathrm{C}\left(158-162^{\circ} \mathrm{F}\right)$ as it is introduced into the top of the first effect and flows by gravity over the outside surfaces of each tube. The brine is distributed uniformly over the tubes by means of spray nozzles.

In each effect the $3.8 \mathrm{~mm}(0.15 \mathrm{in}$.) O.D., $18 \mathrm{BWG}$ aluminum alloy tubes are held in place and seated to a tube sheet at the vapor inlet end using "O"-ring type seals. The downstream ends of the tubes are supported by an open lattice-work grid which offers a minimum resistance to vapor flow. The tubes are slightly inclined to promote condensate drainage. The upstream ends are open while the downstream ends of each tube are restricted by an orifice which has a hole from which noncondensable gases are vented. Vapors to a succeeding effect are drawn into the tubes from the preceding effect by the pressure differential created by their condensation in the tubes. The thermal driving force for condensation within the tubes and evaporation outside the tubes is provided by the pressure and temperature differential between effects. Noncondensable gases accumulating within the tubes pass through the bleed orifices at the ends of the tubes and are cascaded sequentially to the following downstream effects and final condenser at which point they are extracted from the plant. The process operates at a performance ratio (PR) of $8-10 . *$

*Performance ratio (or gain ratio) $=0.4 \mathrm{~kg} / \mathrm{kJ}$ (lbs of product $/$ loon Bt 1 ) of hear inputr. 


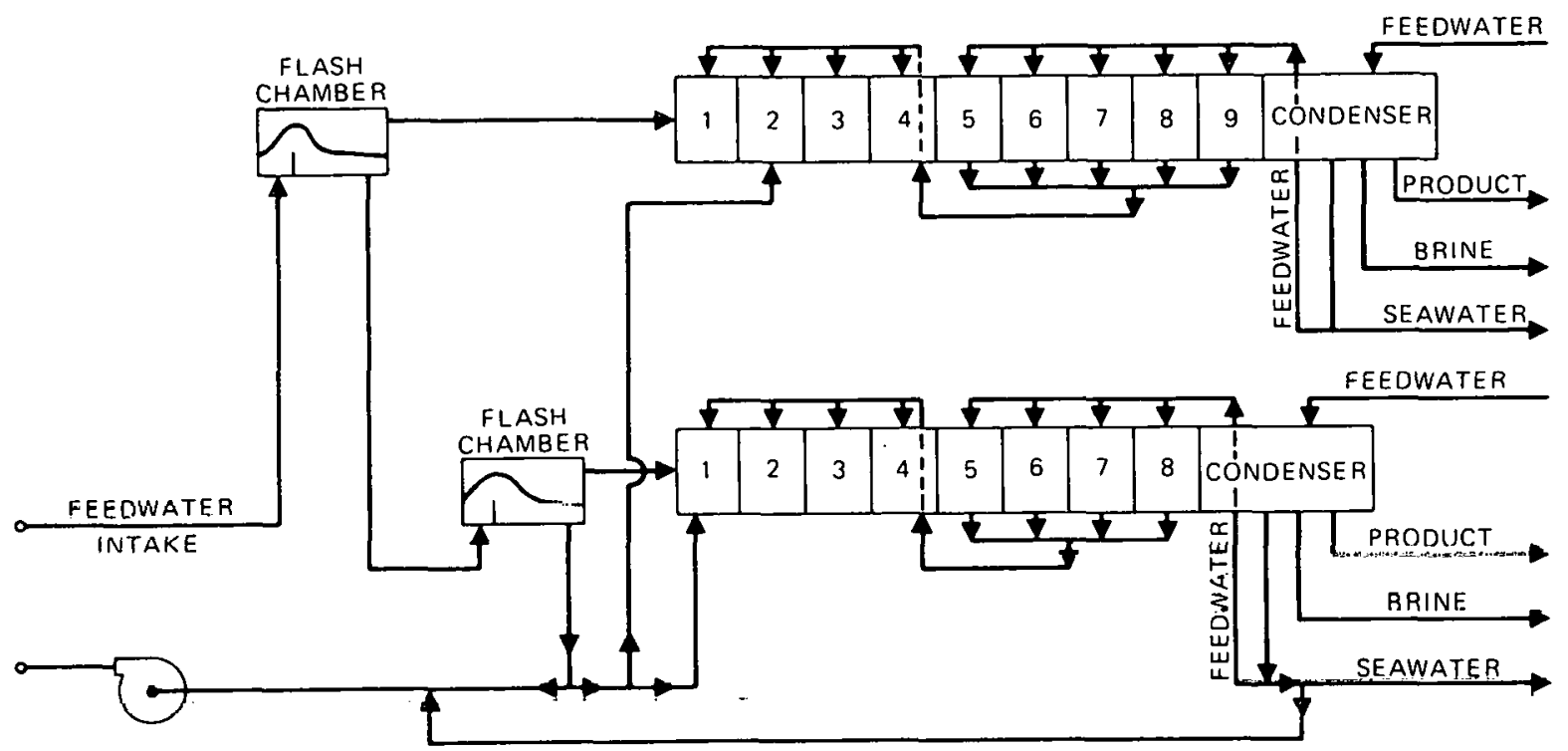

Fig. 20. Schematic diagram of the multieffect evaporator being developed in the United States/Israel joint program.

This plant design incorporates one innovative feature which makes it particularly attractive for coupling to a nuclear steam source. Because of the possibility of potential contamination being carried in the nuclear steam exhausted from the turbine to the desalination plant, some means must be taken to prevent such an occurrence. In this design, the steam exhausted from the turbine is condensed in a conventional power plant condenser instead of the brine heater as would be done in a fossil-fired plant. Instead of being cooled by normal seawater, the condenser is cooled by a concentrated brine from the desalting plant at a temperature of $51.5^{\circ} \mathrm{C}$ or $56.8^{\circ} \mathrm{C}\left(125^{\circ} \mathrm{F}\right.$ or $\left.135^{\circ} \mathrm{F}\right)$ depending on the allowable back pressure of the turbine. This brine heats up by about $50^{\circ} \mathrm{C}\left(122^{\circ} \mathrm{F}\right)$ while passing through the condenser tubes, and by doing so condenses the steam outside the tubes. From the outlet of the condenser, the warmer brine is directed to a flash chamber, where a lower pressure exists. Part of the brine flashes into steam, and by doing so cools down by about $50^{\circ} \mathrm{C}\left(122^{\circ} \mathrm{F}\right)$ and returns to the condenser after a certain blow down of the concentrate and addition of make up brine. The steam generated in the flash chamber moves to the inside of the aluminum tubes of the first effect of an evaporator plant, where it condenses. the condensate being part of the product water. 


\section{SEAWATER PRETREATMENT}

\subsection{Feedwater Quality}

The quality of feed water to a desalting plant can significantly affect the process operation and the performance of materials of construction used in the plant. Entrained sand, shells, etc., can result in undue erosion of pumps, valve internals, pipe bends, and the most commonly used heat transfer tubing materials. Similarly, rapid localized erosion in heat transfer tubes can be caused by foreign objects such as shell fragments, which partially plug tubes. Sewage, certain industrial wastes, and decaying organic matter (e.g., seaweed or coral) which might liberate hydrogen sulfide, ammonia, or other corrosive gases, can bring about unanticipated corrosion or fouling problems. Thus, in selecting a location to site a feedwater intake structure, it is prudent to consider what future pollutants might be introduced into the vicinity of the plant, as well as the present chemical makeup of the feedwater source.

\subsection{Scale Control and Concentration Ratio}

As feedwater enters the intake structure, it first passes through trash rakes (bar screens) and rotating screens to remove debris, shells, etc., and is then treated to control scale formation and organic fouling.

The major scaling constituents in seawater are calcium bicarbonate and magnesium hydroxide, the so-called alkaline scales, and calcium sulfate which can exist in three forms, gypsum $\left(\mathrm{CaSO}_{4} \cdot 2 \mathrm{H}_{2} \mathrm{O}\right)$, hemihydrate $\left(\mathrm{CaSO}_{4} \cdot 1 / 2 \mathrm{H}_{2} \mathrm{O}\right)$, and anhydrite $\left(\mathrm{CaSO}_{4}\right)$. When untreated seawater is heated above $\sim 77^{\circ} \mathrm{C}\left(170^{\circ} \mathrm{F}\right)$, the calcium bicarbonate slowly decomposes and carbon dioxide is liberated. As carbon dioxide gas evolves, seawater becomes more alkaline, and calcium carbonate and magnesium hydroxide can precipitate to form tenacious scales which foul the heat transfer tubing and other internals of an evaporator.

Depending upon the maximum operating temperature desired, one of several feed water treatment schemes may be used. Many of the commercial MSF plants in use today are operated at a maximum brine temperature no greater than 88 to $91^{\circ} \mathrm{C}\left(190\right.$ to $\left.195^{\circ} \mathrm{F}\right)$. At these conditions it is common practice to inject one of the available proprietary phosphate-based chemical compounds (e.g., Hagavap, Brovap) into the seawater feed stream at a dosage of 3 to $6 \mathrm{ppm}$ (parts per million parts by weight). These materials effectively sequester the alkaline scales to form a nonadherent sludge, which is suspended in the flowing brine and is discharged in the brine blowdown stream. These polyphosphate materials also produce an alkaline environment in the evaporator which generally rctards corrosion of steel and other materials of construction. A film of the sludge does gradually foul the heat transfer surfaces in the plant and is removed periodically by flushing the plant with acid. During this period of 
acid cleaning, corrosion problems sometimes develop. Some plants employing polyphosphate feed treatment operate once-through, others recycle a part of the brine. With polyphosphate treatment the concentration ratio (CR) is limited by the total dissolved solids content (TDS) of the feedwater, since the blowdown brine concentration should not exceed $\sim 80,000$ ppm TDS.

Often an alternate scheme, "acid dosing," is used to control such formation. For operating temperatures up to $121^{\circ} \mathrm{C}\left(250^{\circ} \mathrm{F}\right)$, the common scheme involves neutralizing the bicarbonate alkalinity by injection of a mineral acid, usually $98 \%$ sulfuric acid or, less frequently, hydrochloric acid, into the makeup feed of a brine recirculation type plant. To neutralize the alkalinity, a stoichiometric quantity of acid is used (115 to $120 \mathrm{ppm}$ for normal seawater, $\sim 140 \mathrm{ppm}$ for the Arabian Gulf). The gaseous carbon dioxide $\left(\mathrm{CO}_{2}\right)$ resulting from the reaction must subsequently be stripped from the feedwater to avoid gas blanketing of heat exchanger bundles and to mitigate corrosion. Some plant operators acid dose to achieve $\mathrm{pH}$ values as low as 4.5 to speed the reaction of the bicarbonate with acid. In such cases, after decarbonation, caustic is then added to provide a near neutral $\mathrm{pH}$ to minimize corrosion. With acid treatment, an evaporator operating on standard seawater may be operated for sustained periods at $121^{\circ} \mathrm{C}\left(250^{\circ} \mathrm{F}\right)$ and $\mathrm{CR}=2$ without scale formation. Inherent disadvantages of this scale control treatment are the inadvertent loss of $\mathrm{pH}$ control with the result being rapid corrosion of evaporator construction materials, and the hazards associated with shipping, handling, and storing large volume of a highly corrosive solution.

Calcium sulfate scales are rarely encountered in currently operating MSF plants unless a plant malfunction occurs. As shown in Fig. 21 , the solubility diagram for the three species of calcium sulfate

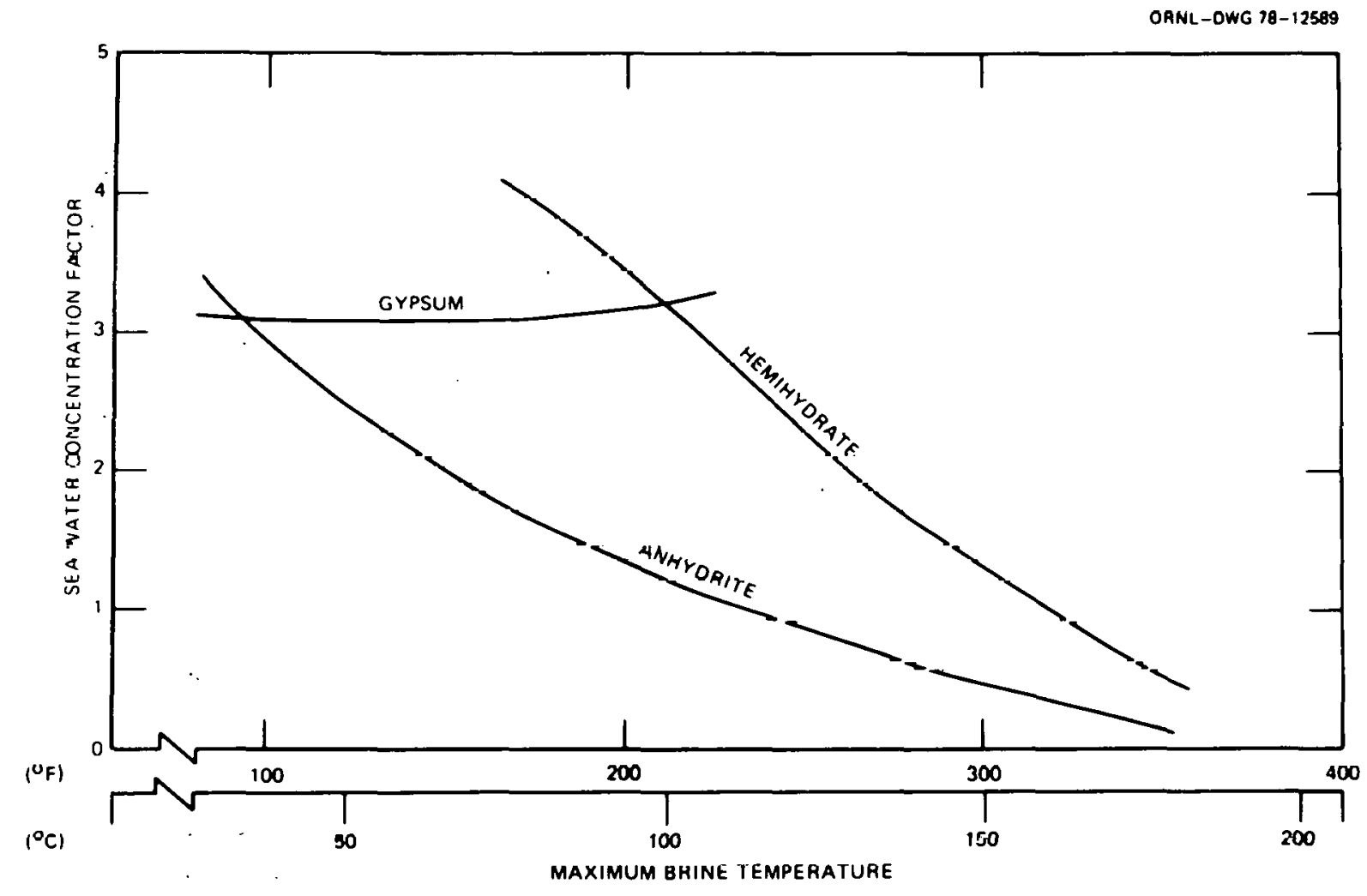

Fig. 21. Solubility diagram of the calcium sulfate in seawater. 
would indicate that fouling by anhydrite scale would occur below $121^{\circ} \mathrm{C}\left(250^{\circ} \mathrm{F}\right)$ and $\mathrm{CF}=2$, the normal operating range for an acid treated MSF plant. However, because of the favorable kinetics of the system, the anhydrite solubility line may be breached and it is the hemihydrate which precipitates first as scale.

\subsection{Corrosion Control}

The principal means of controlling corrosion of the materials of construction of an MSF plant are to reduce the dissolved oxygen and carbon dioxide in the feed water to the lowest practicable concentrations and to control the $\mathrm{pH}$ of the circulating brine to produce a neutral or alkaline brine. There is suitable instrumentation available for on-line monitoring of $\mathrm{pH}$, oxygen, and temperature of the various process streams. Noncondensable gases which are released or leak into subat mospheric stages must be vented from the tube bundles to minimize corrosion and to prevent gas blanketing of the bundles. Entrainment of sand and shell fragments and other debris in the feedwaters should be eliminated to prevent corrosion/erosion. Of utmost importance are process chemistry control, proper selection of materials of construction for the various plant components, attention to the galvanic potentials of metals in contact with each other, and elimination of areas of high turbulence.

\subsection{Deaeration and Decarbonation}

In once-through polyphosphate-dosed plants, the noncondensable gases are removed as the brine flashes in the first two or three stages of the evaporator and are then vented to the vacuum system. The release of gases in the high temperature stages is quite violent, and much foaming occurs. Consequently, an agent is required to prevent formation of light weight brine foam which can be carried by the flashed water vapors. Most proprietary polyphosphate preparations contain an antifoam agent.

In plants employing polyphosphate treatment and brine recycle, noncondensable gases may be removed in the heat rejection stages of the evaporator.

In acid treated plants, where significant quantities of $\mathrm{CO}_{2}$ are liberated due to decomposition of the bicarbonate alkalinity, it is common practice to partially remove the $\mathrm{CO}_{2}$ in an atmospheric decarbonator. Decarbonation reduces considerably the load on the vacuum deaerator and results in significant savings in steam cost when steam jet ejectors are used to provide the vacuum.

Decarbonation is followed by vacuum deaeration which may be carried out in the final stages of the evaporator or in a separate vessel. A well designed and operated vacuum deaerat or with countercurrent steam stripping will lower the dissolved oxygen to $\sim 0.1 \mathrm{ppm}$ and carbon dioxide to $\sim 1 \mathrm{ppm}$. Normally, the residual oxygen is scavenged by injecting sodium sulfite downstream of the deaerator at a dosage rate slightly above the stoichiometric requirement.

In addition to the conventional polyphosphate and acid scale control methods, several other schemes have been tested or are currently undergoing field trials. One promising material is Belgard EV,* a polymeric carboxylic acid which is a dry powder that can be mixed with water on site. Depending on the quality of the feedwater, dose rates of 6 to $8 \mathrm{ppm}$ have reportedly prevented scale formation and reduced corrosion of iron and copper-based alloys on acid-dosed plants originally designed for temperatures to $121^{\circ} \mathrm{C}\left(250^{\circ} \mathrm{F}\right)$ and concentration ratios to 2 . These observations were made during field tests on various evaporators throughout the world. In general, the test periods have been of relatively short duration, 1 year. ${ }^{12}$ At these dosage rates, the $\mathrm{pH}$ of the brine ranged from 8.5 to

* Belgard EV is manufactured by Ciba-Giegy Plastics and Additives Company. 
10 , a pH regime where precipitation of magnesium hydroxide can be expected. Accordingly, some tests have been carried out with mixtures of Belgard EV and sulfuric acid. ${ }^{13}$ Continued testing is underway at various sites in the Middle East and North Africa.

If there is an incentive to operate an MSF plant at temperatures above $121^{\circ} \mathrm{C}\left(250^{\circ} \mathrm{F}\right)$ and/or concentration ratio greater than 2 , one must remove a portion of the calcium and/or sulfate from the seawater. The major incentives for going to higher temperatures and concentration ratios (CRs) are to reduce the heat transfer surface cost, to increase the performance ratio because of high fuel cost, or to produce some beneficial byproduct from the feedwater, for example, a fertilizer material.

The lime magnesium carbonate (LMC) process will remove $70 \%$ or more of the calcium content of seawater. The process, based on the flowsheet shown in Fig. 22, was successfully demonstrated in conjunction with the Clair Engle Plant I A effect, at the Office of Saline Water San Diego Test Facility at brine heater temperatures to $177^{\circ} \mathrm{C}\left(350^{\circ} \mathrm{F}\right) .^{14-16}$

ORNL-OWG 78-1258̣6

\section{RAW SEAWATER}

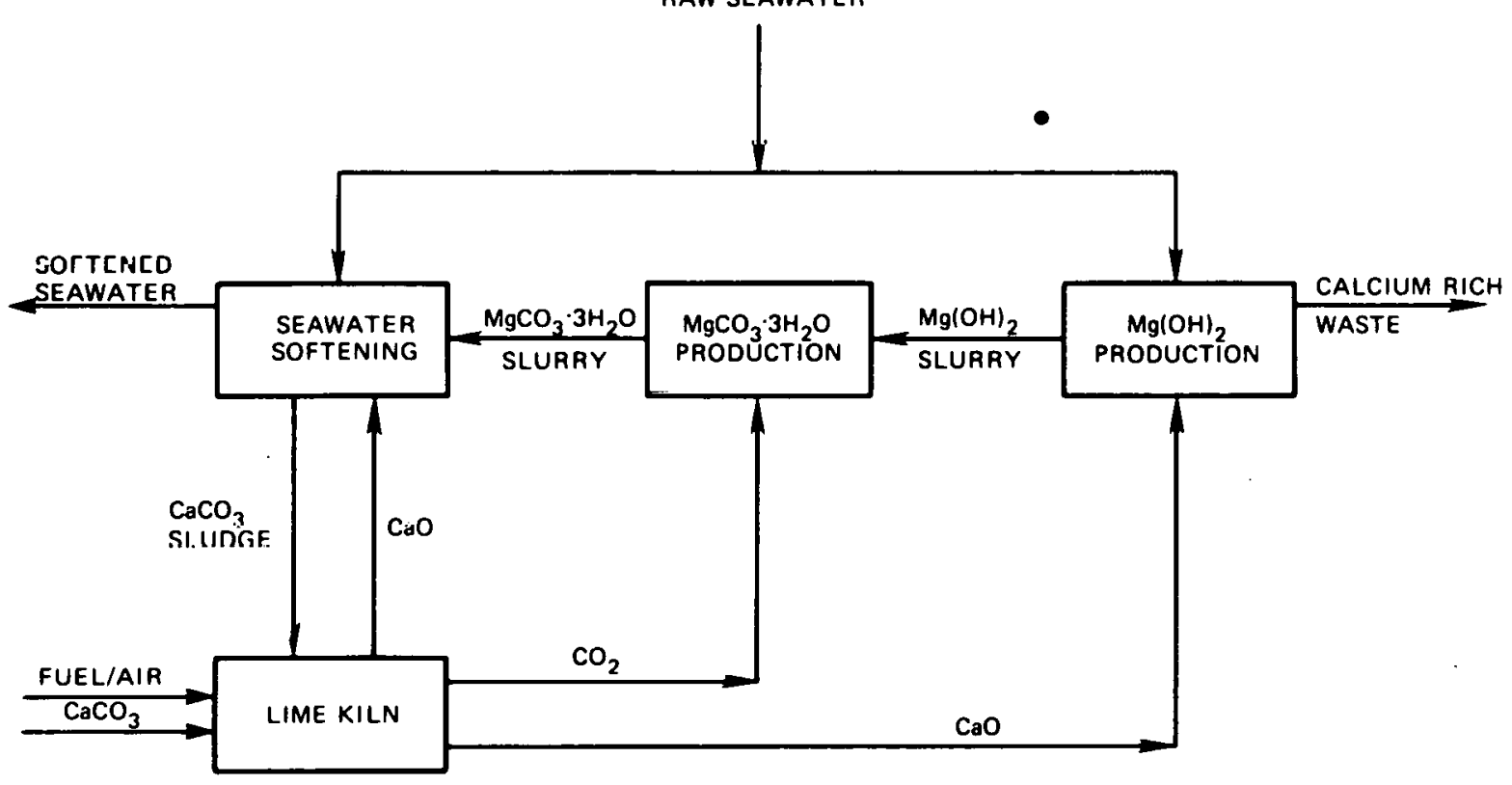

Fig. 22. Schematic diagram of the lime-magnesium carbonate process.

Another process which can be used to reduce the scaling potential of concentrated seawater produces a high grade fertilizer containing many trace elements essential for good plant growth. ${ }^{1 "}$ The process involves treating seawater with phosphoric acid (or sodium phosphates) and ammonia to remove $\sim 99 \%$ of the magnesium and $\sim 95 \%$ of the calcium contained in seawater to produce a fertilizer containing $7 \% \mathrm{~N}, 44 \% \mathrm{P}_{2} \mathrm{O}_{5}, 21 \% \mathrm{MgO}$, and $5 \% \mathrm{CaO}$, plus trace elements. After such treatment the seawater may be concentrated to ten times normal seawater concentration without scale formation.

Another process which was carried through pilot plant tests at $280 \mathrm{~m}^{3} / \mathrm{day}(75,000$ gal/ day) was the lon Exchange Desulfating process. The process shown schematically in Fig. 23 is based on the removal of sulfate from seawater using a cation exchange resin in the barium form. ${ }^{18}$ The resin is regenerated and returned to the cycle on a continuous basis. Effluent from the desulfating process 


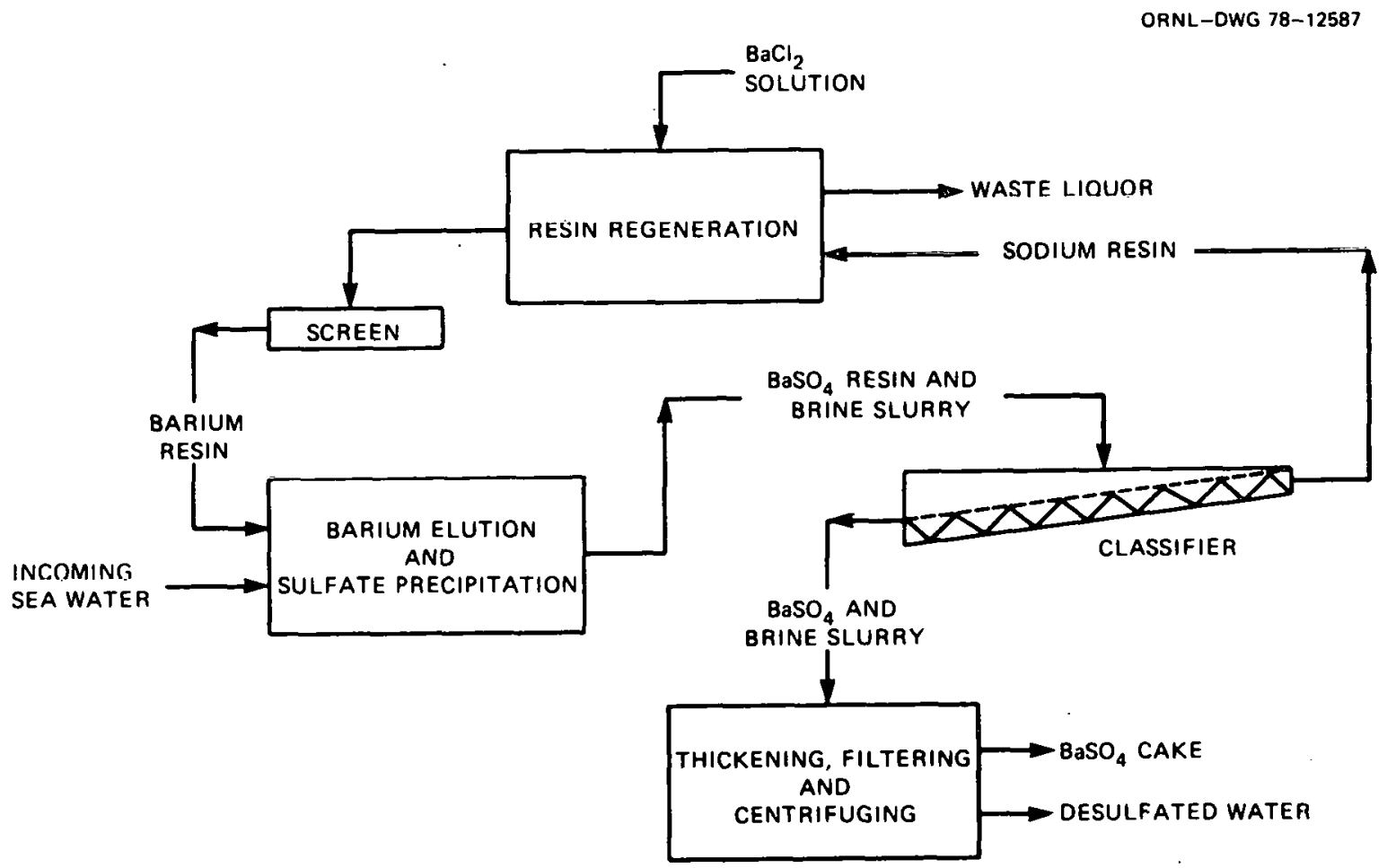

Fig. 23. Schematic diagram of the ion exchange desulfating process.

which contained $44 \mathrm{ppm} \mathrm{SO}_{4}$ (as compared to $\sim 2580 \mathrm{ppm}$ in the seawater influent) was run in a pilot evaporator at $177^{\circ} \mathrm{C}\left(350^{\circ} \mathrm{F}\right)$ at a concentration ratio of 2.8 without scale formation.

Other pilot plant studies have been made using cation exchange resins to remove calcium from seawater using blowdown brine as a regenerant. ${ }^{19-24}$ Removal of $65 \%$ of the calcium from seawater would raise the maximum scale-free operating temperature to $149^{\circ} \mathrm{C}\left(300^{\circ} \mathrm{F}\right)$ at a blowdown $\mathrm{CR}$ to 4.7 . Removal of $50 \%$ of the calcium would allow operation at $135^{\circ} \mathrm{C}\left(275^{\circ} \mathrm{F}\right)$ and a $\mathrm{CR}$ of 4 .

The scaling constituents of seawater may also be removed by contacting the heated seawater with a slurry of mixed seed crystals of the scale forming compounds [ $\left.\mathrm{CaCO}_{3}, \mathrm{Mg}(\mathrm{OH})_{2}, \mathrm{CaSO}_{4}\right],{ }^{25}$ Precipitation takes place preferentially on the seed crystals rather than on the metallic surfaces of the evaporator. This procedure is also known as the contact stabilization method.

All of the processes for descaling feedwater for operation of an evaporator above $121^{\circ} \mathrm{C}\left(250^{\circ} \mathrm{F}\right)$ and $\mathrm{CR}=2$ would require reevaluation to determine their suitability and economics for specific sites.

Based on the data available, Belgard EV appears to be a likely substitute for acid. However, additional data are needed on its effectiveness during extended periods of operation and when there are temperature excursions above $121^{\circ} \mathrm{C}\left(250^{\circ} \mathrm{F}\right)$. A design fouling fact or must be established while using Belgard before a large tube bundle can be designed with confidence. These data should he obtained using feedwater from the site that has been selected for the MSF plant.

\subsection{Organic Control}

In addition to proper screening to prevent mollusks, jelly fish, and other marine animals from entering the plant, microorganisms which form slimes and other marine organisms which may plug or 
foul equipment must be killed. This is normally done by chlorinating the feedwater, either continuously or intermittently. The chlorine may be generated in situ (as hypochlorite) by electrolytic decomposition of seawater, or by using commercially produced chlorine, which is shipped to the site in suitable containers. The chlorine demand varies with the feedwater quality, the time of year, the plant site, etc., but usually such organisms will be kept under control by maintaining $0.5 \mathrm{ppm}$ residual chlorine in the feed stream. Chlorine is usually added at the seawater intake. There are readily available instruments for adding and monitoring chlorine injection.

\subsection{Evaporator Components}

\subsubsection{Evaporator shells}

The evaporator shells of existing desalting plants are of metal, usually carbon steel, either bare or lined for corrosion protection.

Corrosion is a problem in these existing plants. Shells are designted will cuirosion allowances to prevent structural failure, but products of corrosion impair evaporator efficiency. Water boxes and steam chests are particularly vulnerable to corrosion problems. Corrosion effects on shells occur as localized (spot) tailures which cause leakage but no dangerous luss of siluctuial sliciglh, luigelicin general internal vacuum cannot be maintained or structural integrity may be impaired.

Corrosion of carbon steel is controlled by feedwater treatment, by deaeration, and by interior coatings. Coatings such as special cement mortars or epoxy (or similar) furnish successful protection unless penetrated. After penetration, the corrosion of the underlying structural metal is similar to an un protected shell, with the additional problem of break-up of adjacent coating which may block water openings in the MSF stages. More success has been achieved through use of type 300 series stainless steels, cupronickels, or stainless clad carbon steel. Higher costs of these type materials limit their use to high corrosion areas.

\subsubsection{Brine flow areas}

Brine flow areas of evaporator vessels are generally made of carbon steel, although in some. evaporators it has been found necessary to line the areas below the demisters of the hottest stages [at temperatures greater than $\left.100^{\circ} \mathrm{C}\left(212^{\circ} \mathrm{F}\right)\right]$ with stainless steel primarily to avoid stage corrosion and also the accumulation of iron oxide corrosion products in the recirculating brine streams. Iron oxide quickly fouls the heat transfer tubing and reduces heat transfer performance.

Regions of high turbulence such as the brine splash plates and brine orifices are also normally made of stainless steel.

\subsubsection{Demisters}

Demisters are a knitted wire mesh, typically Monel or stainless steel, although they can be fabricated from a wide variety of metal wires and plastıc tılaments. Uemister retainers are of stailnless steel. Stages where gases are evolved, such as the first or last stage, have experienced de-zincification of Monel demisters.

\subsubsection{Product water troughs}

Product water troughs in MSF plants are subject to corrosive attack on the product side from unpacified distilled water and from below by flashing brine. Noncondensable gases may also contribute 
to corrosive attack in plants having the vent cooling section of the tube bundles near the product water trough.

Because failure may result in severe loss of production and stage geometry makes product water troughs difficult to repair and almost impossible to replace, proper materials selection is of particular concern in this arca.

Product water trough materials currently in use in MSF plants are not standardized and range from carbon steel with liberal corrosion allowances to type 316 stainless steel lined-carbon steel to solid type 316 stainless steel, or $90 / 10 \mathrm{Cu}-\mathrm{Ni}$. Unprotected carbon steel product troughs have generally experienced excessive corrosion in all types of MSF plants and are no longer recommended. Interstage distillate orifices are also made of stainless steel. High temperature sulfuric acid-dosed plants generally have more corrosion resistant materials than low temperature polyphosphate-dosed plants.

Plant designs generally carry the product water from stage to stage under the tube bundles. A few plants have been operated with special provisions to divert high salinity product water from one or more stages back to the brine stream. This provision allows plant operation to continue within allowable product water purity limitations with only a nominal capacity reduction and helps to mitigate corrosion.

\subsection{Tube Bundles}

\subsubsection{Materials ${ }^{26,27}$}

Many of the desalting plants in operation today are tubed with one of the cupronickels, either 70 $\mathrm{Cu} / 30 \mathrm{Ni}$ or $90 \mathrm{Cu} / 10 \mathrm{Ni}$. These alloys are used predominately in acid-treated plants which operate at $121^{\circ} \mathrm{C}\left(250^{\circ} \mathrm{F}\right)$ brine temperature. For the low-temperat ure polyphosphate plants, the Kuwait Ministry of Electricity and Water specified Al-brass tubes for the heat recovery section and $70 / 30 \mathrm{Cu} / \mathrm{Ni}$ alloy for the heat rejection. ${ }^{15}$ In contrast, the Hong Kong plant employs Al-brass tubing and Naval brass tubesheets throughout the plant. ${ }^{13}$ The $90 / 10$ alloy is often specified for the heat rejection sections and brine heaters in $121^{\circ} \mathrm{C}\left(250^{\circ} \mathrm{F}\right)$ plants, since these are the more severe service environments (the high temperature in the brine heater and untreated seawater, often silt laden, in the rejection stages).

Because of its steadily declining price, titanium tubing is being specified more frequently for the heat rejection stages. Due to the high failure rate of the copper alloy heat rejection tubing in the Key West, Florida plant, caused by the presence of hydrogen sulfide, it was replaced by titanium. Three 3790 $\mathrm{m}^{3} /$ day ( $1 \mathrm{Mgd}$ ) plants in the Virgin Islands (one at Hess Oil and two at Martin Marietta) are tubed entirely with titanium.

Tubesheets have been fabricated of steel, lined with cupronickels, Naval brass or titanium (when titanium tubes are used). Steel waterboxes have been lined with cupronickels, Monel, stainless steel, or bare carbon steel has been used with sacrificial anodes. Some plants have used reinforced polyester waterboxes for service at the lower temperatures. Several have employed steel waterboxes for service at the lower temperatures. Others have employed steel waterboxes covered by protective coating both with and without sacrificial anodes, but only with limited success. In general, the premium materials have displayed superior performance, since this is a comparatively harsh environment especially at higher temperature involving both turbulence and abrasion.

Air baffles that form the vent region for the removal of noncondensable gas are made of stainless steel or plastics because of possible high concentrations of $\mathrm{CO}_{2}$ and oxygen.

Both ceramic and cupronickel spray distribution nozzles have been used in VTE plants, with the latter giving superior pẹformance. 


\subsubsection{Tubesheets and waterboxes}

Tubesheets for current plants vary in materials of construction, depending on the type of heat transfer tubing material used. Typical combinations are:

\begin{tabular}{ll}
\hline Tube material & Tubesheet material \\
\hline Aluminum brass & Naval brass \\
Cupronickel & Naval brass, Cu/Ni or \\
Cu/Ni-clad steel \\
Titanium & Al-bronze or Ti-clad steel \\
\hline
\end{tabular}

Interstage tubesheets for long-tube plants and tube supports within stages are generally of less corrosion resistant materials than tubesheets at the ends of the tubes. Muntz metal, and Naval brass are frequently used with success. Carbon-steel tube supports have also been used, with corrosion presenting problems at times, particularly in areas with high noncondensable gas concentrations.

Waterboxes ate generally of carbon steel constuction protected by one of scveral linerscupronickel or other corrosion resistant metals, epoxy, coal tar-or, in some plants, by sacrificial anodes without, or in conjunction with, organic protective coatings. Unprotected carbon steel has been found to be unsatisfactory.

The hydraulic design of waterboxes is very important in VTE and cross-tube MSF plants to ensure proper distribution of water to the tube inlets. Plant purchasers frequently require hydraulic model tests for cross-tube waterboxes of new design. Flow distribution is less of a concern in long-tube plants, where the higher pressure drop along the total tube length forces the distribution to occur more readily. The performance of ball cleaning systems to remove soft scales and sludge from tubes in MSF or MEMS plants requires efficient waterbox design to ensure equal distribution of the balls over the tubesheet face.

Waterboxes are generally provided with vents and drains, a manhole, and local instruments to measure pressure drop and tem perature rise. Problems have occurred on otherwise goud waterbuxes where carbon steel accessories have been used.

Tubes are rolled tightly against the end tubesheets by pneumatic expansion tools. Care must be taken to avoid rolling too little, to preclude leaks at the joint, or too much, to prevent excess thinning of the tube wall within or beyond the inner face of the tube sheet. Titanium tubes are sometimes welded to titanium clad or solid titanium tubesheets. This is a delicate procedure and must be done in the presence of an inert atmosphere. Inlet ends of tubes are sometimes projected a short distance beyond the tubesheet and belled to reduce inlet hydraulic pressure drops.

Tubes may be smooth-walled (all plants) or fluted (VTE), spiraled (MSF, MEMS, MED) or otherwise configured to enhance heat transfer performance.

\subsubsection{Access and replacement}

Tube leaks and failures are inevitable over the life of a plant. Waterbox manholes are generally provided in large plants to allow inspection of tubes for leaks without removing the waterboxes. Leaks can be found by slightly pressurizing the evaporator shell and noting the tubes where air escapes. When less than about $10 \%$ of the tubes in a bundle have leaks, any leaking tubes are taken out of service by inserting plugs in each end. At some point the loss of product water purity and plant performance 
dictates that the tubes be replaced. This is a major operation and is usually carried out during a scheduled maintenance outage. Removing tubes can be difficult if misalignment of tubesheets has occurred or carbon steel tube-support plates have corroded, or tube removal allowances have not been provided (or maintained) for the full tube length at one end of the tube. Likewise, installing new tubes in an existing evaporator is usually more difficult than in a new plant.

\subsubsection{Cleaning}

As noted earlier, when polyphosphate chemicals are used for alkaline scale control, it is necessary to periodically clean the heat transfer tubing. It is difficult to predict the frequency of cleaning, for it is highly variable from plant to plant and even within one plant. Frequency of cleaning varies with type of proprietary polyphosphate preparation, tube side velocity, seawater feed, whether circulation is oncethrough or recycle, and the maximum temperature. The time between cleanings can range from one week to several months, a typical cleaning frequency being every two to four weeks. The need for cleaning is indicated by one or all of the following:

a. a high total pressure drop across the brine heater and heat recovery section;

b. higher than normal steam or condensate temperatures at the brine heater;

c. lower than normal recycle brine temperature out of the heat recovery stages and increased steam consumption at the brine heater.

The common method of cleaning polyphosphate-dosed MSF plants is by on-line cleaning by injecting sufficient inhibited hydrochloric or sulfuric acid into the seawater makeup stream to maintain the brine recycle $\mathrm{pH}$ at 4.5 until alkaline scale is dissolved and the above parameters are within acceptable values. Cleaning time may range from 5 to 48 hours. Production of acceptable quality water is maintained during the cleaning period.

An alternate method of on-line cleaning smooth-walled tubes is the use of a fully automated system which utilizes sponge rubber balls.* By this method a continuous cleaning of the inner surface of the tubes of the heat recovery cycle takes place. The balls are slightly larger than the inside diameter of the tubes and are forced randomly through the tubes by the hydraulic pressure of the flowing brine. As the balls travel through the tubes, they wipe and dislodge the soft scale from the tube walls. The number of balls used is about 10 to $15 \%$ of the number of of tubes. The balls are caught in a strainer at the outlet of the brine heater and recirculated after backwashing. While the system can be fully automated, the number and size of the circulating balls must be checked once a week and replaced manually as needed. The balls are rated for service up to $105^{\circ} \mathrm{C}\left(221^{\circ} \mathrm{F}\right)$ and will not effectively clean tubing smaller than $0.02 \mathrm{~m} \mathrm{(3/4} \mathrm{in.)} \mathrm{in} \mathrm{diameter.} \mathrm{Balls} \mathrm{with} \mathrm{abrasive} \mathrm{strip} \mathrm{on} \mathrm{them} \mathrm{may} \mathrm{be} \mathrm{used} \mathrm{for} \mathrm{harder} \mathrm{scales.}$

Calcium sulfate scales, if they occur, are much more difficult to remove. However, it may be done chemically, by use of metallic brushes, or by hydrolances using cold freshwater or seawater at $6,900 \mathrm{kPa}$. (gauge) (10,000 psig) or above. This latter method must be done with highly-trained operators because of the hazards involved.

\subsection{Brine Recirculation Pumps and Drivers}

In 1966 the U.S. Bureau of Reclamation made an in-depth evaluation of large pumping units for desalting plants. ${ }^{28} \mathrm{~W}$ ith the exception of the price information, the conclusions presented in this report

*In Europe this is known as the Taprogee system and in the United States as the Amertap system. 
are considered to still be valid today. As a part of this study the eight most prominent U.S. pump manufacturers were asked to submit recommendations on pump types and matcrials selections for feedwater, brine, and distillate pumps. Contracts were let with three of these manufacturers to make detailed studies related primarily to materials selections for the various pump service conditions. They concluded that the optimum brine recirculation pump, because it required deep setting, was the vertical-shaft type. Although they are premium materials, type $316 \mathrm{~L}$ (wrought) and DF-8M (cast) stainless steels were selected as the optimum materials for long service life for components in contact with hot brine.** There was also agreement that highest efficiencies would be at specific speeds between 2500 and $3000 \mathrm{rpm}$. All manufacturers recommended synchronous electric motor drivers (prime movers), 13.8-kV, 3-phase, 60-cycles, although it is not known if they were asked to consider steam turbine drivers.

As a result of 20 years of experience with polyphosphate-dosed plants, the Ministry of Electricity and Water of the Government of Kuwait has also recommended type $316 \mathrm{~L}$ stainless steel for casings, shafts, impellers, and all other wetted pump internals, lor bine recirculations. ${ }^{\text {.' }}$

In the Hong Kong plants, which operate at $121^{\circ} \mathrm{C}\left(250^{\circ} \mathrm{F}\right)$ with acid-treated feed water, all brine pumps have type 316 stainless steel impeller's and Ni-resist 2 cosinge: ${ }^{13} \mathrm{Ni}$-resist was also listed in the Bureau of Reclamation report as a material well suited for hot brine service. However, it is suitable only for castings, and the U.S. pump manufacturers were relunctant at that time to specify Ni-resist castings for very large pump casings. In addition, field experience has shown Ni-resist pumps have far higher maintenance and failure rates. Successful operating experience with a brine rccirculation pump $\pm 17,500 \mathrm{~m}^{3} / \mathrm{h}$ at $70 \mathrm{~m}$ total head $\left.(77,000 \mathrm{gpm}, 229 \mathrm{ft})\right]$ to serve a $64,345 \mathrm{~m}^{3} /$ day $(17-\mathrm{Mgd})$ plant was obtained during operation of the MSF Module at Chula Vista, California.

\subsection{Brine IIeaters}

Brine-side materials of construction for brine heaters have varled from plant lu plant in recent years. In general, the tubes are cupronickel, and tubcshcct and waterbox material qualities are equal to or greater than their counterparts in the most severe-duly stages of the evaporator plant. Shell-side materials are generally carbon steel. Corrosion and erosion of the inlet/ourlet waterbux divider have caused problems on some two-pass brine heater designs, particularly if unlined carbon stccl has been used.

\subsection{Decarbonators}

Sulfuric acid for scale control adds approximately 100 to $120 \mathrm{ppm}$ of carbon dioxide to the seawater as a result of bicarbonate decomposition. Removal can be accomplishod prior to or simultaneously with removal of air in a vacuum deaerator. Separate decarbonation, with $\mathrm{CO}_{2}$ release to the armnsphere, is preferable and common for large plants to reduce the sizes of the deaerator and its vacuum system. These benefits must be weighted against the added capital costs of the decarbonator, additional piping and possibly another pump, and the operating costs of the pump and an air blower.

Decarbonation occurs when the acidified makeup of seawater is brought in contact with ambicnt air. Current practice is generally to strip $\mathrm{CO}_{2}$ to about $3 \mathrm{ppm}$ in a packed tower, with air blown upward countercurrent to downward falling makeup. Because high temperatures and vacuum conditions are

\footnotetext{
**It should be noted that these alloys are subject to pitting in stagnant brine. Consequently, during shutdown they must be thoroughly flushed with fresh water or distillate.
} 
not a consideration, towers typically are constructed of low cost, seawater resistant materials, such as wood, or coated steel, with wood or plastic flow distributors inside. Concrete collection sumps are situated below the decarbonator.

\subsection{Deaerators}

The Office of Saline Water sponsored a number of studies and field test programs directed to the design and performance of available commercial deaerators and advanced concept deaerators. ${ }^{29-32}$ Deaerators physically remove dissolved atmospheric gases [nitrogen $(\sim 20 \mathrm{ppm})$, oxygen $(\sim 8 \mathrm{ppm})$, $\mathrm{CO} 2(\sim 3 \mathrm{ppm})]$ from seawater feed before it enters the desalting plant. This is done primarily to minimize corrosion of heat transfer surfaces and structural materials, and secondly to prevent gas blanketing of condenser surfaces, with resulting loss in heat transfer. In desalting plants where acid-dosed feed is used, an additional 100 to $120 \mathrm{ppm}$ of carbon dioxide must be removed, either by the deaerator or by a decarbonator, upstream of the deaerator. Target levels of residual gases following deaeration-decarbonation (with subsequent treatment using sodium sulfite to scavenge oxygen) are 50 $\mathrm{ppb}$ (parts/ billion) $\mathrm{O}_{2}$ and $2 \mathrm{ppm} \mathrm{CO}$. Vacuum deaerators remove dissolved gases by transferring them into a low-pressure steam phase and venting the resulting steam-gas mixture at a rate sufficient to keep the gas concentration at acceptably low concentrations.

Based on the work reported in Ref. 32, a packed column using stripping steam and spray feed can be used to lower the oxygen concentration to $50 \mathrm{ppb}$, even when the seawater is subcooled.

\subsection{Piping and Valves ${ }^{33,34}$}

Because of their low first cost and ready availability, carbon steels have been used extensively for piping in desalting plants. Generally these steels have performed satisfactorily in deaerated brine and condensate at temperatures up to $\sim 93^{\circ} \mathrm{C}\left(200^{\circ} \mathrm{F}\right)$. At higher temperatures, generalized corrosion has increased and localized pitting attack has occurred. Major problem areas have been associated with directional changes, high velocity, impingement and in heat affected zones where weldments were made. Accelerated attack has also been noted during periods when plants have been operated with inadequate deacration and/or venting, or when inleakage of air into the plant has occurred.

In general, steel piping has performed better in polyphosphate treated plants than in acid treated plants due to the lower temperature of operation and a more favorable $\mathrm{pH}$ range.

Steel pipe lined with several types of cement mortar has also performed well at low temperatures when the linings wcrc properly installed, except in areas of very high turbulence (elbows) or where they suffered mechanical damage.

Use of plastic pipe (PVC or FRP) has been generally limited to temperatures below $93^{\circ} \mathrm{C}\left(200^{\circ} \mathrm{F}\right)$ and has displayed satisfactory service except in areas where vibration caused stress cracking.

Where proper selections of materials have been made, valves have displayed generally satisfactory service. Failures have been attributed to poor castings and improper materials selection, especially when they have been used in throttling service or in brine or vent service. One specific problem area was the failure of lined (Hypalon, Hycar linings) gate and butterfly valves at the Office of Saline Water, Freeport, Texas, and San Diego, California, Test Facilities.

\subsection{Vacuum Systems}

Vacuum systcms for commercial desalting plants are provided to remove dissolved noncondensable gases liberated from the feed water stream and to evacuate air inleakage from the vacuum stages of the 
evaporator vessel. Although all noncondensable gases are of concern because their presence in the evaporator tube bundles impedes efficient water vapor condensation, $\mathrm{CO}_{2}$ and oxygen are of particular concern because of their contributions to brine chemistry and plant corrosion.

The nearly universal choice for plant vacuum system design is high pressure steam driven multistage ejectors coupled with condensers. Mechanical vacuum systems have often been considered, but seldom used.

Within the ejector/condenser selection, however, there are many alternative system configurations in use, which vary according to the type of process employed (acid versus polyphosphate) and the preferences of plant designers and owners. Ejectors are most commonly arranged in two or three stages, each with an installed spare, separated by water-cooled intercondensers to reduce the water vapor inlet flow to the next stage ejector. A separate startup (hogging) ejector is provided on large plants to draw initial plant vacuum wițin one hour.

Condensers are either the barometric type or shell and tube type. In addition to intercondensers, a first stage precondenser and a final stagc aftercondenser are commonly provided. Barometric condensers are generally cooled by seawater, with the eftluent discharged to sea by a pump ui vacuum drag, or returned to a low pressure evaporator stage for further flashing as allowed by the drain temperature and removal by the blowdown pump. Product water has also been used to cool barometric intercondensers with the cooling water and condensed vapors being reclaimed as additional product water.

Typical materials for vacuum systems are:

Ejectors:

Nozzles and diffusers: $\quad$ Stainless steel

Steam chests: C'ast iron

Barometric condensers:

Shell:

$\Gamma R \Gamma^{*}$ or coated steel

Nozzle:

Stainless steel

Shell and lube condensers:

Shell:

Tubes:

$$
\begin{aligned}
& \text { Stainless steel } \\
& \text { Titanium, stainless steel, } \\
& \quad \text { or } \mathrm{Cu} / \mathrm{Ni}: 70 / 30
\end{aligned}
$$

Piping:

Steam:

Carbon steel

Vapor and liquid: $\quad$ FRP* or stainless steel

Problems associatcd with plant vacuum systenins are usually corrosion related and a result of improper materials selections. Changes in the types of feedwater treatment chemical used have also overloaded the vacuum systems in some plants.

\subsection{Instrumentation and Controls}

The primary measurement and control objectives of current commercial MSF plants arc (1) to keep the plant on-line, and (2) to prevent excessive corrosion or scaling. Control of plant parameters in order to maximize the product water output or performance ratio is typicaliy of secondary concern.

* Fiber reinforced plastic. 
When it is done, it is accomplished by manual adjustment of the condenser bundle vent valves and, when possible, interstage orifice settings-all by trial and error.

Measurement technology for parameters such as flow, temperature, water level, and plant chemistry has been developed to the point where all of these can be monitored accurately and reliably; however, in practice, many obstacles preclude satisfact ory results. Flow measurement accuracy for brine or product water in a pipe, for example, is often degraded by flashing across a metering orifice or by insufficient metering-run pipe lengths before a measuring station (especially in the case of large diameter pipes). While local temperatures can be measured very accurately, in large-diameter pipes and especially in brine and product trays, the nonuniform temperature and velocity profiles make the determinination of a good, integrated average difficult, if not impractical. Hence, parameters such as individual stage performance and efficiency are difficult to determine (and hence control). Liquid levels in the brine and product trays are also very important to control because of the sensitivity of stage efficiency to level. While site glass indicators a re satisfact ory for field ohservations, differential pressure transmitters used for remote level monitoring are usually unreliable because of difficulties in keeping the sensing lines full (or free) of liquid.

Some plant chemistry instruments, such as $\mathrm{pH}$ monitors and controllers, are relatively delicate and sensitive, and have typically had poor operating histories in the field. Such problems are usually due to improper installation and/or inadequate maintenance.

The major plant control systems in the MSF plant center around maintaining proper temperatures and flows in the flashing brine stream. Recycle brine flow control normally has the multiple tasks of preventing flashing in the brine heater tubes and keeping the brine levels in the hot stages within reasonable limits. Brine heater temperature control maintains either the brine heater outlet temperature or the first stage flashing brine temperature constant by varying the stea m flow. Seawater makeup flow is either controlled manually or by a brine concentration control system (i.e., blowndown/makeup ratio control). Also, the blowdown flow is adjusted to keep a constant sump (or last stage) level, as are the product water and brine heater condensate flows.

The use of sophisticated data loggers, on-line computers, and closed-loop computer control on MSF plants has heen studied, but is probably not economical on today's small commercial plants. It is expected, however, that such techniques would be feasible, and perhaps desirable, for plants approaching $189,250 \mathrm{~m}^{3} / \mathrm{d}$ (50 Mgd) of product water output.

\subsection{Seawater Intakes and Outfalls}

The principal objective in successful sea water intakes and out falls is the elimination of extraneous suspended matter, both organic and inorganic, from the feedwater, and dispersion of the ret urned hot brine so as to protect the environment in the vicinity of the outfalls and preclude recirculation to the intake. To accomplish these objectives, several systems have been used in existing desalting plants, wells drilled into coral, jetties to provide protected water basins, and piping, which is placed on or below the ocean bottom to an intake structure. Materials which have been utilized for pipe in a salt water environment are steel, both bare or lined, concrete, and fiberglass. Piping material choices are affected by inherent strength, tesistance to corrosion, and ability to withstand physical damage from outside forces. Large piping is usually other than steel; concrete is recommended for over $914 \mathrm{~mm}$ (36-in.) diam. Exterior protection has required bottom trenching and rock or concrete cover, especially in the surf-line.

Intake structurcs should be located where suspended particles of silt or sand are at a minimum, that is, outside surf liness, away from strong tidal-flows or ocean currents, etc. Present intakes often 
incorporate fish caps which consist of horizontal baffles to force initial intake flow from the surrounding water mass to be in a horizontal direction.

Intake piping at times conducts the feedwater to a stilling basin, from which it passes through trash racks and traveling screens to eliminate most debris and suspended particles.

Trash racks and screens are constructed either of corrosion resistant materials or utilize special coatings such as epoxy-based paints. Some units are designed to be easily replaceable using economical "throw-away" type materials.

This system of underwater remote intakes, stilling basins, trash racks, and traveling screens is used successfully on many existing desalting plants; but screen maintenance is high because of the corrosive effect of seawater and marine growth.

An alternate intake utilizing wells drilled into sand or coral has furnished feedwater for many plants. The Key West Plant developed problems with hydrogen sulfide from coral residues, which caused extensive corrosion and eventual replacement of extensive portinns of the evaporator.

Outfalls consist of channels or piping laid along the ocean bottom with numerous ports to disperse the hot brine in such a manner that natural mixing with adjacent seawater will minimize the detrimental effects on the environment. Multipipe designs are utilized for maximım dispersing, and designs must. provide for the most uniform outflows. Outfalls are located so that no short circuiting will occur with the seawater intakes.

\subsection{Other Pumps and Drivers (Ref. 28, 29)}

In addition to the brine recirculation pumps (Sect. 4.8), the other major pumps in a plant are the seawater feed, brine blowdown, and distillate (product water) pumps. Seawater feed pumps generally lake their suction at at mospheric pressure and have head requirements in the order of 15 to $46 \mathrm{~m}$ ( 50 to $150 \mathrm{ft}$ ), depending on the process employed, terrain, etc. The Bureau of Reclamation specified shafts of type 316 stainless steel, or, for very large units, type 316 stainless stecl-clad shafts $[0.006 \mathrm{~m}(1 / 4 \mathrm{in}$.) minimum thickness]. Type 316 stainless steel casings and cast type 316 stainless steel (CF-8M) for the impellers were the choices for large pumps. Synchronous motors, 13.8-kV, 3-phasc, 60-cycles were rerommended as drivors.

Squirrel cage motors at 4160-V, 3-phase, 60-cycles were recommended as drivers for the brine recirculation pumps for plants. The pumping units were vertical column (can) centrifugal dry-pit or vertical column wet-pit (one manufacturer's recommendations only) pumps. These pumps take suction at $\sim 10.3 \mathrm{kPa}(\sim 1.5 \mathrm{psia})$, as do the brine recirculation and distillate pumps. Material choice was CF-8M stainless steel for impellers and casings.

Distillate (product) pumps were specified as dry- (or wet-) pit pumps with squirrel cage motors operated on 4160-V, 60-cycle, 3-phase current. Casings of 3\% nickel-cast iron with bronze trim were connsidcred adeglate fur his service.

Reports from current large MSF plant installations indicate that premium materials are preferred to minimize corrosion problems for critical pumping services. The Kuwait ${ }^{28}$ specifications for the blowdown pumps are for vertical, diagonal flow types with cast type 316 stainless steel impellers and casings a $ı$ lype $310 \mathrm{~L}$ stainless steel shatts. Distillate pumps a re specified as the vertical flow type with cast bronze casings (PBC2S), type 316 L stainless steel shafts and cast type 316 stainless steel impellers. The Hong Kong ${ }^{31}$ specifications call for type 316 stainless steel impellers and $\mathrm{Ni}$-resist 2 casings for all major pumps. Low alloy steel and nonferrous materials are not allowed in their pumping units. 


\subsection{Chemical Dosing Systems}

The feedwater to distillation plants using either polyphosphate or acid feed treatment is chlorinated, either intermittently (shock chlorination) or continuously, depending on the quality of the seawater. Chlorine may be purchased and shipped to the site in cylinders, tank cars, or barges, depending on the quantity needed, or it may be generated in situ (as sodium hypochlorite) via elect rolysis of sea water. In sit u generation of $\mathrm{NaOCl}$ (sodium chlorite) is carried out using a controlled flow of clean seawater into an electrolytic cell which contains an anode and cathode that are charged with harmless, low voltage direct current rectified from an ac power source. Chlorine (or $\mathrm{NaOCl}$ ) is normally injected at or near the seawater intake. There are numerous manufacturers of completely automated chlorine metering equipment and residual chlorine analyzers.

Polyphosphate chemicals (usually containing an antifoaming agent) are shipped to the site as dry powder. The powder is weighed and mixed with fresh water to provide a concentrated solution that is injected into the feedwater stream by a metering pump. The metering pump is preset to automatically deliver the required dosage of chemical on a continuous basis. The polyphosphate solution is usually prepared daily. There are varieties of metering pumps available for this service.

In plants using acid treatment for scale control, bulk $98 \%$ sulfuric acid is stored in mild steel tanks which are blanketed with a dry gas or equipped with desiccant type air dryers to prevent ingress of moisture. Mild stcel piping and alloy 20 valves and pumps are commonly used for handling the acid. The initial acidification involves adding $\mathrm{H}_{2} \mathrm{SO}_{4}$ to the sea water, insuring dispersion of the acid in the seawater, release of the $\mathrm{HCO}_{3}$-by the acid, and measurement of the $\mathrm{pH}$ for control, all before the mixture is sprayed into the decarbonator. In acid-dosed plants the most difficult problem is proper design of the mixing system to insure proper mixing and reaction time for the viscous $66^{\circ} \mathrm{Baume}_{2} \mathrm{SO}_{4}$ in the brine before its $\mathrm{pH}$ is measured.

Caustic neutralization, if used to adjust the brine $\mathrm{pH}$ after decarbonation and deaeration, involves a $10 \%$ sodium hydroxide solution. This solution is less viscous than concentrated $\mathrm{H}_{2} \mathrm{SO}_{4}$ and thus offers fewer mixing problems.

Polyphosphate-dosed plants also require acid feed pumps to inject cleaning acid into the plant for descaling. This is an intermittent service with acid injection for periods typically from 5 to $48 \mathrm{~h}$. Thirty-seven percent acid is pumped into the makeup stream with a positive displacement type pump.

The major area of concern related to chemical dosing systems has been inadequate mixing and $\mathrm{pH}$ control in acid-dosed plants. This problem has been the subject of at least two investigations, ${ }^{32}$ and methods have been developed and successfully demonstrated using several different schemes of mixing.

\subsection{Maintenance and Repair Facilities}

Physical facilities to support plant maintenance and repair vary throughout the world from next-to-nothing to sophisticated machine shops dedicated or available to the plant. Factors influencing owners' decisinns in this area include:

- type of facility-water only, process plant, factory, etc.;

- remuleness of the sitc;

- plant size;

- availability of competent local contractors;

- budget considerations;

- owner sophistication and/or past experience;

- end usc of the product water. 
As a minimum most plants have, either on-site or available locally

- an adequate supply of operating consumables;

- a supply of small spare parts including pipe fittings, valves, gaskets, gauge glasses, pump seals, etc.;

- tube plugs, and tube rolling and pulling equipment;

- a good set of industrial hand tools;

- metal cutting, welding, and machining equipment;

- lifting equipment for water boxes and pumps.

The trend in recent years has been for more sophisticated maintenance facilities. For the two $14,000-\mathrm{m}^{3} / \mathrm{d}(3.67-\mathrm{Mgd})$ plants for the Jidda, S.A. Naval Base, for example, the specifications call for extensive support facilities, including a two-story building with space for a central control room for all plant systems, office space for operating and administrative personnel, room for spare parts storage, a machine and equipment repair shop, a chemistry control laboratory, meeting rooms, and sanitary facilities. The control room is to be glassed-in on two sides to provide a foll view of the boiler plant and desalting plant areas. The machine shop is to be equipped with lathes, a milling machine, metal cutting and welding equipment, a monorail hoist for equipment handling, and smaller shop tools to facilitate nearly complete onsite maintenance and repair capability. The chemical laboratory is to be fully equipped for rapid analysis of control variables and will have room provided for the installation of additional analytical equipment that may be desired for investigation of any unanticipated corrosion or scale formation problems.

\subsection{Staffing Requirements}

Following is a first approximation of some of the specific considerations and requirements which will be necessary for personnel planning and training.

The administrative staff may vary with operating philosophy, however, it is not likely to change significantly because of choice of plant design.

The size of the plant maintenance staff may vary depending on the extent to which major repairs and overhaul are to be performed with onsite labor. Although the requirements for maintenance labor can be expected to vary with the number of equipment items requiring frequent servicing, such as pumps and instruments (and with the selection of materials and design details for tube bundles and evaporator shells), sufficient experience for any quantitative correlation between labor requirements and specific design, has, until recently, been overshadowed by the problems associated with corrosion and poor materials selections.

The 15 conceptual designs which were prepared for the Office of Saline Water each presented staffing requirements for a $190,000-\mathrm{m}^{3} / \mathrm{d}(50-\mathrm{Mgd})$ desalting plant. ${ }^{39}$ The average staff for these designs was 30 people, although a single $190,000-\mathrm{m}^{3} / \mathrm{d}(50-\mathrm{Mgd})$ plant has never been operated. The agreement between the various designers was very close in all but two designs (18 and 47 , respectively). 
For a single $250,000-\mathrm{m}^{3} / \mathrm{d}(66-\mathrm{Mgd})$ desalting plant, the minimum staffing required to maintain a high stream factor and long-term plant integrity would be approximately as follows:

\begin{tabular}{lc}
\multicolumn{1}{c}{ Operating personnel position } & Number of personnel \\
Plant superintendent & 1 \\
Assistant plant superintendent & 1 \\
Plant engineer & 1 \\
Assistant plant engineer & 1 \\
Senior process engineer & 4 \\
Shift supervisor & 4 \\
Control operators & 1 \\
Relief operators & 4 \\
Auxiliary operators & 1 \\
Clerk stcno & 1 \\
Bookkeeper & 2 \\
Storekeeper & 2 \\
Janilor-laborer & 4 \\
Guards & - \\
Total plant operating personnel & 28 \\
Maintenance personnel position & Number of personnel \\
Maintenance supervisor & 1 \\
Assistant maintenance supervisor & 1 \\
Electrical maintenance & 2 \\
Mechanical maintenance & 3 \\
Instrument technician & 3 \\
Laborers & 42 \\
$\quad$ Total plant maintenance personnel & -14 \\
TOTAl. Pl.ANT PERSONNEL. & \\
&
\end{tabular}

The above staffing is based on the assumptions that the plant is well instrumented, that contract maintenance will not be provided, and that inventories of spare parts are available. It is estimated that multiple $250,000-\mathrm{m}^{3} / \mathrm{d}$ plants at the same site would require additional staffing of approximately 25 personnel per additional plant. It is possible that some personnel (e.g., the plant chemist) might be shared between the nuclear facility and the desalination plant. This will depend on management philosophy and plant siting.

\subsection{Distillation Plant Costs}

The average capital cost of distillation desalting plants, as a function of plant size, is shown in Fig. 24. These costs, given in 3 rd quarter 1979 dollars, exclude certain site specific costs such as the purchase of land or the costs of product water storage and distribution systems. Costs are included for site development and other civil work such as the construction of intake and outfall systems, assuming a typical United States costal site which would not require excessive development work. These costs were developed using the following financial parameters: $9.5 \%$ interest on capital during the construction period; working capital, $5 \%$ of the total direct capital cost; a contingency and architect-engineering fce equal to $16 \%$ of the direct and indirect capital rosts. A verage const ruction periods would range from 18 months for a plant of $3785 \mathrm{~m}^{3} / \mathrm{d}$ ( $1 \mathrm{Mgd}$ ) capacity to 42 months for the $378,500 \mathrm{mi}^{3} / \mathrm{d}(100 \mathrm{Mgd})$ plant.

Fuel costs would comprise slightly over half the annual operating costs, using steam extracted from a nuclear driven turbine. It has been estimated that these costs could be reduced by as much as 20 to $25 \%$ if large back pressure turbines were available. ${ }^{36}$ Water costs (first quarter 1980) shown as a function of distillation plant size are presented in Fig. 25. 


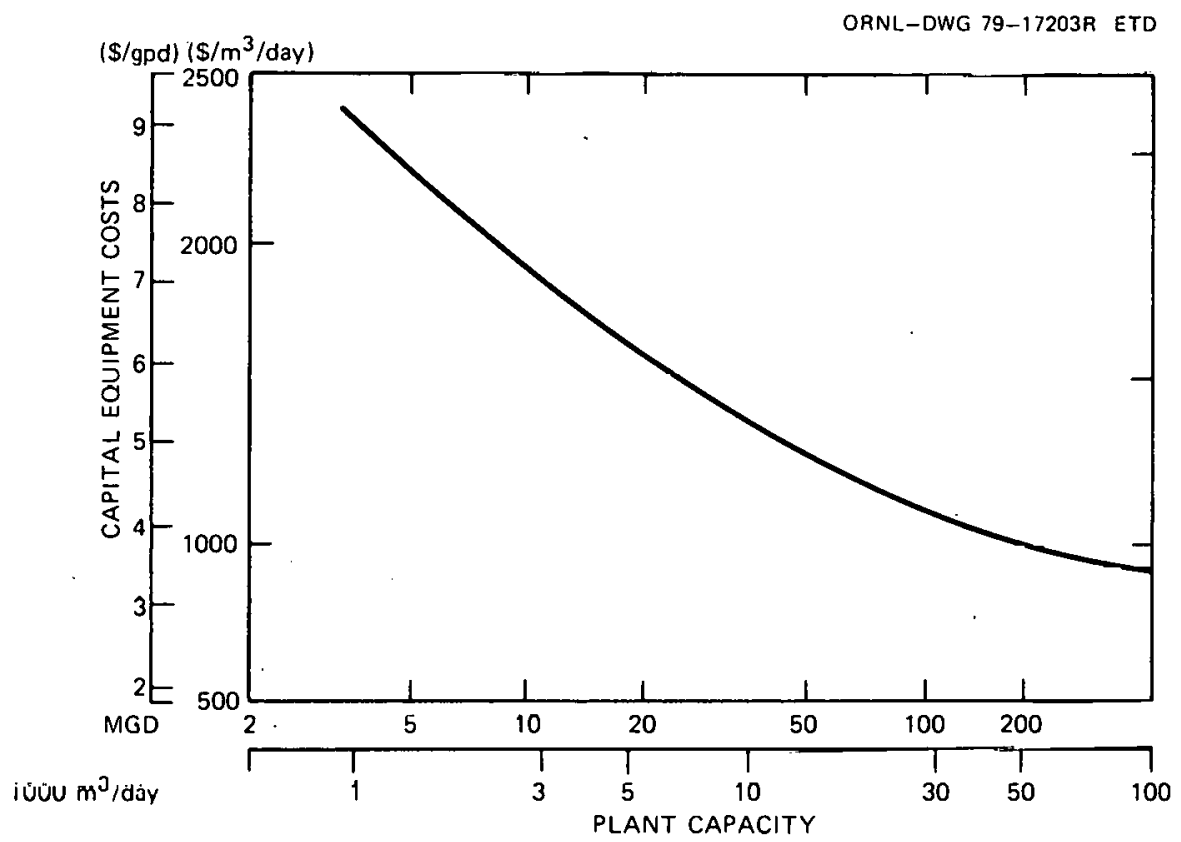

Fig. 24. Average capital cost of distillation desalting plants as a function of plant size.

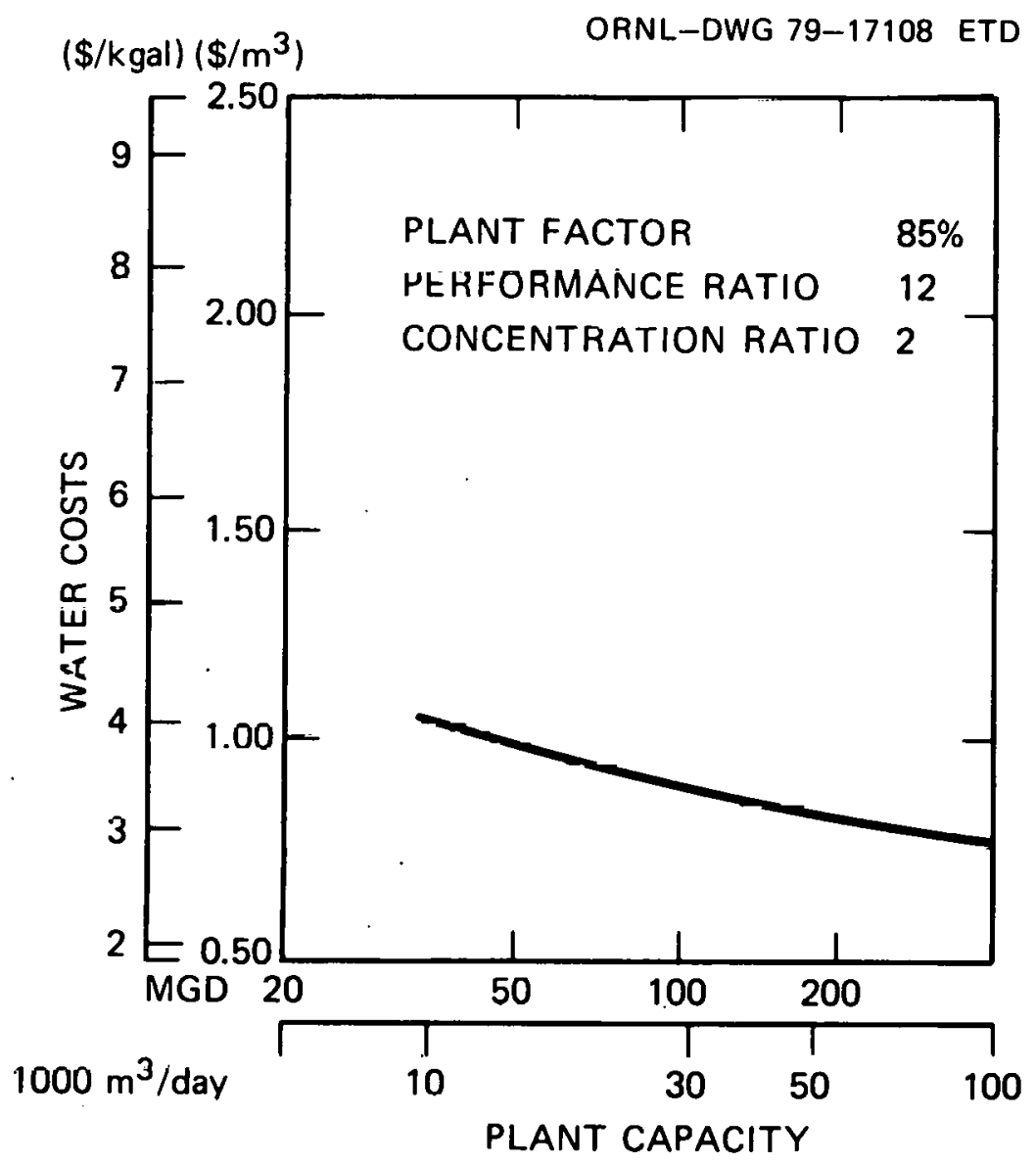

Fig. 25. Water cost as a function of plant size (1st quarter 1980 dollars). 


\section{COUPLING AND CONTROL REQUIREMENTS FOR LARGE DUAL-PURPOSE PLANTS*}

With large dual-purpose distillation plants utilizing back-pressure turbines, a large portion of the steam that flows through the turbine-generator plant is also used in the desalting plant. ${ }^{37-39}$ This results in a very close coupling between electricity production and water production. The production of electricity depends on the operability of the evaporat or since the evaporat or plant provides the heat sink for the power plant. On the other hand, the production of water depends on the production of elect ricity since the energy source for the evaporators is exhaust stea $\mathrm{m}$ from the back-pressure turbines (BPT). Yet the nature of the two products is vastly different. Electrical production and consumption must be coincident. Even large efficient power plants that would normally be considered base load units must follow load changes to some extent; thus, a power plant must be designed with a certain amount of capability for off-design performance. Also, the production of electricity makes minute-to-minute reliability an important design criterion. In contrast with the electricity production requirements, water is storable and therefore need not be produced as it is consumed. Because water production is a capital intensive process, economics dictate that desalting plants have a high average value of plant factor. The minute-to-minute reliability factor is not as important as for a power plant. Unlike power plants, however, evaporators have a narrow margin of off-design operating conditions; they are essentially base-load machines.

The challenge in coupling the two processes is to provide a design that will satisfy the diverse operational requirements imposed by power and water production and yet retain the inherent economic advantages of the dual-purpose plant.

Since dual-purpose plants have been built, one might ask why present technology cannot be applied. The answer lics in the differences between present and tuture plants. These differences arc as follows:

1. The amount of water produced relative to the a mount of power produced in most present plants is in the range of 0.075 to $0.38 \mathrm{~m}^{3} / \mathrm{d} \cdot \mathrm{kW}(20$ to $100 \mathrm{gpd} / \mathrm{kW})$. Future large-scale plants are expected to have product ratios of 0.38 to $1.90 \mathrm{~m}^{3} / \mathrm{d} \cdot \mathrm{kW}$ ( 100 to $500 \mathrm{gpd} / \mathrm{kW}$ ). The degree of interdependence of production is determined by the product ratio.

2. The size of present evaporat or installations is a few million gallons per day. Futurc plants will be several times larger and more costly. The difference in size requires a different approach in the design of coupling arrangements and control systems. Present practice is to field modify evaporator plants to achieve satisfactory operation. In a single large-scale plant, downtime for such work could mean a substantial loss in revenue.

+S. I. Rall of the ORNL Instrumentation and Controls Division prepared portions of this section. 
An important factor in the coupling of large dual-purpose plants is the economic choice of turbine exhaust (or extraction) steam temperature. The contribution of heat cost to water cost as a function of steam temperature is shown in Fig. 25. Since the contribution of heat cost to overall water cost diminishes with increasing steam temperature, most of the development effort on dual-purpose nuclear desalting plants has been directed toward plants using high-temperature evaporators. Primarily, the interest in high-temperature evaporators was a carryover from single-purpose evaporator plants where the heat cost was quite high and also independent of maximum evaporator temperature. Under this circumstance it is desirable, from the standpoint of economics, to develop the highest-tcmperature evaporator possible. However, the maximum practical steam temperature is limited by the scaling constituents (calcium and magnesium salts) in seawater, and by the increased cost of materials of construction which are required to withstand the higher operating conditions. While it is possible to pret reat the seawater to remove a portion of the scale-forming salts, common practice has been to limit the maximum brine temperature to $121^{\circ} \mathrm{C}\left(250^{\circ} \mathrm{F}\right)$ and to control the brine concentration to avoid scale formation. With a $121^{\circ} \mathrm{C}\left(350^{\circ} \mathrm{F}\right)$ maximum brine temperature, steam to the brine heater would be $126-129^{\circ} \mathrm{C}\left(259-264^{\circ} \mathrm{F}\right)$.

Depending on the desalting plant design parametcrs and steam condition requirements, there are several options for providing steam from the turbine cycle to the desalting plant. It is possible to use a high back-pressure turbine at a base load condition and use high-temperaturc (and pressure) exhaust steam in the distillation plant. Suitable high back-pressure turbines are not presently manufactured in the United States but they are available in Europe and are currently being used in the U.S.S.R. in district heating applications.

Steam may also be extracted from the crossover between the high- and low-pressure sections of a turbine or from various other combinations from the regenerative feedwater heating circuits.*

In a dual-purpose plant it is not necessarily true that the high-tempcrature plant will yield the most economical water cost. On the contrary, there are some very good reasons why lower-temperature evaporators may be more economical. First, lower cost materials such as aluminum alloy heat transfor surface and concrete shells may be satisfactory for Inw-temperature operation. Sccondly, siguificitully luwer hear costs can he expected from dual-purpose plants at these luwer temperatures. Thirdly, chemical feed treatment costs are substantially reduced at low-tempcrature conditions. Finally, power plant turbines with exhaust conditions up to about $82^{\circ} \mathrm{C}\left(180^{\circ} \mathrm{F}\right)$ are being developed for use with dry cooling towers but their application has not as yet become widespread. These same turbines would be suitable for use with low-temperature evaporators at an ocean site.

These combined factors are currently being investigated in the joint U.S./Israel program which is described in more detail in the Appendix

The effect of extraction steam temperatures on steam cost is illustrated in Fig. 26. Although these data were calculated for a nuclear heat source, a similar relationship would be obtained for fossil sources. As steam temperature is reduced, the cost of steam is also raduced. On the other hand, the optimum performance ratio also decreases with stea $m$ temperature. The result of this is that evaporator designs, including materials choices, need to be custom tailored for dual-purpose plant applications if the maximum economic advantage is to be derived from the dual-purpose concept. ${ }^{3.39}$

In addition to the steady-state coupling considerations for dual-purposc plants, it is necesary to assure that the dynamics and control characteristics are satisfactory over the entire operating range.

-This is discussed in more detail in the Appendix. 


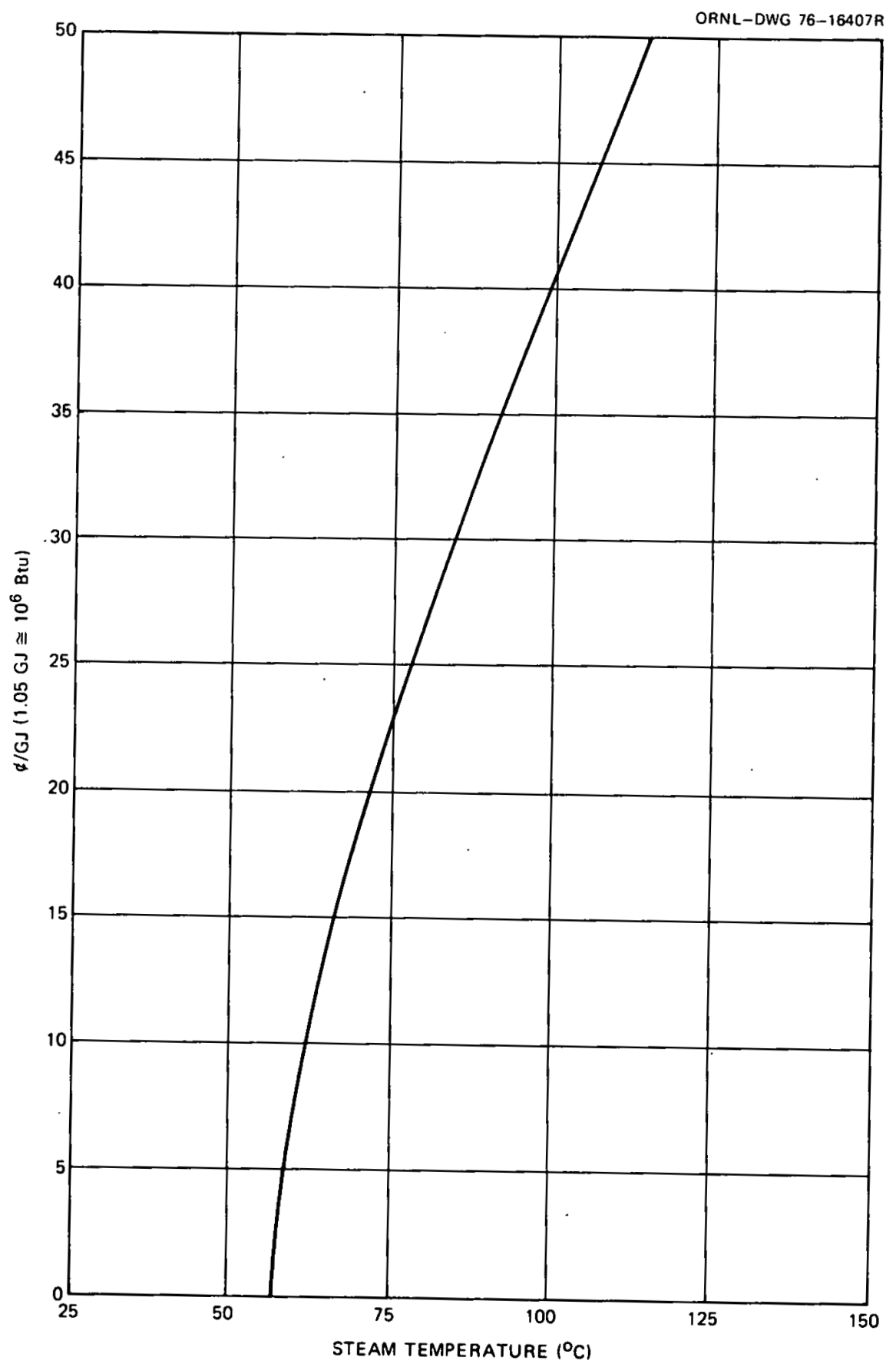

Fig. 26. The effect of extraction steam temperature un the cust of steain. 
The problems of controlling large desalting plants were studied at ORNL both theoretically and experimentally. These studies of the dynamics of multistage flash plants (MSF) and pressurized-water reactor ( $P W R$ ) systems indicate that the overall plant stability characteristics are highly dependent on both the hydraulic design of the MSF plant and the means of coupling of MSF plant to the heat source.

The behavior of such dual-purpose plants was predicted using digital simulators that calculate the response of the evaporator, turbine generator, and reactor to input perturbations. The mathematical models and correlations used in the simulators were, where possible, derived from experimental data. When the models and parameters were not well established, the sensitivity of the predicted plant behavior to variations in the assumed models was determined. This information was then used to guide the experimental work, the objective being to narrow the uncertainty ranges of the critical models to improve the predictions of overall plant dynamic behavior.

Dynamics studies of experimental MSF evaporators included a determination of their behavior from both frequency-response and large-perturbation tests. Other steady-statf correlations were derived by using parameter trend tests, with computer-assisted schemes for acquiring and analyzing the data.

Large-MSF plant dynamics were initially studied with a digital computer code that computed overall plant transfer functions of a linearized model, and the conclusion was that MSF stability characteristics are strongly dependent on the mechanisms that determine interstage tray brine flow rates. This conclusion was subsequently reinforced by use of a digital simulator that solves the. nonlinear model equations in the time domain.

The stability of the tray brine flow characteristics is related to the dependence of brine flow on downstream liquid levels, and the studies showed clearly that the higher the baffles downstream of the interstage orifice the greater the stability. Furthermore, it was shown that plants having a greater number of stages are more apt to be unstable, and that intuitive "fixes" of the MSF plant design using baffles might not be successful. Successful and unsuccessful attempts to stabilize a plant were made. In an unstable case, for example, five "high baffles" were added in stages $6,16,26,36$, and 46 of a 50 -stage plant in an attempt to decouple the plant into six sections. In a case resulting in a stable plant, tall baffles were used in each stage in the higher-temperature end of the plant, with the height gradually decreasing toward the lower-temperature end.

Besides the inherent tendencies for instabilities in a large MSF plant, it was also observed that the more closely the plant approaches a full dual-purpose plant design, the greater the tendency for instabilities to occur. This is shown in Fig. 27; the response of tray brine levels in stages 10, 20, and 30 in a 50-stage MSF plant model is stable when the brine heater steam temperature is controlled (as in a single-purpose plant) but is unstable when steam flow rate to the brine heater is controlled. An assumption in the latter case is that flow is controlled according to turbine requirements and correspunds closely to the case where (1) the steam comes from a back-pressure turbine (BPT) which comprises a small fraction of the total turbine plant output, and (2) the total plant electrical output is controlled by throttling the prime steam flow to the entire plant. The difference in stability characteristics for the two cases is due to perturbations in temperature of the inlet brine being attenuated in one case (temperature control) but not in the other. On the one hand, for flow control, since the heating rate for a given steam flow rate is nearly constant, a perturbation of 1 deg of the brine at the inlet will cause a I deg change in the brine outlet temperature. On the other hand, for temperature control, since the brine heater brine temperature is closely coupled to the steam temperature, only a fraction $(\sim 30 \%)$ of inlet brine temperature perturbations are seen at the outlet. 

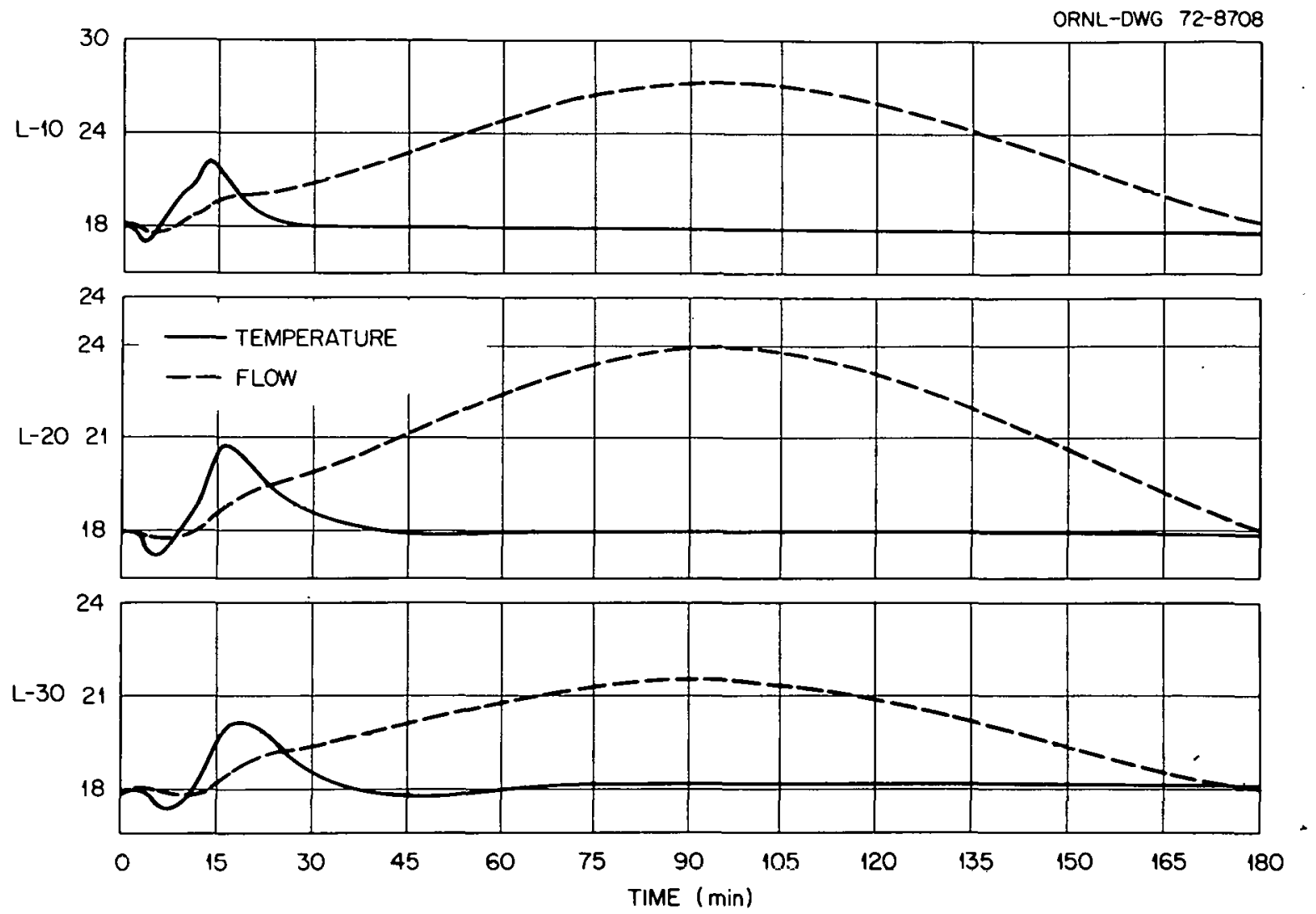

Fig. 27. Simulated response of stages 10, 20, and 30 tray brine levels in a 50 -stage MSF plant. Comparison of stability characteristics for brine heater steam flow control vs steam temperature control.

Another tendency toward destabilization was observed when the electrical output of the BPT generator was controlled directly. As before, the MSF plant models used in the two cases were identical, and a plant design that was stable under flow control was unstable when the electrical output was controlled. This destabilization is due to the fact that changes in brine heater conditions caused controlled steam flow changes which augmented, rather than attenuated, the effect of the initialing disturbance.

In conclusion, it should be noted that there may be some significant control problems in a given design of a large dual-purpose plant that depend both on the hydraulic design of the MSF plant stages and on the means of coupling to the turbine plant. However, the effective use of simulators for predicting coupled plant stability and controllability will depend strongly on the use of accurate correlations for the critical process performance characteristics. These are in turn strongly dependent on the specific hardware designs, and require comprehensive tests of the stage designs to be used. 
62

Blank 


\section{APPENDIX}

\section{Turbine and Cycle Criteria*}

Present day central station electric generating plants incorporate regenerative feedwater heating. The number of feedwater heaters (actually the number of stages of feed water heating) varies somewhat, depending upon the throttle pressure and temperature. In fossil fuel plants, the number of heaters may range from $5\left[8.6 \times 10^{6}\right.$ to $10 \times 10^{6} \mathrm{~Pa}(1250$ to $\left.1450 \mathrm{psig})\right]$ to $8\left[16.5 \times 10^{6}\right.$ and $24.1 \times 10^{6} \mathrm{~Pa}(2400$ and $3500 \mathrm{psig})]$. In nuclear fueled plants there are generally 6 or 7 heaters.

In practice, the heater extraction pressures are usually selected so that 5 to $7 \%$ of the turbine flow is extracted by each heater. The actual values are selected to satisfy the sometimes conflicting requirements of good blading efficiency and low thermodynamic losses in the feedheating process.

The extraction flows to the heaters vary almost linearly with turbine flow. This results in practically constant pressure ratio (constant heat drop) and consequently constant efficiency of the turbine stages (blading) between extraction points. When discontinuous or non-linear flow demands are imposed on the cycle, the turbine stage pressure ratios vary in like manner.

Increasing the flow demand at a given location will increase the pressure ratio and the torque loading on the upstream stages. The most adjacent upstream blade row has the greatest change in pressure ratio. The blading efficiency will decrease and the blade stresses will increase.

It may be possible to make the blade stronger but this invariably decreases the stage efficiency because this results in less optimum blading geomet ric proportions. If only steady stresses (bending and cent rifugal stresses, for example) were encountered, making a stronger mechanically satisfact ory blade would be comparatively simple. However, vibratory stresses are present and they increase as the blade pressure ratio is increased.

In addition, many manufacturers have blade styles in which the blade width and profiles are standardized. The standardized blade styles have pitch and height constraints which ensure that the thermodynamic performance and mechanical reliability are satisfactory.

Applications where unusually large amounts of mass flow are extracted at specific locations in the turbine (or where the variation of the extracted flow occurs at a much greater rate than the variation in turbine flow) will probably require custom made turbine designs.

For practical "standard" turbine designs, capable of operating in both the single and dual purpose mode. (simultanenus water and electric power production), a reasonable limit on extraction flow for the second and fourth cycles would be 363,000 to $454,000 \mathrm{~kg} / \mathrm{h}(800,000$ to $1,000,000 \mathrm{lb} / \mathrm{h}$ ) at rated load (for this application) for cycles without modulating control valves. This would correspond to 5.3 to $6.7 \%$ of rated steam gencrator flow.

* This section was prepared by George J. Silvestri, Steam Turbine Division, Westinghouse Ělectric Corporation Lester, Pennsylva nia under contract to Oak Ridge National Laboratory. 
Utilization of special tuned blades at these extraction locations (for each application) could extend the range of allowable extraction flow.

One of the objectives of this study was to establish the feasibility of using the various desalination cycles with standard nuclear turbines. The following sections will discuss the relative feasibility of the various cycle arrangements as well as the comparative efficiencies.

\section{Cycle Configurations}

\section{Base Cycle}

The standard or base cycle utilized a $3425 \mathrm{MW}(\mathrm{t})$ nuclear reactor. The $30 \gamma \mathrm{ps}$ ( $1800 \mathrm{rpm}$ ) turbine consisted of a high-pressure (HP) element and three double flow low-pressure (LP) elements with $1016-\mathrm{mm}\left(40\right.$-in.) last row blades. Throttle steam conditions were $6614-\mathrm{kPa}\left(960\right.$-psia). $282^{\circ} \mathrm{C}\left(540^{\circ} \mathrm{F}\right)$. $0.4 \%$ moisture. The cycle incorporated an external moisture separator and two stages of steam-to-steam reheat at the HP element cxhaust.

Rated steam generator flow was $6,940,000 \mathrm{~kg} / \mathrm{h}(15.100,000 \mathrm{lb} / \mathrm{h})$. The HP element exhaust conditions were $1248 \mathrm{kPa}(181 \mathrm{psia}), 189^{\circ} \mathrm{C}\left(373^{\circ} \mathrm{F}\right)$ and $12.4 \%$ moisture with a flow of $5,653,000 \mathrm{~kg} / \mathrm{h}$ $(12,462,000 \mathrm{lb} / \mathrm{h})$. LP elements inlet conditions were $1131 \mathrm{kPa}(164 \mathrm{psia}), 268^{\circ} \mathrm{C}\left(514^{\circ} \mathrm{F}\right)$ and a flow of $4,589,000 \mathrm{~kg} / \mathrm{h}(10,116,000 \mathrm{lb} / \mathrm{h})$. LP element exhaust conditions were $11.8 \mathrm{kPa}(3.5 \mathrm{in} . \mathrm{HgA}), 49^{\circ} \mathrm{C}$ $\left(121^{\circ} \mathrm{F}\right.$ ) and a flow of $3,536,000 \mathrm{~kg} / \mathrm{h}(7,796.000 \mathrm{lb} / \mathrm{h}$ ). The latter three conditions ( $\mathrm{HP}$ exhaust, I.P inlet and $L P$ exhaust) relate to the base cycle only and correspond to rated throttle flow.

The cycle had seven feedwater heaters (see Fig. Al). The four lowest pressure feedwater heaters extracted from the LP element. The fifth feedwater heater extracted from the HP exhaust. The sixth and seventh feed water heaters extracted from the HP element. The cycle utilized a steam turbine drive. FPT, for the feed pump. This turbine drive was supplied with steam from the Moisture SeparatorReheater (MSR) exhaust. The leed pump was located between the sixth and seventh feed water heaters. In addition. to facilitate drainage, the water from the moisture separator was sent to a separate heat exchanger interspersed between the fourth and fifth feedwater heaters.

1 urbıne output at the rated reactor power (rated. $100 \%$. throttle flow) was $1174.8 \mathrm{MW}(\mathrm{e})$ with a turbine exhaust (condenser) pressure of $11.8 \mathrm{kPa}$ abs (3.5 in. HgA). At $5.1 \mathrm{kPa}$ abs ( $1.5 \mathrm{in}$. HgA) turbine output was $1197.4 \mathrm{MW}(\mathrm{e})$ and was $1126.8 \mathrm{MW}(\mathrm{e})$ at $18.6 \mathrm{kPa}$ abs (5.5 in. $\mathrm{HgA}$ ). It must be emphasized that most current Westinghouse steam turbine designs have maximum allowable exhaust pressures of $18.6 \mathrm{kPa}$ abs (5.5 in. $\mathrm{HgA})$.

\section{Zeresh Cycle}

Israel Desalination Engineering Ltd. (IDE) has developed a multieffect distillation type, "Zeresh," desalination process. This process is especially suited to applications utilizing "standard" nuclear power turbines operating at conventional exhaust pressures. The Zeresh process uses turbine exhaust steam at considerably lower pressures than other desalination processes. In an Israeli study of a dual-purpose nuclear power/desalination plant. it was found that water cost did not vary appreciably for turbine exhaust pressures between 16.9 and $23.7 \mathrm{kPa}(5.0$ and $7.0 \mathrm{in} . \mathrm{HgA}){ }^{41}$

While the maximum allowable exhaust pressure of most Westinghouse steam turbines is $18.6 \mathrm{kPa}$ (5.5 in. $\mathrm{HgA}$ ), the most recent Westinghouse $1800 \mathrm{rpm}$ LP element designs $[1016$ and $1118 \mathrm{~mm}$ (40 and $44 \mathrm{in.}$ ) last row blades] allow limited operation up $1027 . / \mathrm{kPa}(8.0 \mathrm{in}$. $\mathrm{HgA}$ ). The allowable duration is limited to a maximum of 72 days or part days in any 12 -month period provided that such operation is in accordance with specific guidelines and at loads (exhaust flows) that are above an established level. 
ORNL-DWG 79-17207 ETD

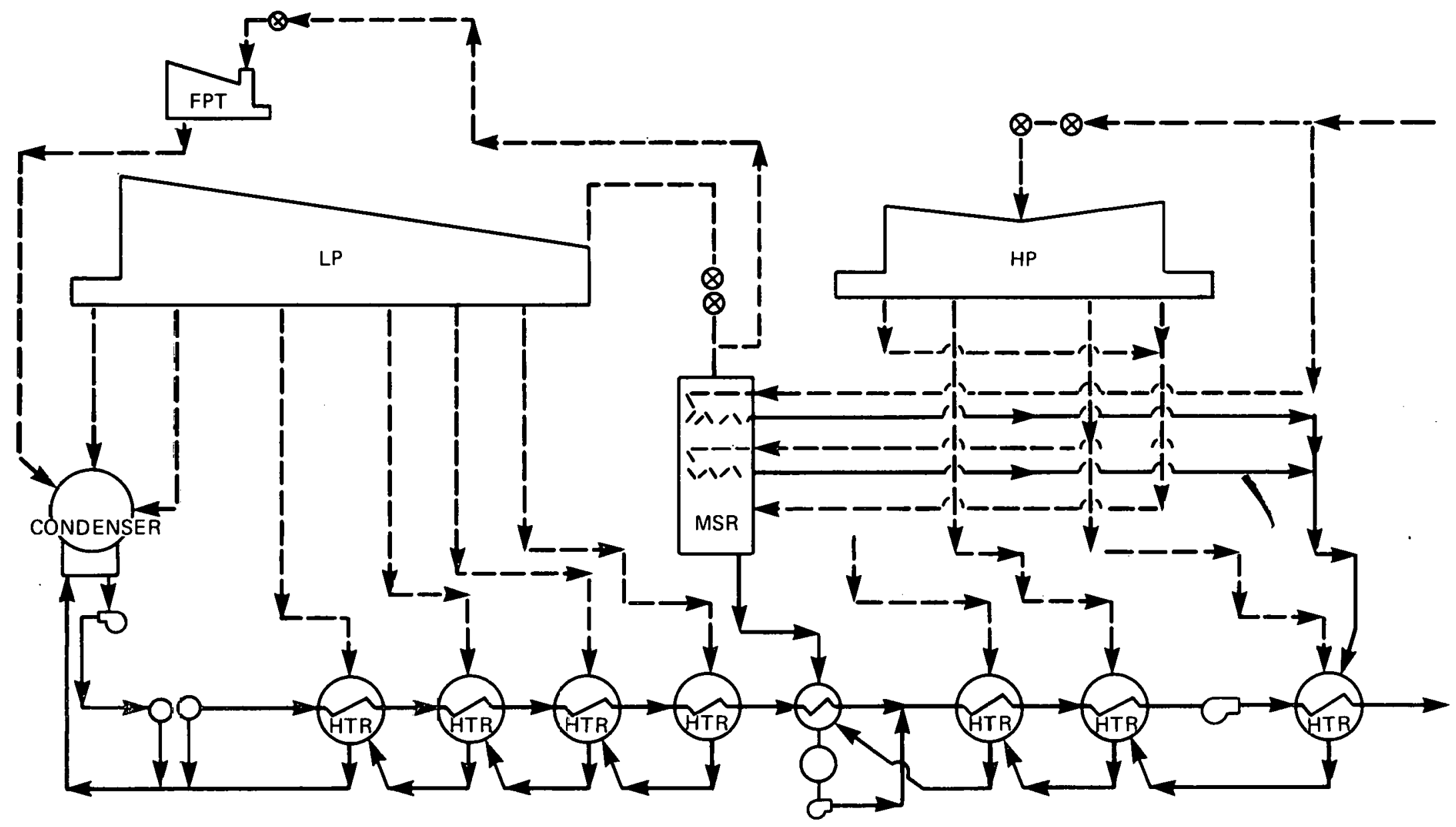


The turbine selected for this study used this design and so calculations were made for exhaust pressures up to $27.1 \mathrm{kPa}(8.0 \mathrm{in}$. $\mathrm{HgA})$. Turbine performance at $18.6 \mathrm{kPa}(5.5 \mathrm{in}$. $\mathrm{HgA})$ and below is identical with that of the base case. At $27.1 \mathrm{kPa}(8.0 \mathrm{in}$. $\mathrm{HgA})$, the turbine output is $1077.2 \mathrm{MW}(\mathrm{e})$.

The heat transfer surface of the dual-purpose condenser is almost $100 \%$ larger than that of a single-purpose unit, requiring a condenser which is approximately $30 \%$ larger in external dimensions. These increases are a result of the smaller circulating water temperature rise [for example, $4.4^{\circ} \mathrm{C}\left(8^{\circ} \mathrm{F}\right.$ ) vs $13.9^{\circ} \mathrm{C}\left(25^{\circ} \mathrm{F}\right)$ and the larger flows (cooling water) of the dual purpose condenser]. The foregoing values were established in the study reported in Ref. $4 \mathrm{l}$ as part of the economic evaluation.

The turbine cycle arrangement would be similar to Fig. A2.

With the Zeresh process, when turbine throttle flow (load) is reduced, both water production and turbine exhaust pressure decrease. The latter item is important as last stage blade flutter may be encountered if exhaust volumetric flow is excessively low. A recent studv of a $945 \mathrm{MW} / 100 \mathrm{Mgd}$ $\left(378,500 \mathrm{~m}^{3} / \mathrm{d}\right)$ dual-purpose plant indicated that turbine exhaust pressure decreased frnm $18.6 \mathrm{kPa}$ (5.5 in. $\mathrm{HgA})$ at rated load to $8.5 \mathrm{kPa}(2.5 \mathrm{ln} . \mathrm{HgA})$ at $15 \%$ load.

One of the major advantages of the Zeresh process is that available standard turbine designs can be used. In addition, all of the turbine exhaust energy can be used in the desalination plant. In contrast, the. a mount of steam that can be removed with single or multiple extractions points on standard turbines is limited because of mechanical and fluid dynamic considerations. For example, the turbine exhaust can deliver between $80.2 \times 10$ and $84.4 \times 10^{8} \mathrm{~kJ} / \mathrm{h}\left(76.0 \times 10^{8}\right.$ and $\left.80 \times 10^{8} \mathrm{Btu} / \mathrm{h}\right)$ to the Zeresh process while practical extraction cycles can deliver just a fraction of this with standard turbines.

The Zeresh process will distill less water per unit of heat than other processes. The condenser is also larger than that for other plants. The distillation plant may be more ex pensive (per unit of product) with the Zeresh process but there is less loss in plant electrical output.

\section{HP Exhaust Extraction Cycle}

This configuration extracts steam at the HP element exhaust. The remainder of the turbine cycle is identical with the base cycle (see rig. A3).

Since water is storable and electricity is not readily storable, there will be periods when the plant will operate in the single-purpose mode or when the desalting plant will not be producing rated water output.

This variation in water plant output (for a given turbine throttle flow) causes a variation in HP element exhaust pressure and, consequently, variation in the pressure ratio (pressure drop) of the terminal stages of the HP element. This could cause excessive pressure ratios and stresses for these stages. For practical turbine designs, this will limit the amount of flow that can he extracted at the HP exhaust. The variation in stage pressure will also reduce the turbine efficiency.

The amount of extracted flow can be increased by inserting modulating valves at the LP inlet.* These valves would hold the HP exhaust pressure to a preprogrammed level to avoid excessive pressure ratio on the HP stages. The valves will cause a loss in efficiency by throttling to the LP inlet blading pressure level.

All of the plant cycles used the same turbine designs for the main generating unit. The variation in stage pressure ratios caused by desalination plant energy demand was considered in establishing reasonable extraction flow limits.

*The valves on current designs do not modulate. They are either fully open or closed. 
ORNL-DWG 79-17208 ETD

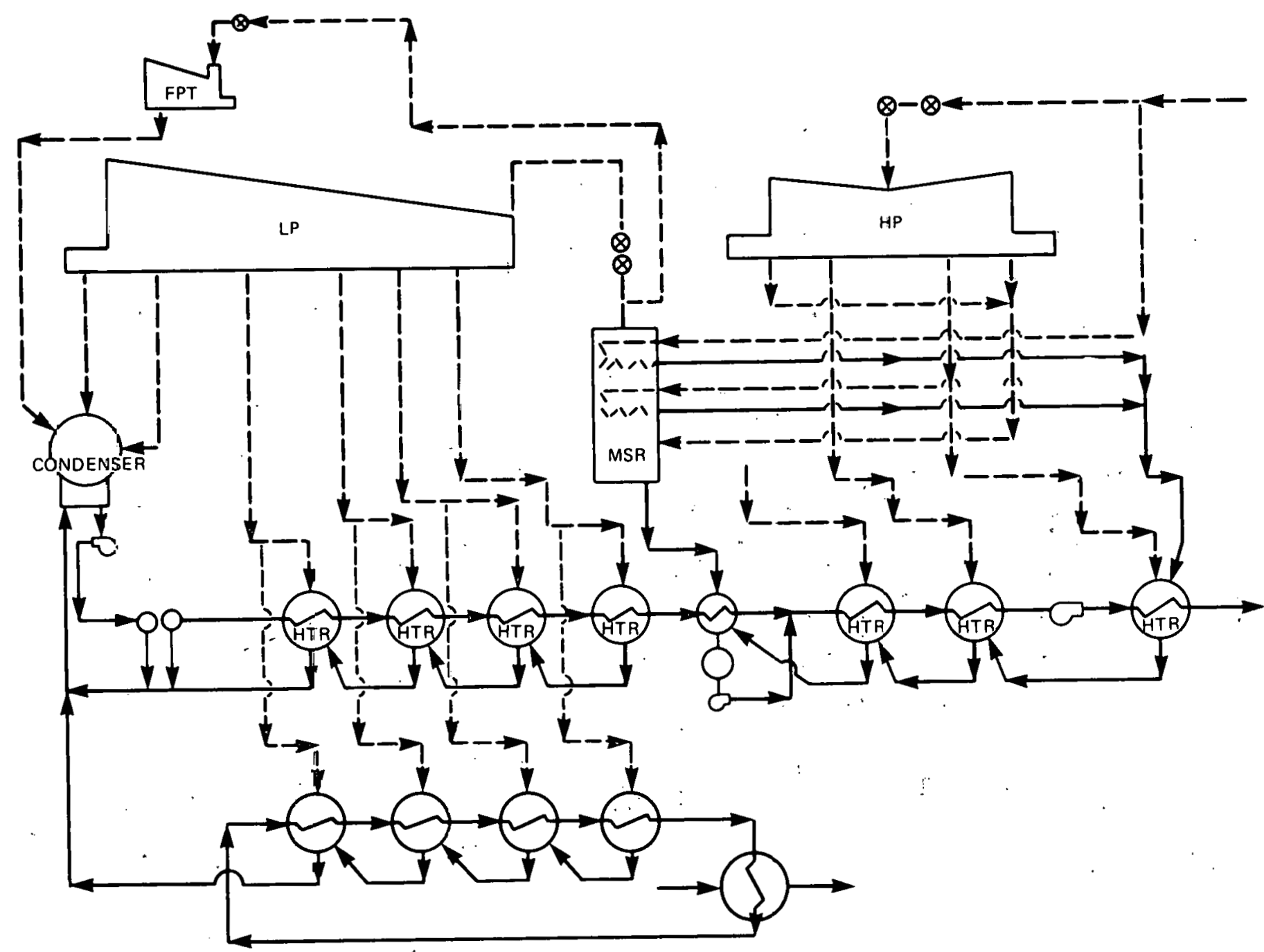

Fig. A2 
ORNL-OWG 79-17209 ETD

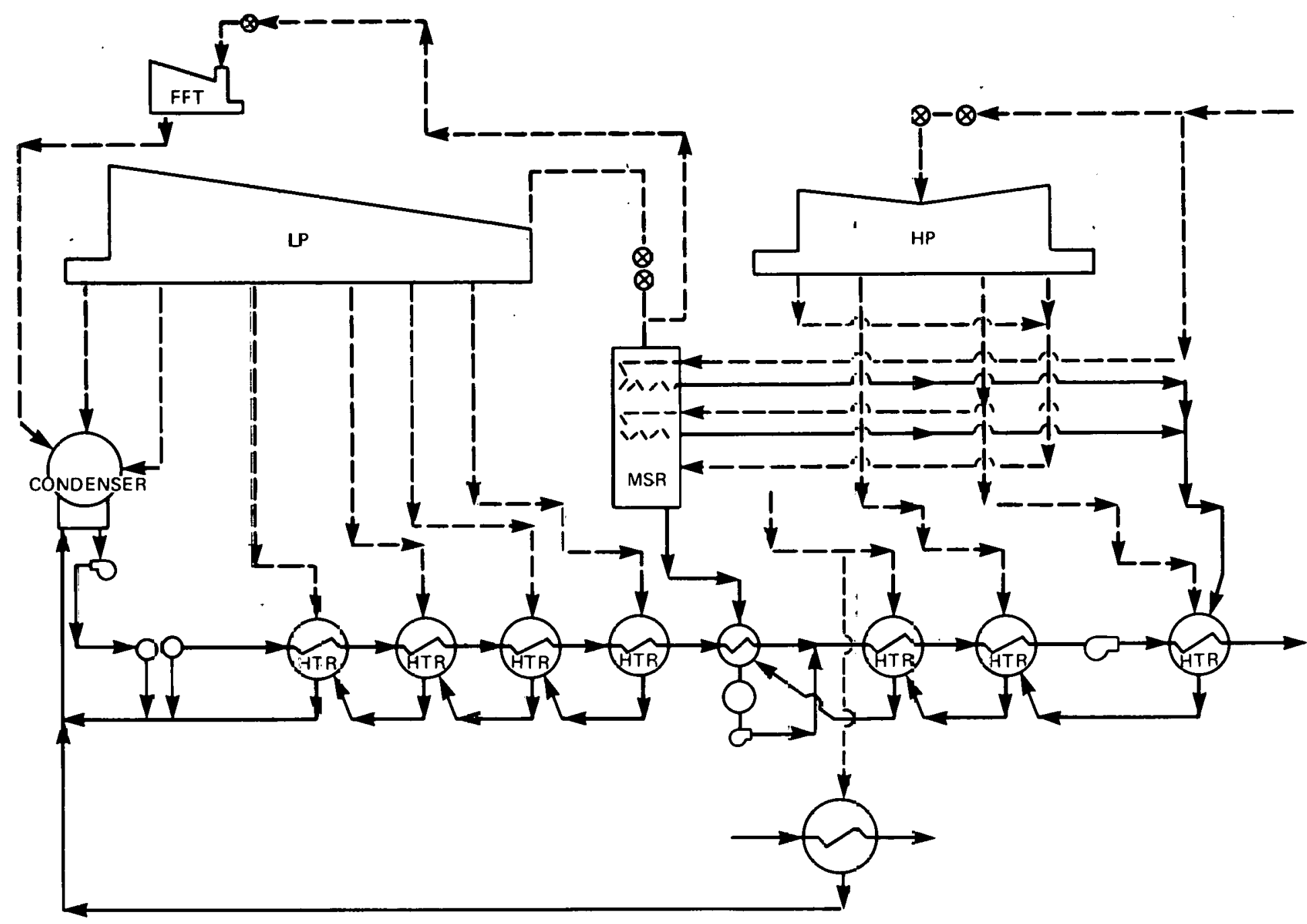

Fig. A3 
Calculations for this cycle were made with and without modulating valves at inlet to the LP element.

\section{Multiple LP Extraction Cycle}

For this cycle the brine for the desalination plant was sent through four successive heaters bleeding steam from progressively higher-pressure extraction points in the LP element (see Fig. A4). In this way the heat load for the desalination process was spread over four extraction points instead of being taken from one location. This is a more efficient cycle than the single extraction point arrangement. More importantly, the variation in stage pressure ratio and $\mathrm{HP}$ exhaust pressure is much less severe than with a cycle with a single bleed point (similar to the one discussed in the previous section).

It appears feasible to extract a total of about $1,270,000 \mathrm{~kg} / \mathrm{h}(2.800,000 \mathrm{lb} / \mathrm{h})$ with this cycle at rated plant output for the turbine elements considered in this study. This represents about $18.5 \%$ of rated steam generator flow. The extraction conditions are as follows:

\begin{tabular}{rccr}
\hline $\begin{array}{c}\text { Pressure } \\
\mathrm{KPa} \text { abs (psia) }\end{array}$ & $\begin{array}{c}\text { Temperature } \\
{ }^{\circ} \mathrm{C}\left({ }^{\circ} \mathrm{F}\right)\end{array}$ & $\begin{array}{c}\text { Moisture } \\
\%\end{array}$ & $\begin{array}{c}\text { Flow } \\
\mathrm{kg} / \mathrm{s}(\mathrm{lb} / \mathrm{h})\end{array}$ \\
\hline $24.8(3.6)$ & $64.4(149)$ & 8.1 & $51.9(412.000)$ \\
$75.8(11.0)$ & $91.6(197)$ & 6.1 & $85.8(681.000)$ \\
$213.7(31.0)$ & $122.2(252)$ & 1.6 & $102.1(810.000)$ \\
$510.2(74.0)$ & $188.3(371)$ & & $108.5(861.000)$ \\
\hline
\end{tabular}

The limiting flow criteria for this cycle would be extraction slot pressure drop and possible blade excitation.

A patent will be issued shortly to A. E. Becker and R. O. Brown, Westinghouse Steam Turbine Division employees, who developed this cycle arrangement.

\section{High Exhaust Pressure Turbine Cycle}

This cycle takes steam leaving the MSR and sends a portion of it to a high exhaust pressure (back-pressure) turbine. The high exhaust pressure turbine sends its exhaust to the desalination process. In this study, the high exhaust pressure turbine operated at $103 \mathrm{kPa}$ (15.0 psia) (see Fig. A5). The Back-Pressure Turbine is designated as BPT on Fig. $\wedge 3$.

Calculations were made with and without modulating valves at inlet to the LP element. The purpose of the valves was identical with those in the "HP Exhaust Extraction Cycle."

The extraction point for this turbine was from the reheater exhaust in order to reduce the turbine moisture and improve cycle efficiency.

\section{Comparative Cycle Results}

The rated condenser pressure of the base or standard single-purpose plant, Fig, A2, was $11.8 \mathrm{kPa}$ (abs) (3.5 in. $\mathrm{HgA}$ ). This resulted in a net turbine output of $1174.8 \mathrm{MW}(\mathrm{e})$ at rated throttle flow (rated reactor output).

Turbine exhaust pressure increases when the Zeresh process (Fig. A3 also) is used to make water. As was mentioned earlier, an Israeli study indicated that the optimum dual-purpose plant had a turbine exhaust pressure of 16.9 to $23.7 \mathrm{kPa}$ (5.0 to $7.0 \mathrm{in}$. $\mathrm{HgA}$ ). At $16.9 \mathrm{kPa}$ (5.0 in. $\mathrm{HgA}$ ) the turbine output 


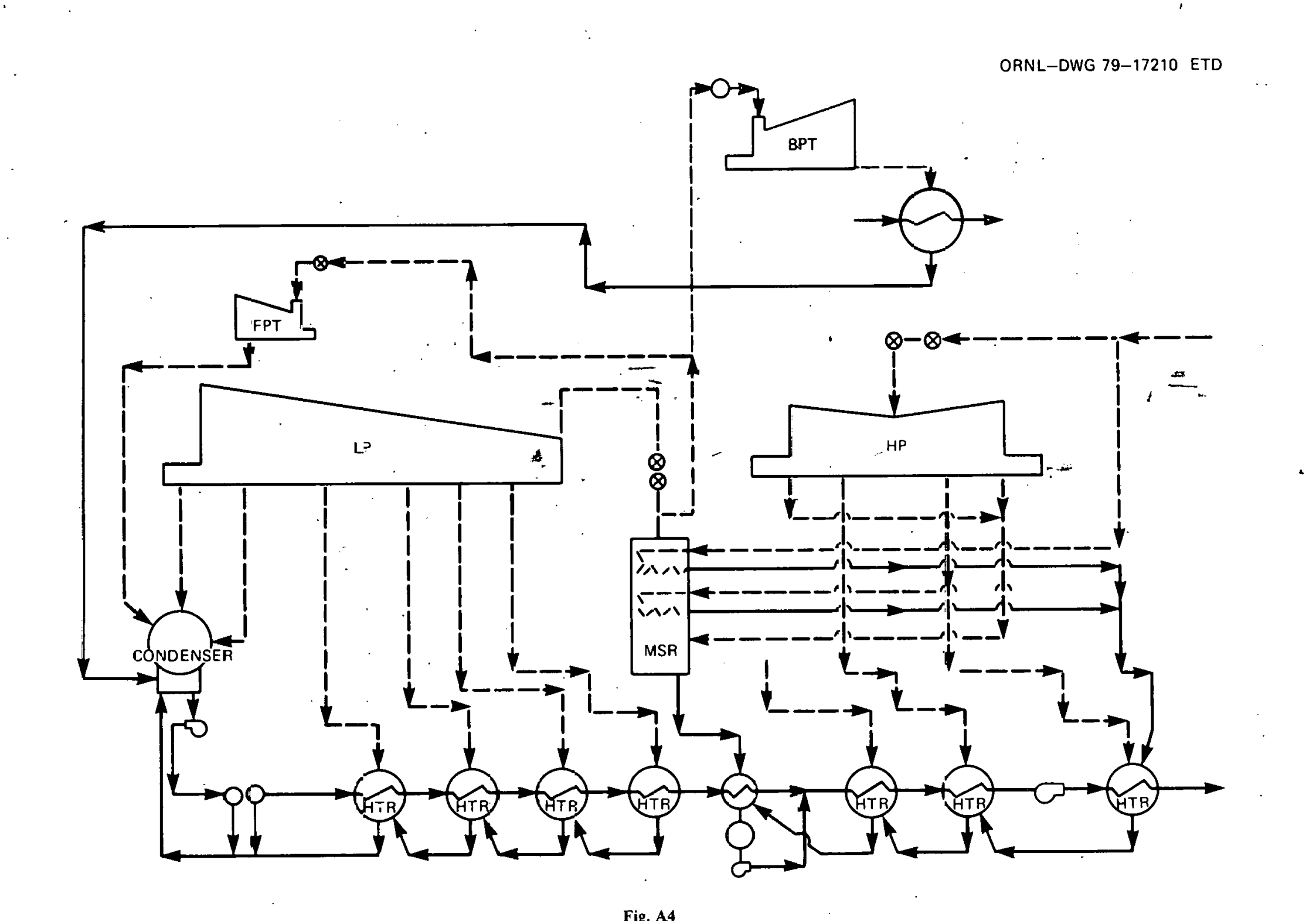




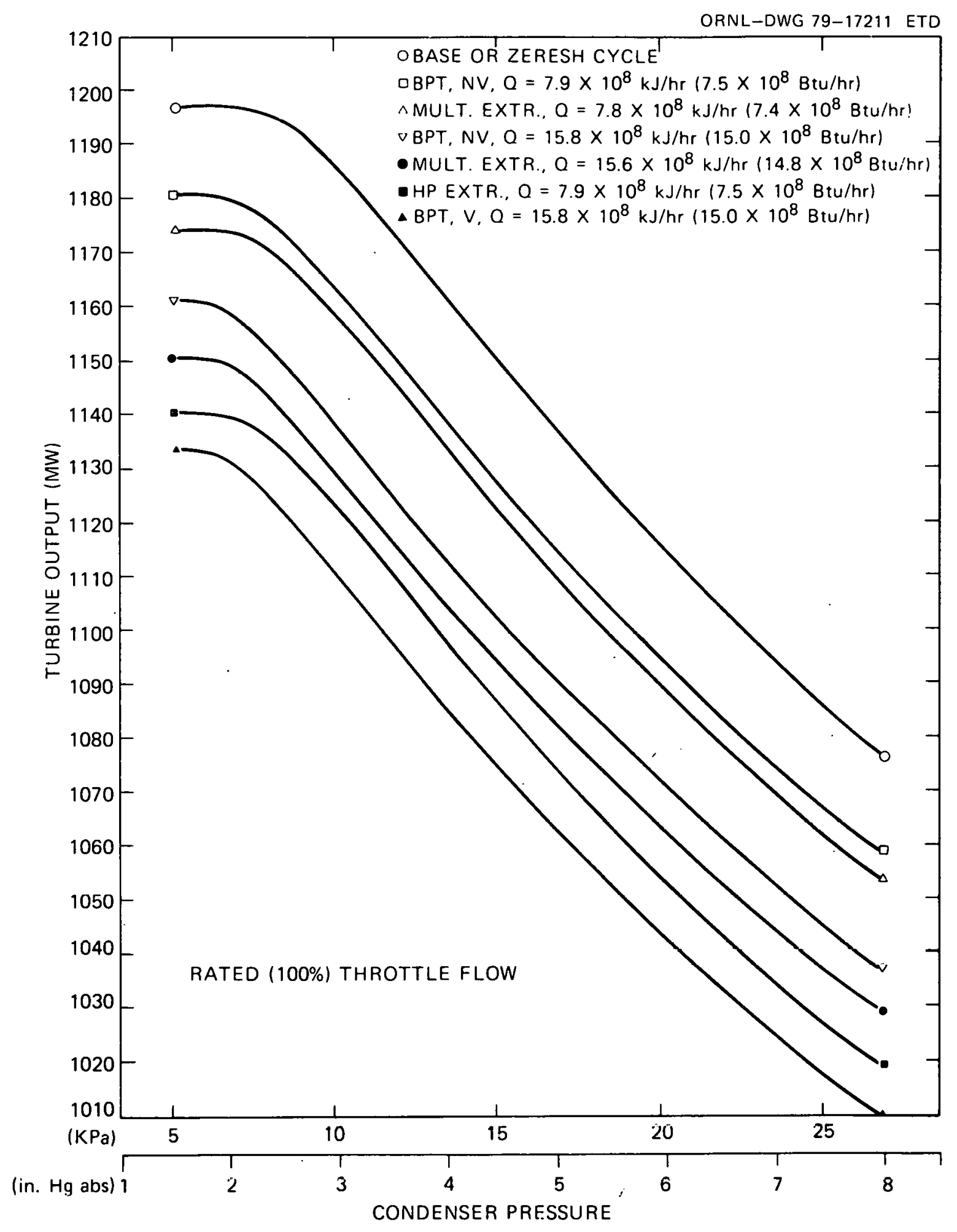

Fig. A5 : 
would be $1138.3 \mathrm{MW}(\mathrm{e})$, a loss of $36.5 \mathrm{MW}(\mathrm{e}) .3 .1 \%$, when compared to the base plant. This data is presented in Table A.1. At $23.7 \mathrm{kPa}(7.0 \mathrm{in}$. $\mathrm{HgA})$, the loss in output is $79.3 \mathrm{MW}(\mathrm{e}), 6.7 \%[1095.5$ $\mathrm{MW}(\mathrm{e})$ vs $1174.8 \mathrm{MW}(\mathrm{e})]$.

Table A I

\begin{tabular}{|c|c|c|c|c|}
\hline Cycle & $\begin{array}{l}\text { Hcat load } \\
\text { k. h } \times 10^{s} \\
\left(\text { Biu } h \times 10^{s}\right)\end{array}$ & $\begin{array}{c}\text { Condenser } \\
\text { pressure } \\
\text { kPa (in. Hy A.) }\end{array}$ & $\begin{array}{l}\text { Turbine } \\
\text { output } \\
\text { (MW) }\end{array}$ & Comments \\
\hline Base & 0 & $11.8(3.5)$ & 1174.8 & \\
\hline \multirow[t]{3}{*}{ Zeresh Process } & $8.2(7.8)$ & $16.9(5.0)$ & 11.38 .3 & $a$ \\
\hline & $8.3(7.8)$ & $18.6(5.5)$ & 1126.9 & \\
\hline & $8.4(7.9)$ & $23.6(7.0)$ & 1095.5 & \\
\hline \multirow[t]{5}{*}{ HP Fxh. Fxtraction } & $7.9(7.5)$ & $11.8 \quad(3.5)$ & 1111.3 & No salie throttling \\
\hline & $15.8(15.0)$ & $11.8(3.5)$ & 1048.9 & No value throutling \\
\hline & $7.9(7.5)$ & $1 !, 8(3,5)$ & 1094.4 & Valve throttling \\
\hline & $148 ! 14 \| !$ & $11 \times 1331$ & 1111.3 .4 & Valse throfllin! \\
\hline & $31.6(.30 .0)$ & $11.8(3.5)$ & 851.0 & Valec throutling \\
\hline \multirow[t]{3}{*}{ Multiple I.P Extraction } & $7.8(7.4)$ & $11.8(3.5)$ & 1146.5 & No valve throttling \\
\hline & $15.6(14.8)$ & $11.8(3.5)$ & 1117.6 & No valve throttling \\
\hline & $.30 .7(29.1)$ & $11.8(3.5)$ & 1060.7 & No valse throutling: \\
\hline \multirow[t]{4}{*}{ High Exh. Pressure Turbine } & $7.9(7.5)$ & $11.8(3.5)$ & 1151.7 & No valse throutling \\
\hline & $15.8(15.0)$ & $11.8(3.5)$ & 1125.9 & No value throllting \\
\hline & $15.8(15.0)$ & $11.8(3.5)$ & 1098.6 & Valie throttling \\
\hline & $31.6(30.0)$ & $11.8(3.5)$ & 1022.4 & Valve throttling \\
\hline
\end{tabular}

"If only one I.P element were supplying heat to the desalination process. the turbine ouput would be $1162.6 \mathrm{MW}$ with a heat load of $2731 \times 10^{\mathrm{\prime}} \mathrm{k.l}$ h $\left(2601 \times 10^{\mathrm{\prime}} \mathrm{B}(\mathrm{ll} \mathrm{h})\right.$.

The turbine in this study had three double llow L.P elements. It would be possible to have I wo of the $L P$ elements exhausting to conventional condensers and the third LP element supplying heat to the desalination process. In this case the loss in output would be $12.2 \mathrm{MW}(\mathrm{e})$ at $16.9 \mathrm{kPa}(5.0 \mathrm{in}$. $\mathrm{HgA}$ )(for the turbine exhausting to the desalination process) and $26.4 \mathrm{M} \mathrm{W(e)} \mathrm{at} 23.7 \mathrm{kPa}(7.0 \mathrm{in}$. HyA). The lieal supplied to the desalination process would be $27.4 \times 10^{*}$ and $28.0 \times 10^{*} \mathrm{~kJ} / \mathrm{h}\left(26.0 \times 10^{\prime \prime}\right.$ and $26.5 \times 10^{\prime \prime}$ $\mathrm{Btu} / \mathrm{h}$ ), respectively. This is still considerably more heat than is practical to remove with the other desalination concepts (single HP extraction, multiple LP extraction and high exhaust pressure turbine cycle) while still using standard design turbine elements.

The plant performance with these other desalination processes was more sensitive to the amount of heat supplied to the desalination plant. However, the variation in plant output was practically linear with heat supply from 0 to $30.0 \times 10^{x} \mathrm{Btu} / \mathrm{h}\left(0\right.$ to $88 \times 10^{8}$ watts, or $\left.31.6 \times 10^{\mathrm{x}} \mathrm{kJ} / \mathrm{h}\right)$.

The desalination cycle with a single extraction at the HP exhaust. Fig. A.I, had the largest loss of output (Table A.1) as well as the largest change in HP exhaust pressure (Table A.2). With a heat load of $7.9 \times 10^{\mathrm{K}} \mathrm{kJ} / \mathrm{h}\left(7.5 \times 10^{\mathrm{x}} \mathrm{Btu} / \mathrm{h}\right)$, the loss in output was $63.5 \mathrm{MW}(\mathrm{e})$ as compared to $36.5 \mathrm{MW}(\mathrm{e})$ at 16.9 $\mathrm{kPa}(5.0 \mathrm{in} . \mathrm{HgA})$ and $79.3 \mathrm{MW}(\mathrm{e})$ at $23.7 \mathrm{kPa}(7.0 \mathrm{in} . \mathrm{HgA})$ for the Zeresh process. ${ }^{*}$ With a heat load of $15.8 \times 10^{\mathrm{K}} \mathrm{kJ} / \mathrm{h}\left(15.0 \times 10^{\mathrm{K}} \mathrm{Btu} / \mathrm{h}\right)$, the loss in output was $125.9 \mathrm{MW}(\mathrm{e})$.

This single HP exhaust extraction caused sizeable changes in HP exhaust pressure. The base cycle had an $\mathrm{HP}$ exhaust pressure of $1244 \mathrm{kPa}$ (180.5 psia). The pressure decreased to $1127 \mathrm{kPa}$ (163.6 psia)

*The heat load of $7.88 \times 10^{\mathrm{h}} \mathrm{kJ} / \mathrm{hr}\left(7.5 \times 10^{8} \mathrm{Btu} / \mathrm{h}\right)$ corresponds to an extraction flow of $1260 \mathrm{~kg} / \mathrm{s}(1,000,000 \mathrm{lbs} / \mathrm{h})$ at 1128 $\mathrm{kPa}(\mathrm{abs})(163.6 \mathrm{psia}), 185^{\circ} \mathrm{C}\left(365^{\circ} \mathrm{F}\right)$ and $12.6 \%$ moisture. 
Table A2

\begin{tabular}{|c|c|c|c|}
\hline Cycle & $\begin{array}{c}\text { Heat load } \\
\text { kJ'h } \times 10^{*} \\
\left(B+u^{\prime} h \times 10^{x}\right)\end{array}$ & $\begin{array}{l}\text { HP exhaust } \\
\text { pressure } \\
M P a(p s i a)\end{array}$ & Comments \\
\hline Basc & 0 & $1.25(180.5)$ & \\
\hline Zeresh Process & $8.2-8.4(7.8-8.0)$ & $1.25(180.5)$ & \\
\hline \multirow[t]{3}{*}{ HPExh. Extraction } & $7.9(7.5)$ & $1.1 .3(163.6)$ & No valve throttling \\
\hline & $15.8(15.0)$ & $1.01(147.0)$ & No valve throttling \\
\hline & $a$ & $1.25(180.5)$ & Valve throttling \\
\hline \multirow[t]{3}{*}{ Multiple I.P Extraction } & $7.8(7.4)$ & $1.2 .3(178.8)$ & No valve throttling \\
\hline & $15.6(14.8)$ & $1.22(177.0)$ & No valve throttling \\
\hline & $30.7(29.1)$ & $1.19(17.3 .1)$ & No value throttling \\
\hline \multirow[t]{3}{*}{ High Exh. Pressure Turbine } & $7.9(7.5)$ & $1.1 .3(164.1)$ & No valve throttling \\
\hline & $15.8(15.0)$ & $1.02(147.8)$ & No valve throttling \\
\hline & $a$ & $1.25(180.5)$ & Valve throttling \\
\hline
\end{tabular}

"Heat l.oad does not influence HP Exhaust Pressure. It does affect the amount of valve throttling.

and $965 \mathrm{kPa}(140.0 \mathrm{psia})$ with heat loads of $7.9 \times 10^{8}$ and $15.8 \times 10^{8} \mathrm{~kJ} / \mathrm{h}\left(7.5 \times 10^{8}\right.$ and $15.0 \times 10^{8}$ $\mathrm{Btu} / \mathrm{h})$, respectively. These represent sizeable changes in the HP exhaust pressure.

In contrast, the desalination cycle with multiple LP extraction points had a lower loss in output and a much less change in HP exhaust pressure than the single HP extraction point. The loss in output was $28.3 \mathrm{MW}(\mathrm{e})$ with a heat load of $7.8 \times 10^{\mathrm{8}} \mathrm{kJ} / \mathrm{h}\left(7.4 \times 10^{8} \mathrm{Btu} / \mathrm{h}\right)$ and $57.2 \mathrm{MW}(\mathrm{e})$ with a heat load of $15.6 \times 10^{\mathrm{R}} \mathrm{kJ} / \mathrm{h}\left(14.8 \times 10^{\mathrm{B}} \mathrm{Btu} / \mathrm{h}\right)\left(\right.$ see Table A.1). ${ }^{*}$ In addition, the $\mathrm{HP}$ exhaust pressure decreased by only 11.7 and $24.1 \mathrm{kPa}(1.7$ and $3.5 \mathrm{psia})$ with heat loads of 7.8 and $15.6 \times 10^{8} \mathrm{~kJ} / \mathrm{h}\left(7.4 \times 10^{8}\right.$ and $14.8 \times$ $\left.10^{8} \mathrm{Btu} / \mathrm{h}\right)$, respectively. In fact, it was possible to supply a heat load of $30.7 \times 10^{8} \mathrm{~kJ} / \mathrm{h}\left(29.1 \times 10^{8}\right.$ $\mathrm{Btu} / \mathrm{h}$ ) with only a $51 \mathrm{kPa}(7.4 \mathrm{psia}), 4.1 \%$ change in $\mathrm{HP}$ exhaust pressure (see Table A.2). Also, there is less loss in output for the multiple extraction cycle, $114.1 \mathrm{MW}(\mathrm{e})$, with a heat load of $30.7 \times 10^{8} \mathrm{~kJ} / \mathrm{h}$ $\left(29.1 \times 10^{8} \mathrm{Btu} / \mathrm{h}\right)$ than the single extraction cycle, $125.9 \mathrm{MW}(\mathrm{e})$, with a heat load of $15.8 \times 10^{8} \mathrm{~kJ} / \mathrm{h}$ $\left(15.0 \times 10^{8} \mathrm{Btu} / \mathrm{h}\right)$.

For the cycle with a back-pressure turbine, Fig. A5, which ext racts from the HP exhaust, the loss in turbine output was $23.1 \mathrm{MW}(\mathrm{e})$ with a heat load of $7.9 \times 10^{8} \mathrm{~kJ} / \mathrm{h}\left(7.5 \times 10^{8} \mathrm{Btu} / \mathrm{h}\right)$ and $48.9 \mathrm{MW}(\mathrm{e})$ with a heat load of $15.8 \times 10^{8} \mathrm{~kJ} / \mathrm{h}\left(15.0 \times 10^{8} \mathrm{Btu} / \mathrm{h}\right){ }^{* * *}$. The cycle performance was only slightly better than the multiple LP extraction cycle: $5.2 \mathrm{MW}(\mathrm{e})$ more output at $7.9 \times 10^{8} \mathrm{~kJ} / \mathrm{h}\left(7.5 \times 10^{8} \mathrm{Btu} / \mathrm{h}\right)$ and $12.5 \mathrm{MW}(\mathrm{c})$ at $15.8 \times 10^{8} \mathrm{~kJ} / \mathrm{h}\left(15.0 \times 10^{8} \mathrm{Btu} / \mathrm{h}\right)($ see Tahle. A. 1$)$. The hack-pressure turbine produces $40.8 \mathrm{MW}(\mathrm{e})$ with a heat load of $7.9 \times 10^{8} \mathrm{~kJ} / \mathrm{h}\left(7.5 \times 10^{8} \mathrm{Btu} / \mathrm{h}\right)$ and $78.2 \mathrm{MW}(\mathrm{e})$ with a heat load of 31.7 $\times 10^{8} \mathrm{~kJ} / \mathrm{h}\left(30.0 \times 10^{8} \mathrm{Btu} / \mathrm{h}\right)$.

This cycle would require the development of a back-pressure turbine. In addition this cycle resulted in large changes in HP exhaust pressure (see Table A.2).

Because of the large changes in HP exhaust pressure that occur with the single extraction point cycle, Figs, A4 and A5, the maximum desalination plant heat load that was considered was $15.8 \times 10^{8}$ $\mathrm{kJ} / \mathrm{h}\left(15.0 \times 10^{8} \mathrm{Btu} / \mathrm{h}\right)$. The change in HP exhaust pressure was considerable, about $13 \%$. Even the value at $7.9 \times 10^{8} \mathrm{~kJ} / \mathrm{h}\left(7.5 \times 10^{8} \mathrm{Btu} / \mathrm{h}\right)$ was large, about $9 \%$. It would be possible to accom modate this

*The attainment of a given heat load was an iterative process for this cycle. It was impractical to achieve values of exactly $7.9 \times 10^{8}$ and $415.8 \times 10^{8} \mathrm{~kJ} / \mathrm{h}\left(7.5 \times 10^{8}\right.$ and $\left.15.0 \times 10^{8} \mathrm{Btu} / \mathrm{h}\right)$ because of the large number of computer runs that would be required.

*** The heat load of $7.9 \times 10^{\mathrm{*}} \mathrm{kJ} / \mathrm{h}\left(7.5 \times 10^{\mathrm{8}} \mathrm{Btu} / \mathrm{h}\right)$ corresponds to a flow of $100.8 \mathrm{~kg} / \mathrm{s}(800.000 \mathrm{lb} / \mathrm{h})$ at $1055 \mathrm{kPa}(\mathrm{abs})(153$ psia) and $2688^{\circ} \mathrm{C}\left(516^{\circ} \mathrm{F}\right)$. 
latter heat load. However, there may be some impairment in turbine efficiency because wider, stronger blades may be needed.

The desalination cycles with the single extraction point (either exhausting directly to the desalination process or to the back-pressure turbine) could ex tract 363,000 to $454,000 \mathrm{~kg} / \mathrm{h}(800,000$ to $1,000,000 \mathrm{lb} / \mathrm{h}$ ) at rated throttle flow with standard turbine designs. These values represent 5.3 to $6.7 \%$ of the rated steam generator flow. For other dual-purpose applications (different plant ratings and turbine element selections), a reasonable approximation for the allowable extraction flow would be the percentage values mentioned in the previous statement.

Inclusion of modulating valves to maintain $\mathrm{HP}$ exhaust pressure at the desired level will result in the ability to extract much more steam for desalination. This advantage is offset by the fact that the valves must throttle, thereby reducing plant output. The limit on extraction flow with modulating valves would be the cooling steam requirements of the LP elements.

With the valves maintaining $\mathrm{H} P$ exhaust pressure at a predet ermined Icvcl, calculations were miade for the H P exhaust extraction cycle and the high exhaust pressure turbine cycle. In each case the steam supply for the desalination process was extracted prior to the throttling valves.

With heat loads of only $7.9 \times 10^{8} \mathrm{~kJ} / \mathrm{h}\left(7.5 \times 10^{8}\right.$ Btu/h). the HP exhaust pressure changed by about $9 \%$ when a single extraction point was used in the-cycles without valves. For a heat load of $7.9 \times 10^{\circ} \mathrm{kJ} / \mathrm{h}\left(7.5 \times 10^{8} \mathrm{Btu} / \mathrm{h}\right)$, there was a loss of a hout $1.5 \%$ in electrical out put when modulating valves were used as compared to the case with no valves. For heat loads of $15.8 \times 10^{8} \mathrm{~kJ} / \mathrm{h}\left(15.0 \times 10^{8}\right.$ $\mathrm{Blu} / \mathrm{h}$ ), the additional loss in output ranges from 2.5 to $3.5 \%$ (see Tables A.l and A.2).

Because the valves increased the practical cycle heat load, calculations were made at a heat load of $31.7 \times 10^{8} \mathrm{~kJ} / \mathrm{h}\left(30.0 \times 10^{8} \mathrm{Btu} / \mathrm{h}\right)$.

The back-pressure turbine (with modulating valves) which exhausts to the desalination plant, had a power output that was $85.2 \mathrm{MW}(\mathrm{e})(7.8 \%)$ greater than the output of the HP exhaust extraction cycle for a heat load of $15.8 \times 10^{8} \mathrm{k.I} / \mathrm{h}\left(15.0 \times 10^{8} \mathrm{Rtu} / \mathrm{h}\right)$. The difference in output was $171.4 \mathrm{MW}(\mathrm{c})(17 \%)$ for a heat load of $31.7 \times 10^{8} \mathrm{~kJ} / \mathrm{h}\left(30.0 \times 10^{8} \mathrm{Btu} / \mathrm{h}\right)$.

However, the performance of the back-pressure turbine cycle with modulating valves was much poorer than the multiple LP extraction cycle, $11098.6 \mathrm{MW}(\mathrm{e})$ vs $1117.6 \mathrm{MW}(\mathrm{e})$ at a heat load of $15.8 \mathrm{q} 10^{8}$ $\mathrm{kJ} / \mathrm{h}\left(15.0 \times 10^{8} \mathrm{Btu} / \mathrm{h}\right)$ and $1022.4 \mathrm{MW}(\mathrm{e})$ vs $10607 \mathrm{MW}(\mathrm{e})$ at heat load of $31.7 \times 10^{8} \mathrm{~kJ} / \mathrm{h}\left(30.0 \times 10^{8}\right.$ $\mathrm{Blu} / \mathrm{h}$ ) (see Table A.1).

The cycle, which extracts from a single point (HP exhaust) and sends this steam directly to the desalination process, had the highest loss in output when modulating valves were incorporated. The loss in out put was $80.4 \mathrm{MW}(\mathrm{e}), 161.4 \mathrm{MW}(\mathrm{e})$ and $323.8 \mathrm{MW}(\mathrm{e})$ for heat loads of $7.9 \times 10^{8}, 15.8 \times 10^{8}$ and $31.7 \times 10^{8} \mathrm{~kJ} / \mathrm{h}\left(7.5 \times 10^{8}, 15.0 \times 10^{8}\right.$, and $\left.30.0 \times 10^{8} \mathrm{Btu} / \mathrm{h}\right)$, respectively.

\section{Tuıbine Exlıausi Pressure andi Lòãd Variations}

Calculations were made for all five cycles over a range of turbine ex haust pressures from 5.1 to 27.1 $\mathrm{kPa}(1.5$ to $8.0 \mathrm{in} . \mathrm{HgA})$. So, it is possible to make comparisons at condenser pressures corresponding to once-through, wet or advanced dry cooling systems. These data are shown on Figs. A6 through Al4.

In addition to the calculations at rated flow, calculations were made at maximum throttle flow ( $105 \%$ of rated throttle flow), at $0.80 \%$ of rated throttle flow and at $60 \%$ of rated throttle flow. In these cases the heat load was varied in direct proportion to the change in throttle flow. The curves representing the various cycles are labeled on each figure.

The curves for the base and Zeresh cycles are identified by a circle. 
ORNL-DWG 79-17212 ETD

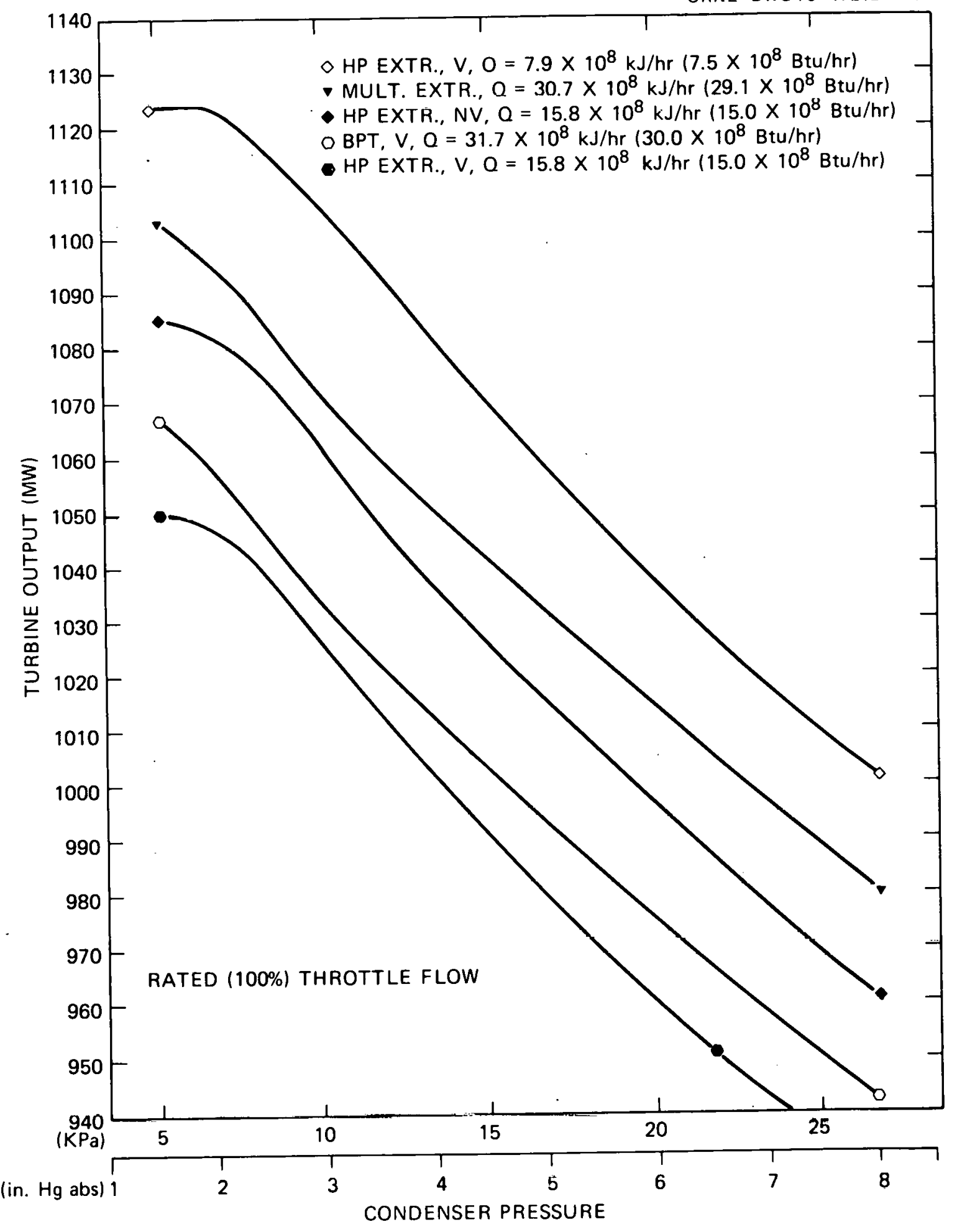

Fig. A6 


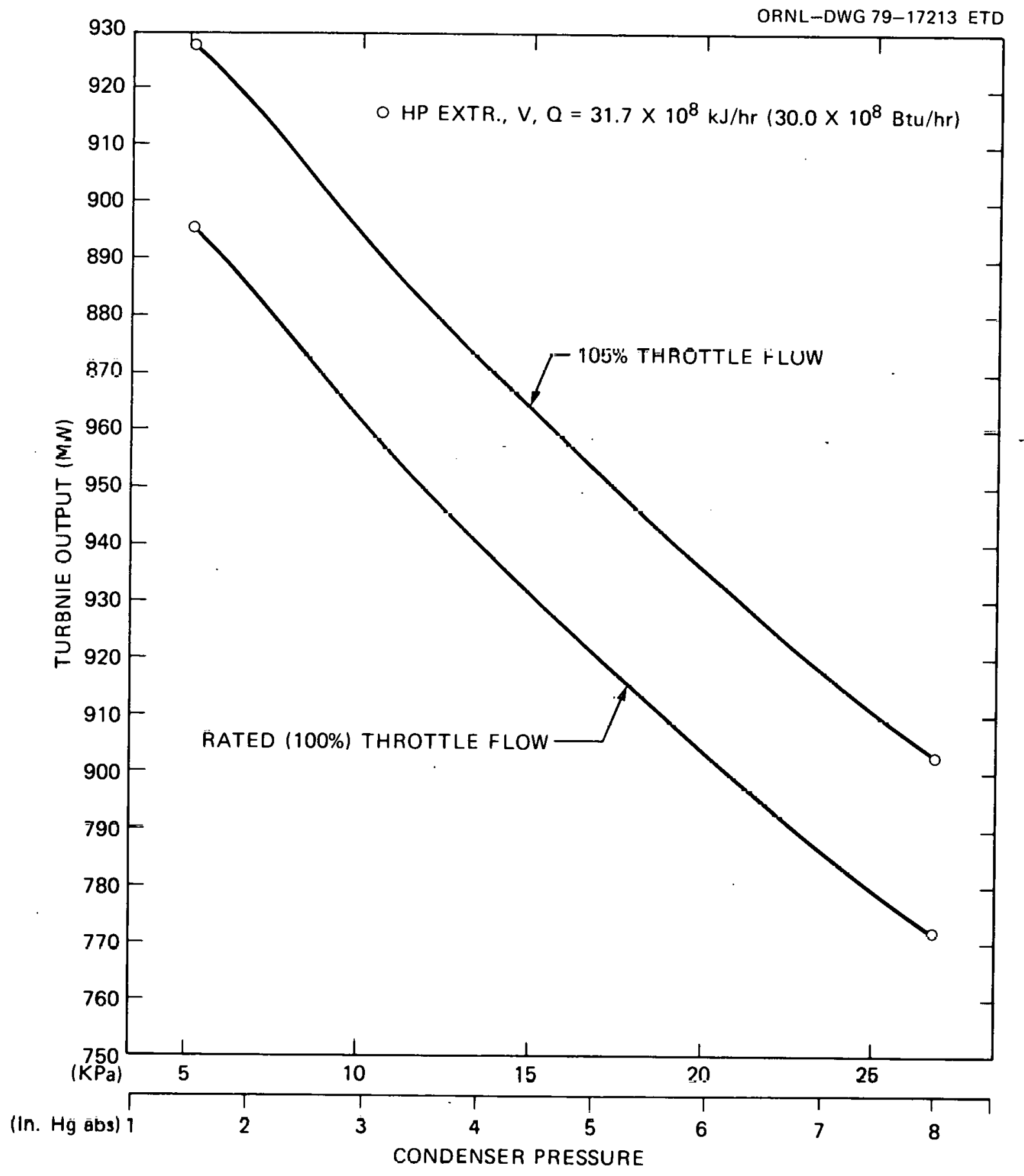

Fig. A7 


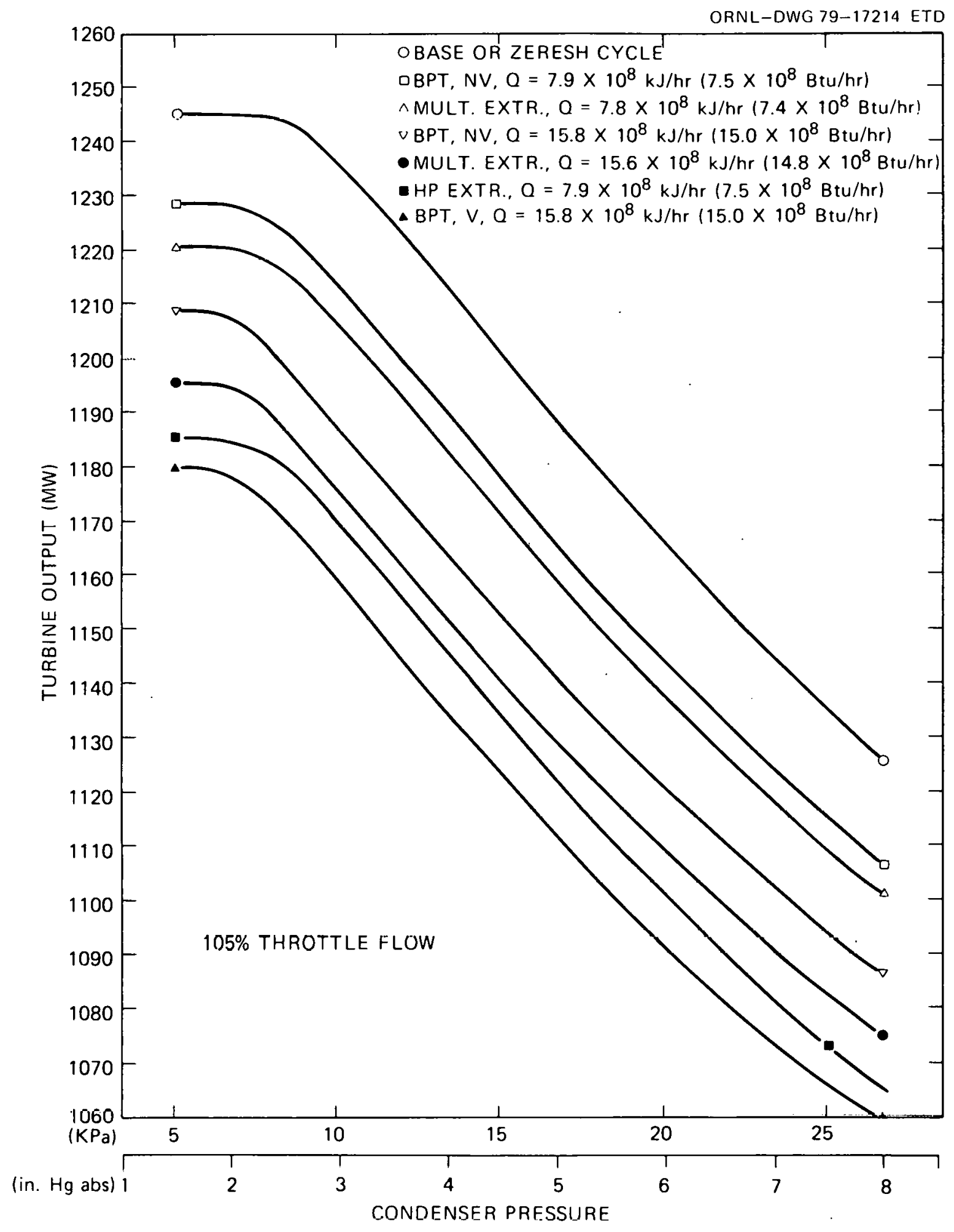

Fig. AR 


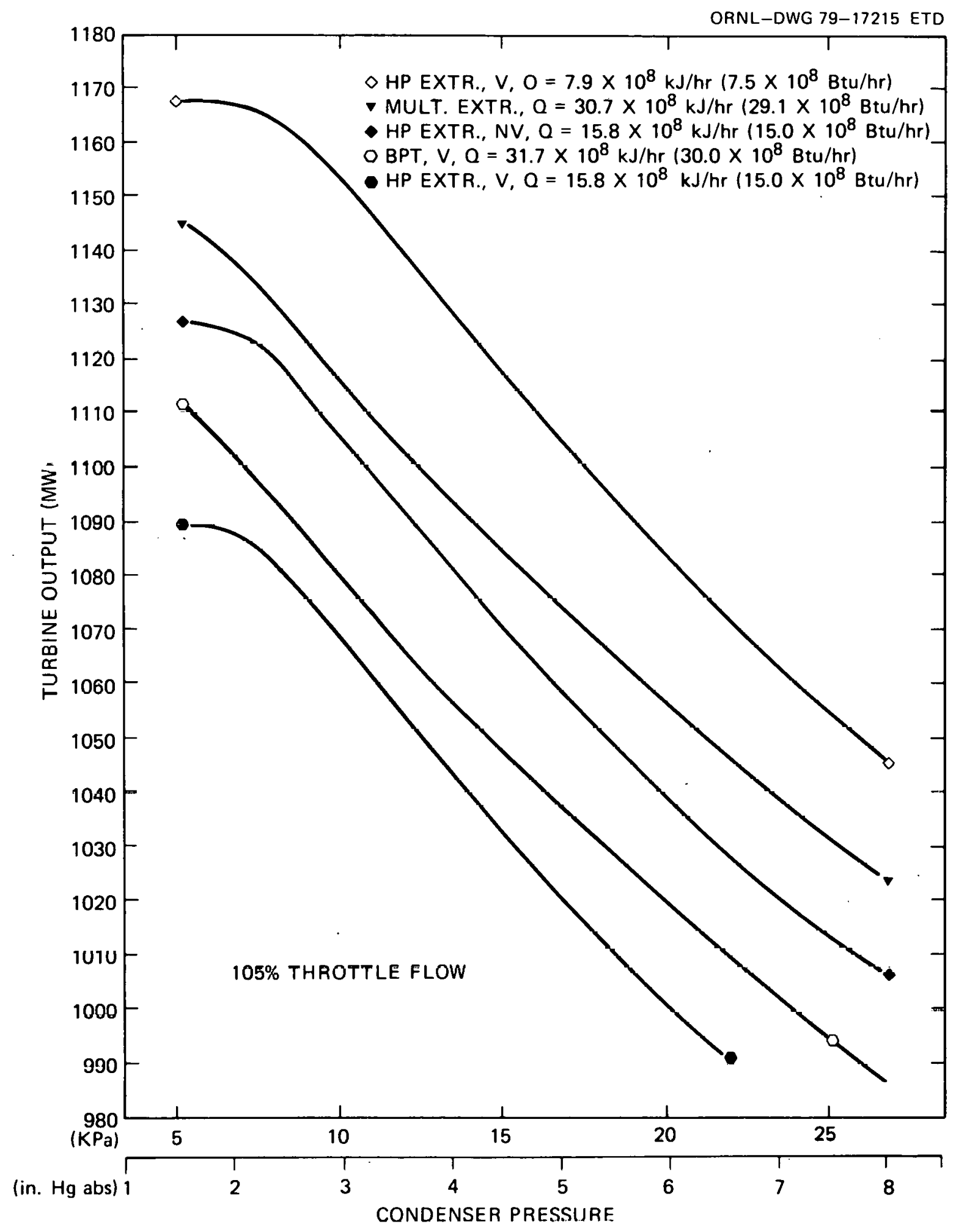

Fig. A9 


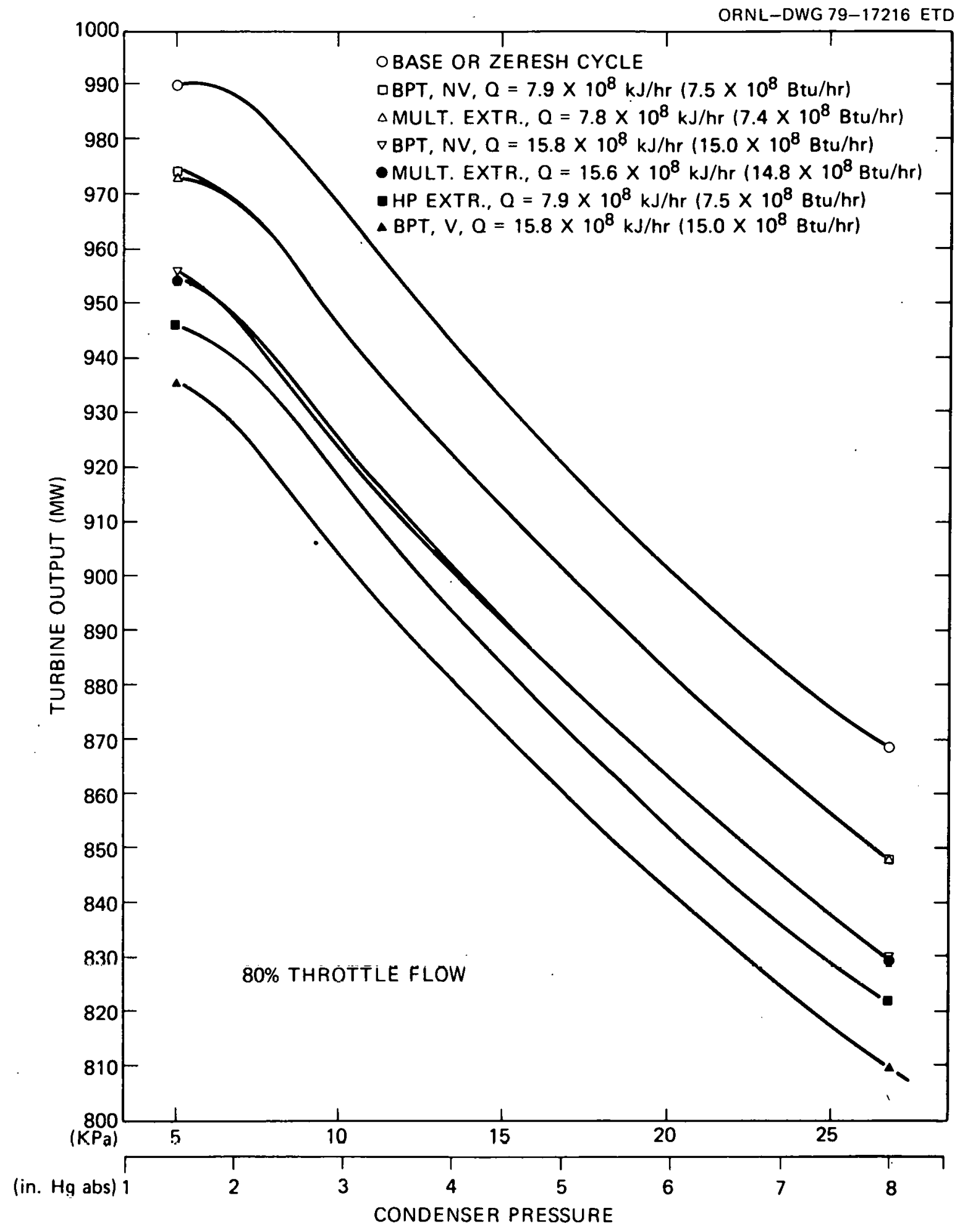

Fig. Alo 


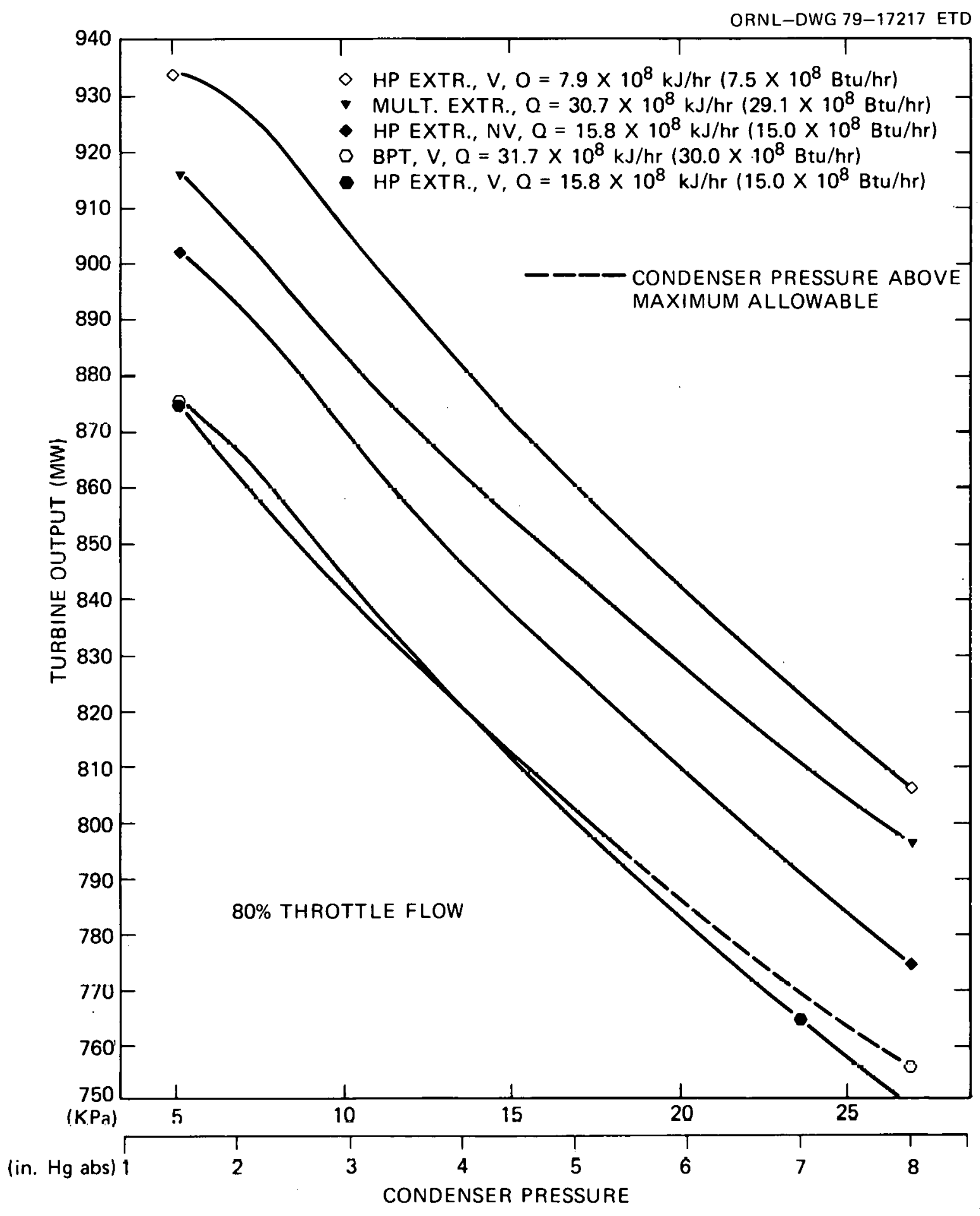

Fig. Al1 


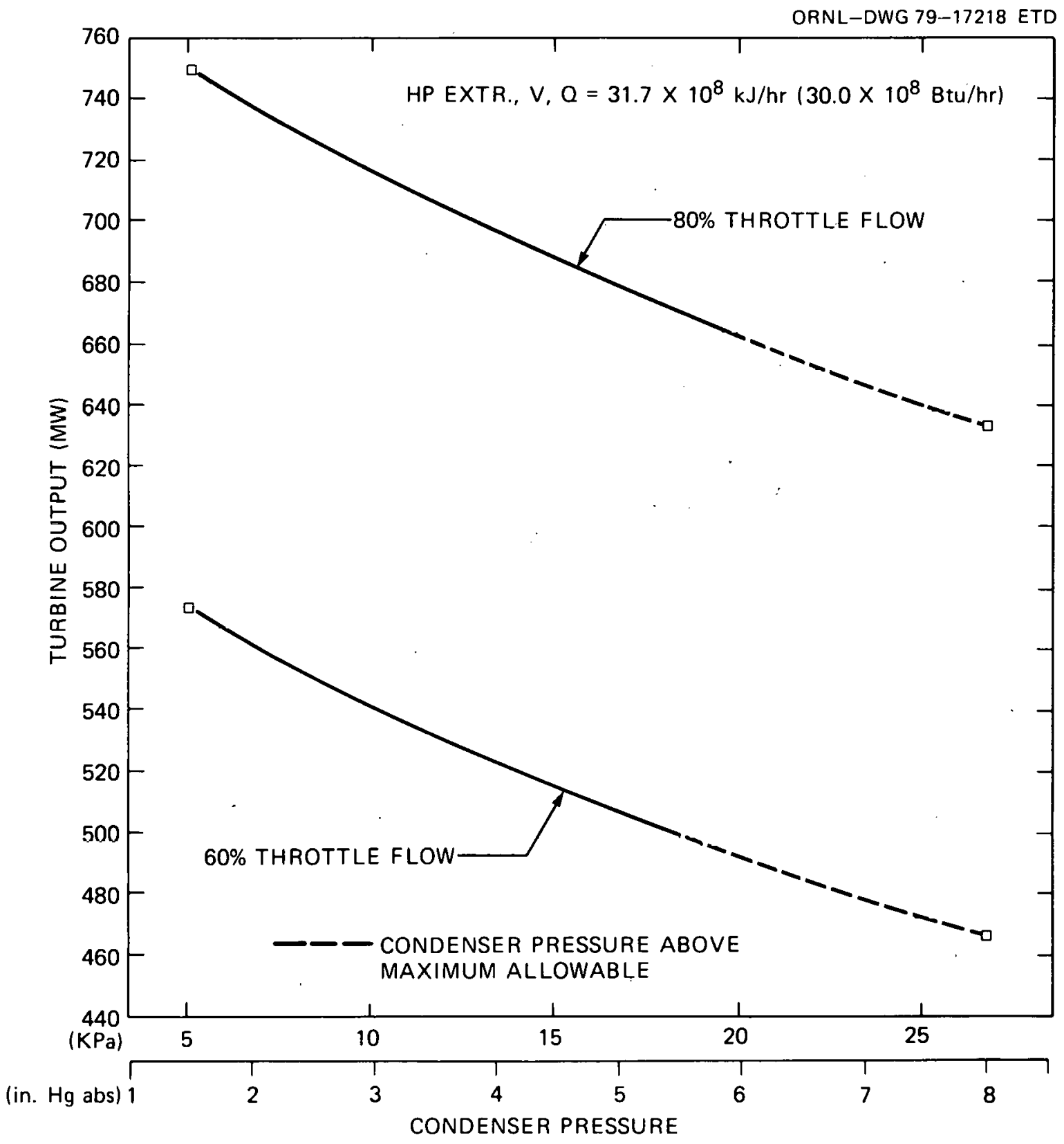

Fig. A12 


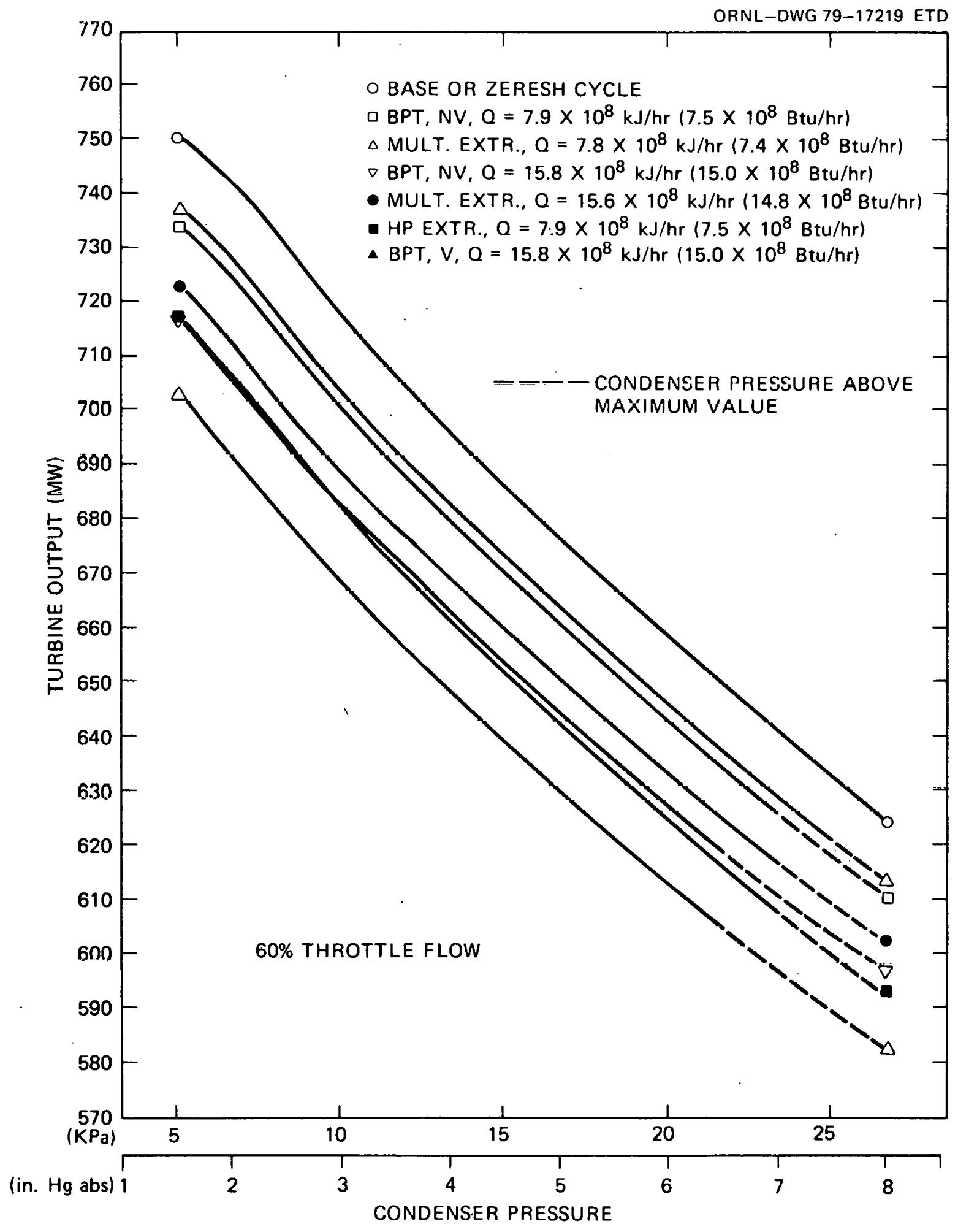

Fig. A13 


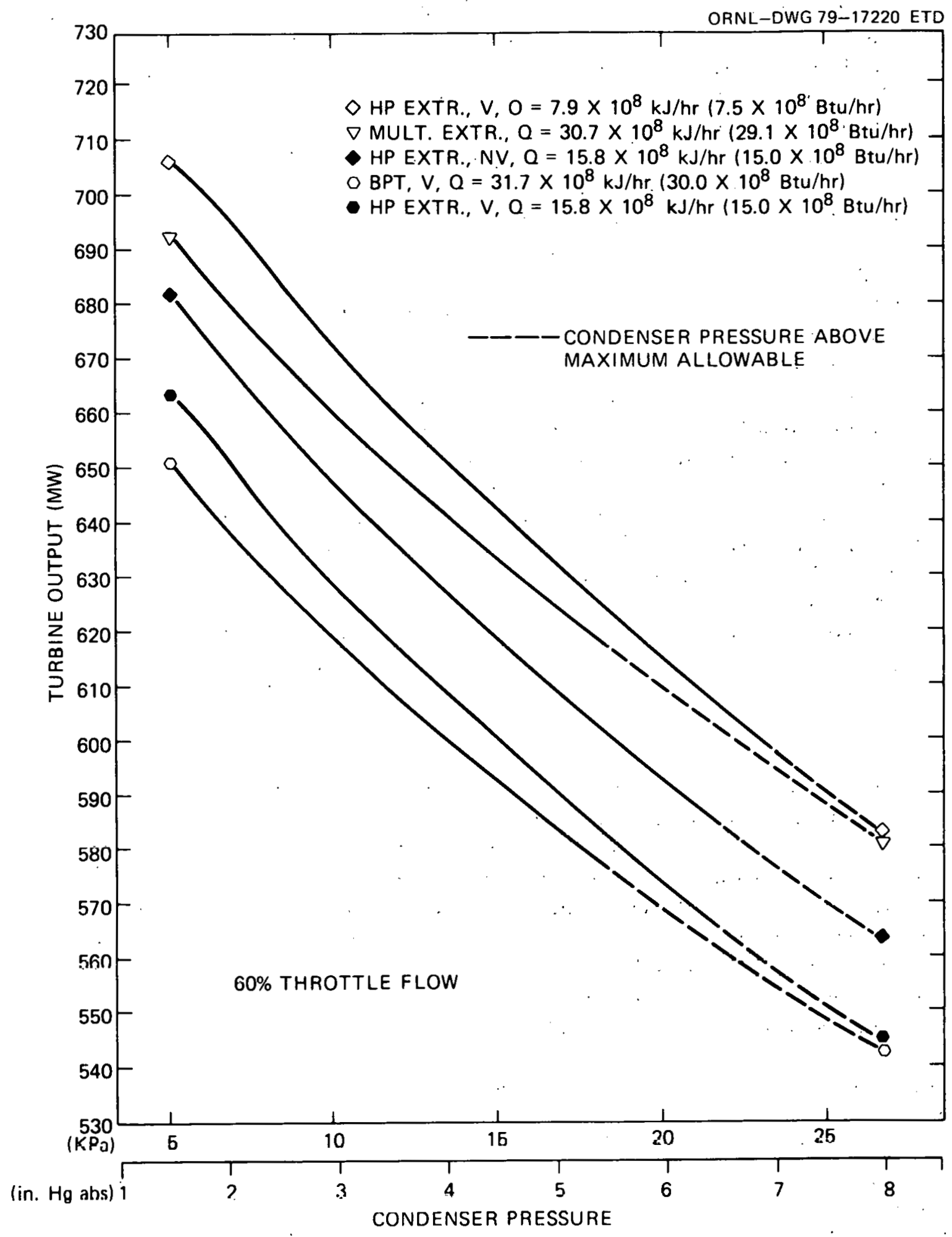

Fig. Al4 
The curves for the HP Exhaust Extraction Cycle without modulating valves are identified by a downward pointing arrow and an inverted tee for heat loads of $7.9 \times 10^{8}$ and $15.8 \times 10^{8} \mathrm{~kJ} / \mathrm{h}\left(7.5 \times 10^{8}\right.$ and $\left.15.0 \times 10^{8} \mathrm{Btu} / \mathrm{h}\right)$, respectively. The labels on the figures are " $\mathrm{HP}$ Extr., $\mathrm{Q}=7.9 \times 10^{\mathrm{R}} \mathrm{kJ} / \mathrm{h}\left(7.5 \times 10^{\mathrm{k}}\right.$ Btu/h)" and "HP Extr., Q $=15.8 \times 10^{8} \mathrm{~kJ} / \mathrm{h}\left(15.0 \times 10^{8} \mathrm{Btu} / \mathrm{h}\right)$."

The curves for the same cycle but with modulating valves are identified by a tee with the tail pointed to the right and a plus sign for heat loads of $15.8 \times 10^{8}$ and $32.6 \times 10^{8} \mathrm{~kJ} / \mathrm{h}\left(15.0 \times 10^{\mathrm{s}}\right.$ and $30.0 \times 10^{\mathrm{B}}$ $\mathrm{Btu} / \mathrm{h})$, respectively. The labels on the figures are "HP Extr., $\mathrm{V}, \mathrm{Q}=15.8 \times 10^{\mathrm{8}} \mathrm{kJ} / \mathrm{h}\left(15.0 \times 10^{\mathrm{8}} \mathrm{Btu} / \mathrm{h}\right)$ " and "HP Extr., V, Q $=31.6 \times 10^{8} \mathrm{~kJ} / \mathrm{h}\left(30.0 \times 10^{8} \mathrm{Btu} / \mathrm{h}\right)$."

The curves for the multiple LP Extraction Cycle are identified by a triangle, an upward pointing arrow and an upright tee for heat loads of $7.8 \times 10^{8}, 15.6 \times 10^{8}$ and $30.7 \times 10^{8} \mathrm{~kJ} / \mathrm{h}\left(7.4 \times 10^{8}, 14.8 \times 10^{8}\right.$ and $\left.29.1 \times 10^{8} \mathrm{Btu} / \mathrm{h}\right)$, respectively. The labels on the figures are "Mult. Extr., $\mathrm{Q}=7.8 \times 10^{\mathrm{x}} \mathrm{kJ} / \mathrm{h}(7.4 \times$ $\left.10^{8} \mathrm{Btu} / \mathrm{h}\right), "$ "Mulc. Extr., $\mathrm{Q}=15.6 \times 10^{8} \mathrm{~kJ} / \mathrm{h}\left(14.8 \times 10^{8} \mathrm{Btu} / \mathrm{h}\right)$ " and "Mult. Extr., $\mathrm{Q}=30.7 \times 10^{8} \mathrm{~kJ} / \mathrm{h}$ $\left(29.1 \times 10^{8} \mathrm{Blu} / \mathrm{h}\right) . "$

I he curves for the High Exhaust Pressure lurbille willoul modulating valves are identified by u square and an inverted triangle for heat loads of $7.9 \times 10^{8}$ and $15.8 \times 10^{8} \mathrm{~kJ} / \mathrm{h}\left(7.5 \times 10^{8}\right.$ and $15.0 \times 10^{\mathrm{x}}$ $\mathrm{Btu} / \mathrm{h})$, respectively. The labels on the figures are "BPT, NV,Q=7.9 $\times 10^{8} \mathrm{~kJ} / \mathrm{h}\left(7.5 \times 10^{8} \mathrm{Btu} / \mathrm{h}\right)$ " and "BPT, NV, $\mathrm{Q}=15.8 \times 10^{8} \mathrm{~kJ} / \mathrm{h}\left(15.0 \times 10^{0} \mathrm{Btu} / \mathrm{h}\right) . "$

The curves for this sa me cycle with modulating valves are identified by an arrow pointing to the left and a tee with the tail pointing to the right for heat loads of $15.8 \times 10^{8}$ and $31.7 \times 10^{\mathrm{x}} \mathrm{kJ} / \mathrm{h}\left(15.0 \times 10^{\mathrm{K}}\right.$ and $\left.30.0 \times 10^{8} \mathrm{Btu} / \mathrm{h}\right)$, respectively. The labels on the figures a re "BPT, $\mathrm{V}, \mathrm{Q}=15.8 \times 10^{\mathrm{g}} \mathrm{kJ} / \mathrm{h}\left(15.0 \times 10^{\mathrm{K}}\right.$ Btu/h)" and "BPT, V,Q $=31.7 \times 10^{8} \mathrm{~kJ} / \mathrm{h}\left(30.0 \times 10^{8} \mathrm{Btu} / \mathrm{h}\right)$.

The portions of the curves that are at condenser pressures above $18.6 \mathrm{kPa}(5.5 \mathrm{in} . \mathrm{HgA})$ and where exhaust flow is below the minimum required value are drawn as dashed lines.

\section{Operating Flexibility}

The "Zeresh Cycle" and the "Multiple LP Extraction Cycle" exhibit the greatest flexibility in regard to operating in both the single- and dual-purpose mode. Considering the probablc nced for modulating valves for the cycle with the back-pressure turbine, the two previously mentioned cycles incur the least loss in plant output in the dual-purpose mode.

Plant output during single-purpose operation of all cycles would be essentially the same as the base cycle with the possible exception of the Zeresh cycle (unless the cooling water can be sent directly to the turbine condenser instead of the desalination apparatus).

Following is a copy of a typical computer printout for a luad puint fur llie desalination study. Some portions of the data have not been included as they contain proprietary data.

This calculation relates to the rated load point of the base cycle. The heat balance program can do several overall types of calculations. For the calculation under discussion, the calculation was made at desired reactor output ( $3425 \mathrm{MW}$ ) which corresponded to rated turbine output. See "kW Thermal" of "Generator, Component No. 1901." In this particular case, throttle flow is varied to obtain the desired reactor power. In addition, the program has a number of convergence checks (1) Is the stage pressure variation from iteration to iteration less than a given value? (2) Is the condenser flow variation (from iteration to iteration) within a predetermined tolerance? and (3) Is the heat rate variation (from iteration to iteration) within a predetermined tolerance? Among the independent variables that may have to be satisfied (depending on the calculation type) are turbine output, heat rate, reactor output, and exhaust flow. 
The computer deck was set up so that it could simulate all five cycles that were investigated by specification of codewords and other input data. For example, "Component Nos. 2617, 2616, 2615, 2614 and 2613 Generalized Heater" are used to simulate the heat exchangers for the cycle which extracts from all of the low pressure turbine extraction points. The heat exchanger with the cycles with the single extraction point at the high pressure turbine exhaust is simulated by "Air Heater or Flash Tank, Component No. 2713." The feed heaters are simulated by "Generalized Heater, Component Nos. 2607, 2606, 2605, 2604, 2603, 2602 and 2601." Component 2610 is simulating a separate drain cooler.

The 1\&A is simulated by "Heat Transfer, Component No. 2201."

The supply points and flow requirements of the various heat exchangers are simulated by "Extraction Point." 
RECURD UP COMYERGENCE

HUMACONYERGENT PARAHETER

cona

THRORTLERLOW

HaA RAPE.

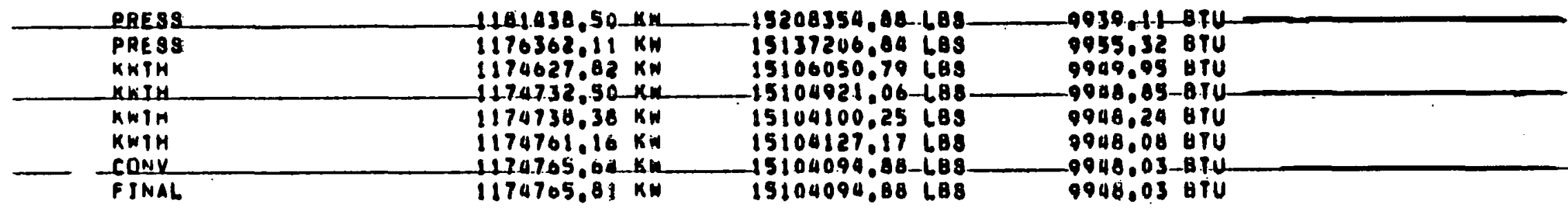

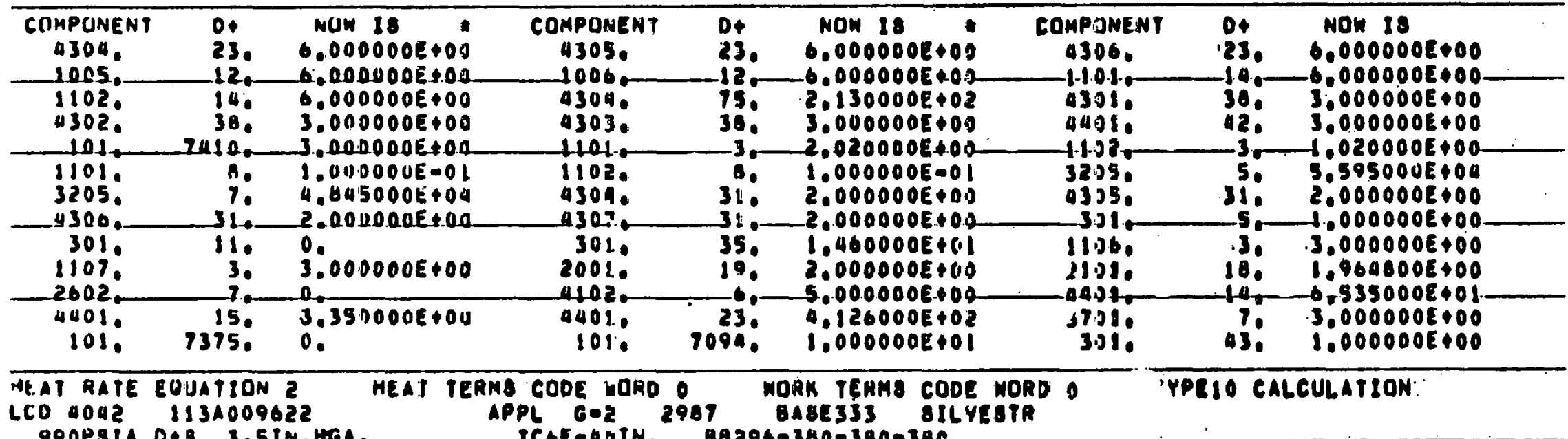

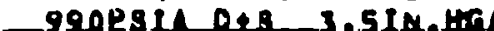

TCoEnADLH $882060380=380=380$

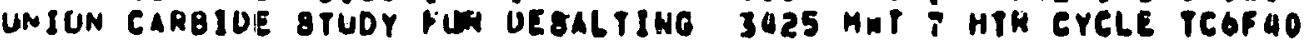

CALCULAUIUN EOR POUNT 2

CALCULAIIUNG USED ASME BTEAM TAGLES

Busler

COMEOMEAR NUABER_LL.

FINAL FW HI $\quad 417.929$ 81 GEM MOISTE

SI TES H2

IMRIIT ENIH a 1191.066 THAOTT FLON

.0025 ST BEN. TENP :

:(!) ILER LOSS

1.06 ATTEMP ENTH

19.200095. DEL_P.86-8T.

1S100095. THACT TEMP

0.000 ATTEMP FLOW:

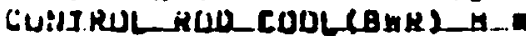

-.00O CCONTROL_RUD_COOL.(BWA) HL

343 3bI BT OEN P2 . $: 990,000$

J J.0000_THRUT_RAEB8_- 960.000

539.651 THKOT MUIST 00041

o. Bteam Tap n

0. 


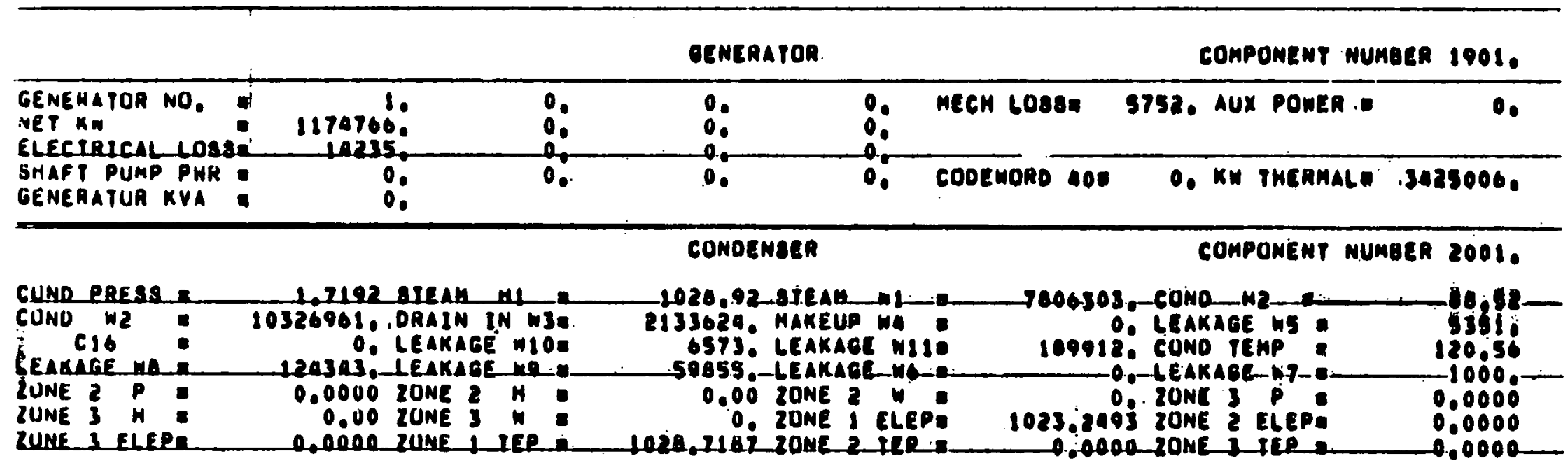

IF 680 . I,MAKEUP IS SIGNAL ONLY.

COAPLEX PUAP

CUMPONENT nUMAER 2120.

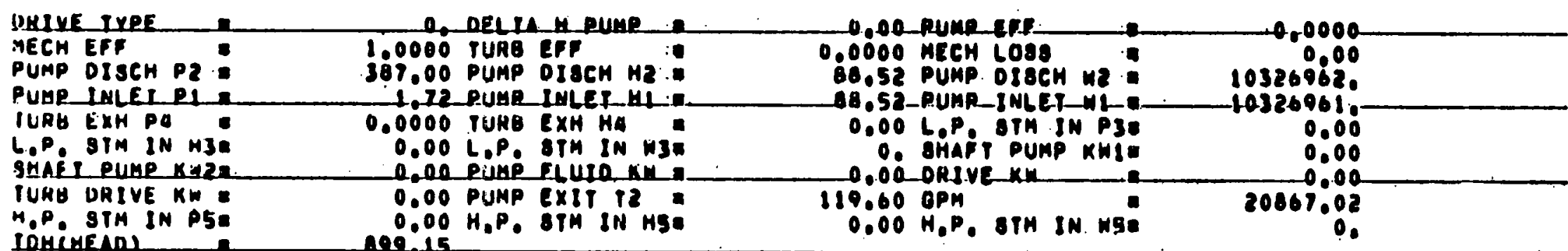

ONIVE IYPE - O FOR MOTOR, I FUR BHAFT, I FOR TURBINE

LeIVE IYPE a 2, DELTA RLUAR

"ECH EFF 1.0000 TURB EPF

PUMP DISCM PZ $\quad 1130.62$ PUMP OISCH HZ

PUAP INLEI PI I 36.0.00 QUAP IMLEI HL

IUAG EXH PA 1.9608 TUAB EXH HA

L.P. STM IN M3E $1279.98 \mathrm{LOP.}$ ITH IN WBA

SHAFI_PUMP_KM2⿴囗_ O 0.00 .PUMP FLUID:KM .

3.13 RUMR etr 7800 NECH LOS8 381.36 PUMP DIOCH W2 15100097. 376.23 RUMP_INLS INL IS100097. 2031.35 b.P. OTM IN P3E 163.01 109912. OHAFT PUMP KMIQ 0.00 $-0.00$ 


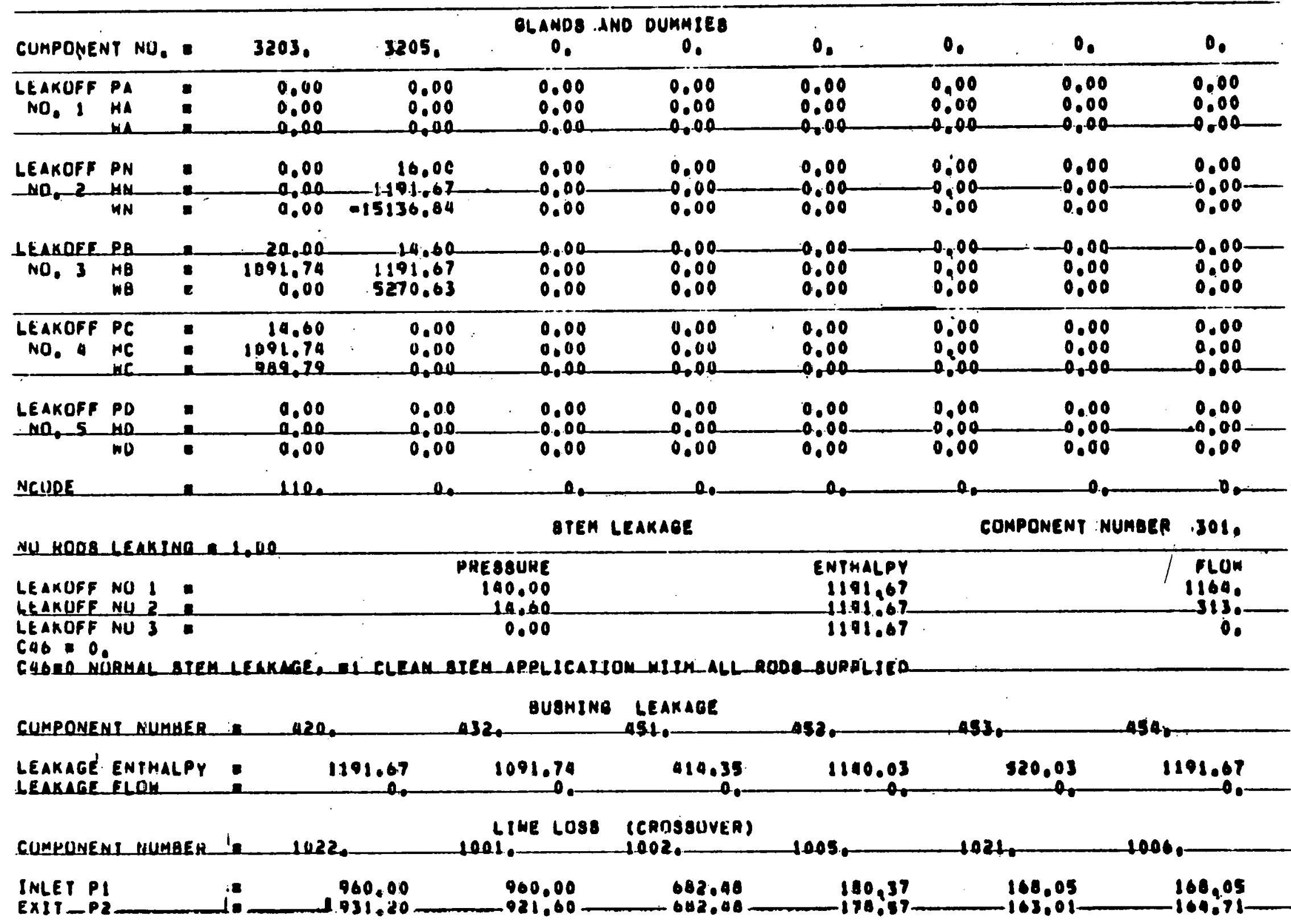




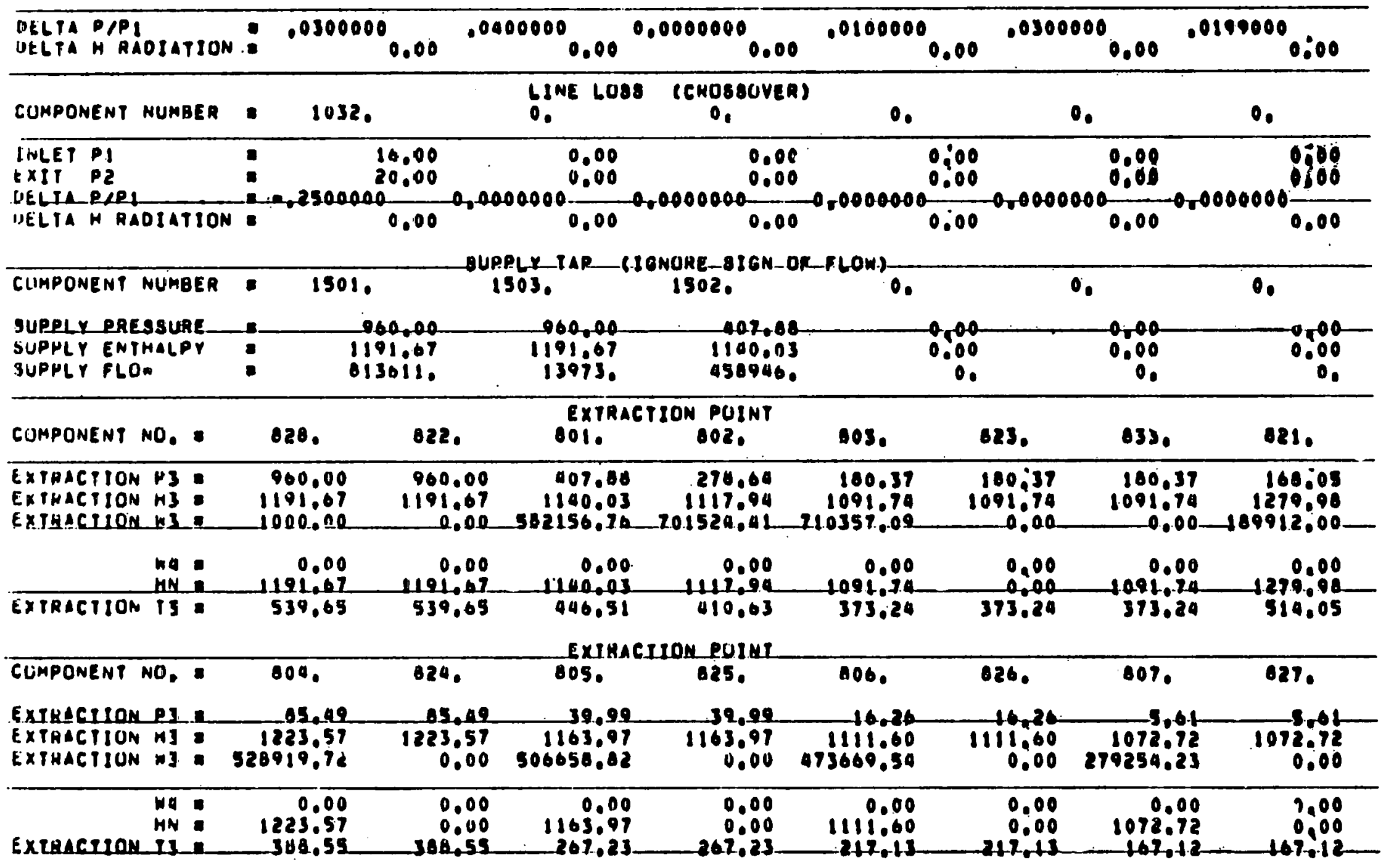




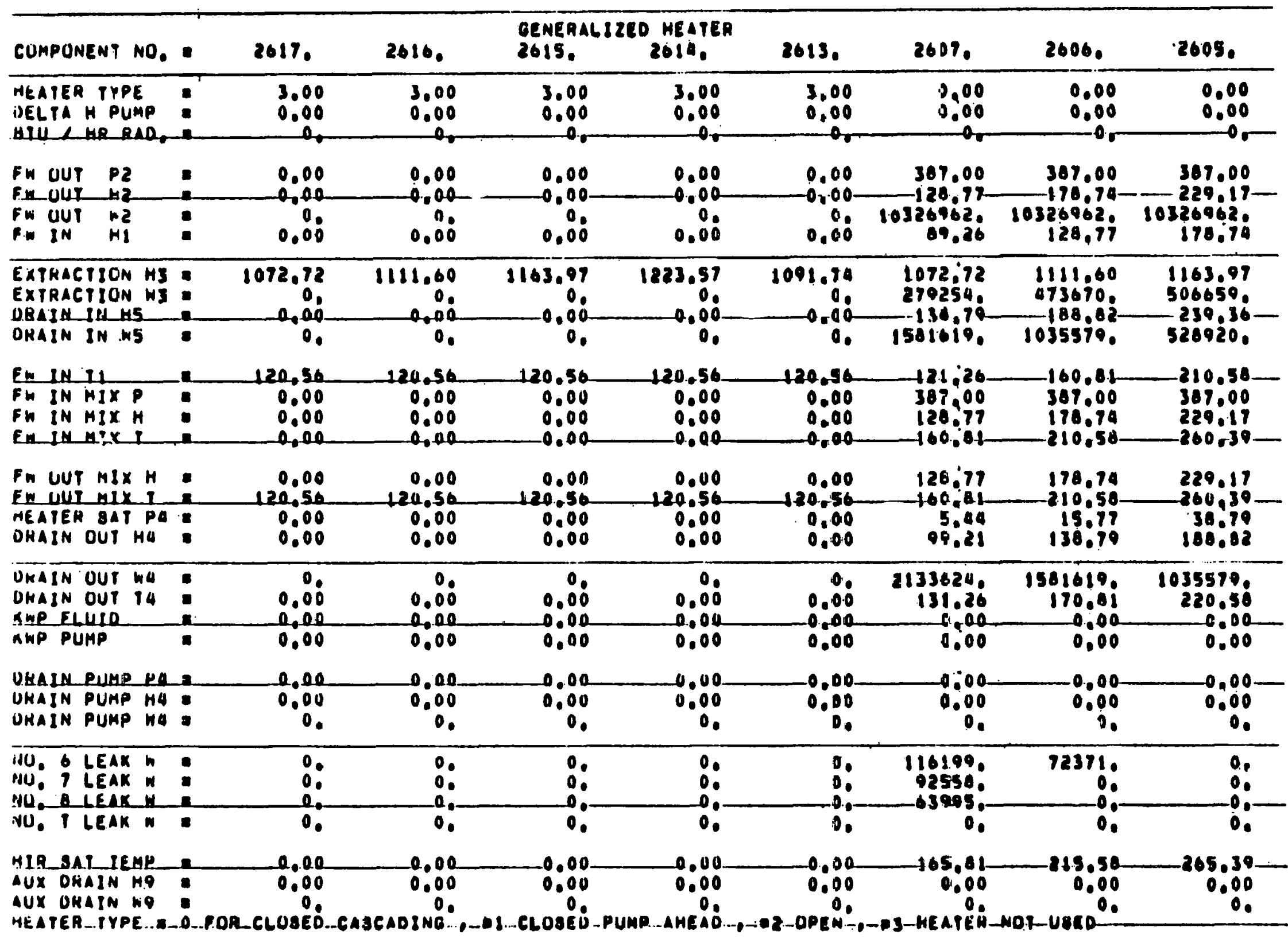




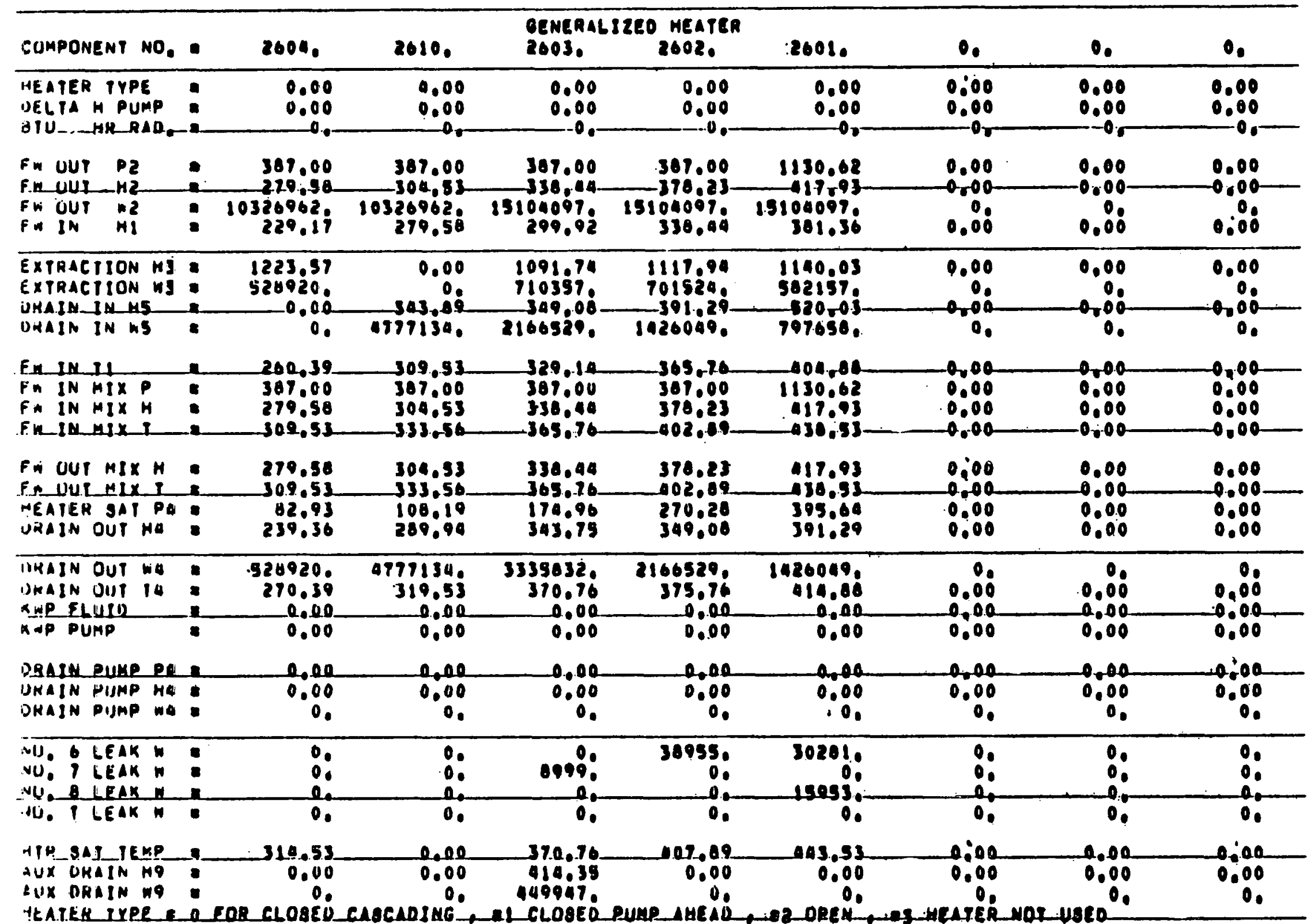




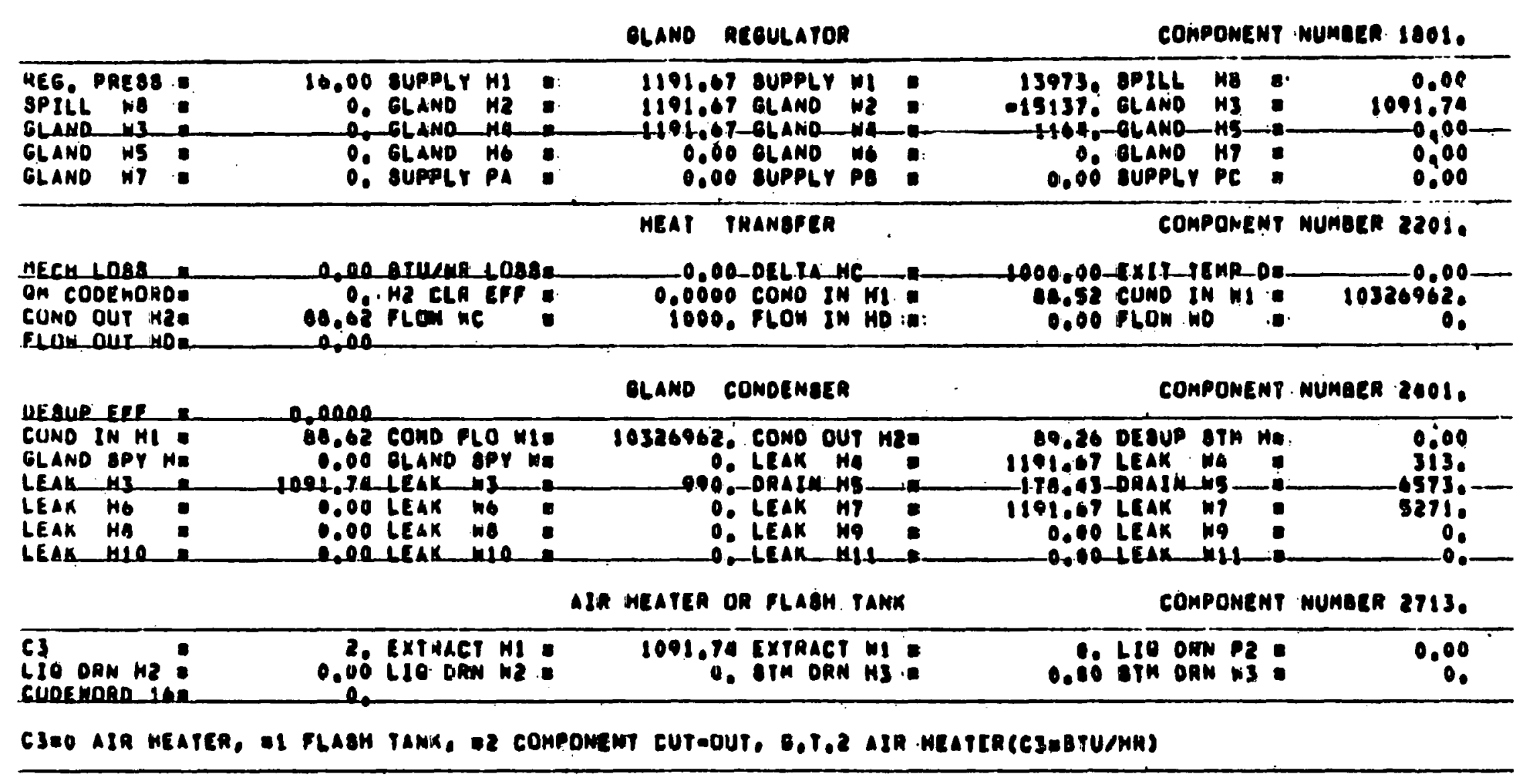




\section{REFERENCES}

1. Guide to the Preparation of Environmental Reports for Nuclear Power Plants, U.S. Atomic Energy Commission, Directorate of Regulatory Standards, August 1972.

2. K. A. Olesen and R. J. Budenholzer, "Economics of Wet/ Dry Cooling Tower Show Progress," Electrical World, Dec. 15, 1972.

3. J. P. Davis, "The Regulation of the Environmental Effects of Nuclear Power Plants," Nucl. Safety 14(3), 165-81 (May- June 1973).

1. Utility Staffing and Training for Nuclear Power, WASH-1130 (Rev.).

5 T. R. Silson, M. S. Hildreth, Jr., and G. C. Gower, Evaluation of Nuclear Power Plant Availability, OOE-ES-001 (January 1974).

6. W. G. Sullivan et. al., Reliability Estimation for Multiunit Nuclear and Fossil-Fired Industrial Energy Systems, ORNL/TM-5837, August 1977.

7. Meeting the Challenge to Nuclear Energy Head-On, Remarks by William O. Doub, Commissioner, U.S. Atomic Energy Commission, Atomic Industrial Forum Annual Conf., San Francisco, Calif., Nov. 12, 1973.

8. Desalting Handbook for Planners, U.S. Department of the Interior, Office of Saline Water and the Bureau of Reclamation, 1st ed. (1972).

9. E. C. Hise et al., Conceptual Design Study of a 250-Million Gallons Per Day.Combined Vertical Tube-Flash Evaporator Desalination Plant (Oak Ridge National Laboratory), Office of Saline Water Research and Development Report, No. 391 (PB 206350) (1978).

10. A. Z. Barak, L. Awerbuck, and R. H. Horowitz, Proc. of the Internal. Congress on Desalination and Water Reuse (Tokyo, Japan), 2:553-561 (1977).

11. A. Z. Barak, Proc. of the First Desalination Congress of the American Continent, 2:VII-4, 1-10, Mexico City (1976).

12. Press conference, Ciba-Giegy Plastics \& Additives Co., 30 Buckingham Gate, London, Oct. 14, 1976, Presentation by S. Smith, A. J. Maltpress, and A. Harris.

13. F. C. Wood et al., "The Hong Kong 40 MGD Desalination Plant-Its Design Features and Performance during the First Year of Operation," in Proceedings of the First Desalination Congress of the American Continent, Vol. II IX-1, pp. 1-15 (1976).

14. Office of Saline Water, R\&D Progress Report No. 668, pp. 23-41, 51-58 (April 1971).

15. Office of Saline Water, K\&D Progress Report No. 668, pp. 269-320 (A pril 1971).

16. Office of Saline Water, R\&D Progress Report No. 977, pp. 87, 137-153 (May 1974),

17. Office of Saline Water, R\&D Progress Report No. 57 (February 1962).

18. Office of Saline Water, R\&D Progress Report No. 964 (January 197l).

19. W. F. Mcllhenny, Sea Water Softening by Ion Exchange as a Saline Water Pretreatment, PB-181298, Saline Water Research and Development Report No. 62, Dow Chemical Company (May 1962).

20. W. F. Mcllhenny, "Minimizing Scale Formation in Saline Water Evaporators," in Saline Water Conversion, II. Advanced in Chemistry, Series 38, American Chemical Society, Washington, D.C. (1963).

21. Gerhard Klein et al., "Ion Exchange Equilibrium Data in the Design of a Cyclic Sea Water Softening Process," I and EC Process Design and Development, 3(3) (July 1964).

22. An Engineering Evaluation of the Long Tube Vertical, Falling Film Distillation Process, Saline Water Research and Development Report No. 139, Dow Chcmical Company, Texas Division (February 1965). 
23. W. F. Mcllhenny and A. B. Baker, U.S. Patent No. 3,056,65I (1958).

24. W. F. Mcllhenny, A. B. Baker, and J. A. Clarke, U.S. Patent No. 2,772,143 (1956).

25. R. J. Staffa and L. Mayfield, Texas Gulf Sulfur Company, U.S. Patent No. 3,026,26I (March 1962).

26. A. Bolognini et al., "Desalination Plant of $3.8 \mathrm{MGD}$ at Gela (Sicily)," I.D.E.A. Conference Proceedings, Mexico City. October 1976.

27. R. C. Roe and D. F. Othmer, "Controlled Flash Evaporation, an Improved Multi-Stage Flash System," in Proceedings of the Third International Symposium on Fresh Water from the Sea. Athens, 1970.

28. Research on Pumping Unit Studies Final Evaluation Report, Office of Saline Water-R\&D Progress Report No. 205 (September 1966).

29. Desalination Materials Manual-prepared by Dow Chemical Company for Office of Water Research and Technology (May 1975).

30. D. Barba et al., "Design and Operational Experience with Long-Tube Acid-Dosed and Cross-Tube Polyphosphate Feed MSF Plants," I.D.E.A. Conference Proceedings, Mexico City, October 1976 .

31. F. C. Wood et al., "The Hong Kong 40 Mgd Desalination Plant-Its Design Features and Performance during the First Year of Operation," in Proceedings First Desalinution Cungress of the American Continent, Vol. 2, Paper IX, 1976.

32. J. C. Deronzier et al., "Usine de distillation de l'can de mer par detente etagee (M.S.F.) de disposition verticale en spirale," in Proceedings of the Fourth International Symposium on Fresh Water from the Sea, Athens, 1973.

33. Desalination of Sea Water Evaporator Plants, Union Carbide Corporation, Nuclear Division, Report No. K-D-1780 (May 1963).

34. Applied Research and Engineering, Ltd. Conceptual Design of a 50-Mgd Desalination Plant, PB245885 (November 1965).

35. Technology Services, Inc., Summary Evaluation of Conceptual Designs for a 50-MGD Desalination Plant, Office of Saline Water Research and Development No. $2 \overline{7} \overline{7}$ (PB 207018), August 1978.

36. L. Awerbuch et al, Joint United States-Israel Desalination Project, Procd. Fifth Annual Conference of the NWSIA, San Diego, California (July 17-21, 1977).

37. I. E. Jones, Jr., T. D. Anderson, and S. A. Reed, Coupling Tecilnology for Dual-Purpose Nuclear Desalting Plants, ORNL/TM-4471 (November 1976).

38. J. E. Jones, Jr. and Truman D. Anderson, A Proposed Lual-Purpose Nuclear Desalting Plant Using Single-Effect Distillation, OR NL/TM-2964 (May 1970).

39. J. E. Jones, Jr., A Dual-Purpose Nuclear Desalting Plant Using a Low-Temperature Evaporator, ORNL/TM-4289 (September 1973).

40. "Technical and Lconomical Fcasibility Study of Combining 'Standard' Nuclear Puwci" Stations with Desalination Plants of the Zeresh Multi Effect Distillation Type" report by the Atomic Energy Commission, Sub Committee for Power and Water, Tel-Aviv, Israel, July 1976.

41. A. Ophir and G. J. Silvestri, "Coupling Westinghouse Standard' Nuclear Turbines with the I.D.E. 'Zeresh' Desalination Plants," May 1977. 
ORNL/TM-7190

\section{Internal Distribution}

I. T. D. Anderson

2. S. J. Ball

3. D. F. Cope

4. W. B. Cottrell

5. R. F. Hibbs

6. R. E. MacPherson

7. J. W. Michel

8. J. S. Johnson

9. J. E. Jones

10. H. Postma

11-73. S. A. Reed
74. J. L. Rich

75. M. W. Roscnthat

76. R. L. Rudman

77. I. Spiewak

78. H. E. Trammell

79. D. B. Trauger

80. ORNL Patent Office

81. Central Research Library

82. Document Reference Section

83-84. Laboratory Records Department

85. Laboratory Records, RC

\section{External Distribution}

86-90. Acting Chief, Advanced Isotope Separation Division, Office of Advanced Nuclear Systems and Projects, Office of Nuclear Energy, DOE, Washington, D.C. 20545

91. James T. Callahan, Catalytic, Inc., 1500 Market Street, Philadelphia, PA 19102

92. Robert H. Evans, Deputy Director, Burns \& Roe Industrial Corp., Washington Operations, $1850 \mathrm{~K}$. Street, NW, Washington, DC 20006

93. Joseph Finke, Kaiser Engineers, Inc., 23210, 300 Lakeside Drive, Oakland, CA 94623

94-95. Wilfred J. Hahn, Asst. Director (Acting) for Technology Development, Office of Water Research and Technology, U.S. Department of the Interior, Washington, D.C. 20240

96. Lee Kindley, Liaison Officer, U.S./Saudi Arabia Joint Program in Desalination, Office of Water Research and Technology, U.S. Department of the Interior, Washington, D.C. 20240

97. Sherman C. May, Process Technology Department, Research and Engineering, Bechtel Corporation, Fifty Beale Street, San Francisco, CA 94119

98. Manual Morris, Deputy Director, Office of Water Research and Technology, U.S. Department of the Interior, Washington, D.C. 20240

99. D. M. Soboroff, Liaison Officer, U.S./Israel Desalination Project, Office of Water Research and Technology, U.S. Department of the Interior, Washingt on, D.C. 20240

100. Office of Assistant Manager for Energy Research and Development, DOE, ORO, Oak Ridge, TN 37830

101-127. Technical Information Center, DOE, ORO, Oak Ridge, TN 37830 